\title{
DESIGN, CONSTRUCTION AND EVALUATION OF \\ AN EXPERIMENTAL CERAMIC MEMBRANE FACILITY \\ WITH INVESTIGATION INTO FOULING CONTROL
}

by

Sarah Shim

B.Eng, Ryerson University, 2007

A thesis

presented to Ryerson University

in partial fulfillment of the

requirements for the degree of

Master of Applied Science

in the Program of

Chemical Engineering

Toronto, Ontario, Canada, 2010

(C) Sarah Shim 2010 


\section{AUTHOR'S DECLARATION}

I hereby declare that I am the sole author of this thesis or dissertation.

I authorize Ryerson University to lend this thesis or dissertation to other institutions or individuals for the purpose of scholarly research.

I further authorize Ryerson University to reproduce this thesis or dissertation by photocopying or by other means, in total or in part, at the request of other institutions or individuals for the purpose of scholarly research. 


\title{
ABSTRACT
}

\section{Design, Construction and Evaluation of an Experimental Ceramic Membrane Facility with Investigation into Fouling Control}

\author{
M.A.Sc., October 2010
}

Sarah Shim

Chemical Engineering

Ryerson University

During the past decade, the growth in membrane research and technology has advanced and multiplied in usage for many industries including water and wastewater. A major limitation of the application is due to membrane fouling.

In this work, the construction, start-up calibration and testing of a membrane unit, as well as an examination into the fouling and cleaning aspect of the ceramic membranes are investigated. An aqueous solution containing precipitate is fed to the unit in order to observe fouling behaviour. Effluent wastewater from a bioreactor, CUBEN, is also tested with the unit and membrane cleaning is performed using various chemical agents. For both chemically enhanced backwash (CEB) and membrane soaking, hydrochloric acid cleaning agent $(<1 \% \mathrm{w})$ produces best flux recoveries of $72.7 \%$ and $82 \%$, respectively. All permeate effluent analysis, resulted in a suspended solids concentration $<3 \mathrm{mg} / \mathrm{L}$ and turbidities $<1 \mathrm{NTU}$, which both meet Ontario regulation limits. 


\section{ACKNOWLEDGEMENTS}

I would like to express my deepest gratitude to my supervisor, Dr. Manuel Alvarez-Cuenca for his endless guidance, knowledge, enthusiasm, and constructive criticism bringing about a sense of direction and insight through my thesis study. Thank you to my co-supervisor Dr. Huu Doan for his encouragement and support which will be remembered and cherished. Many thanks to them for their willingness to help and in advising me in my intellectual and professional pursuit and also for their dedication to provide a stimulating environment for advanced education and research in our department and university. Wherever I go in my future, I will always remember them as respectable mentors.

I would like to acknowledge the professors Dr. Farhad Ein-Mozaffari, Dr. Philip Chan and Dr. ChilHung Cheng who graciously served on my committee.

Special thanks to Mr. Ali Hemmati, Mr. Tondar Tajrobehkar and Mr. Daniel Boothe who were continuously able and always willing to support my demands. It was a very pleasant experience to work with them and I learnt a lot from them.

Many thanks is given to my Ryerson colleagues. I appreciate your support and enjoyed the talks with all of you. Thank you for sharing good moments with me and value our friendship.

Finally, a most sincere acknowledgment to my parents, who have devoted their life to raise, take care, and educate me. They have always served as an example of dedication and hard work. Thanks given to my family for their support, understanding and encouragement. 


\section{TABLE OF CONTENTS}

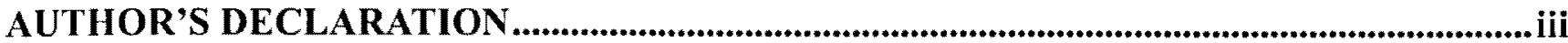

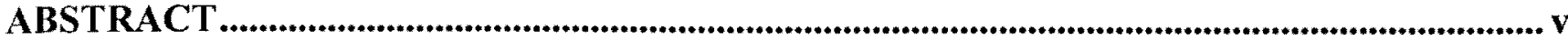

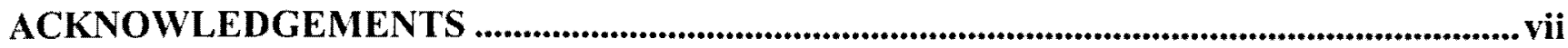

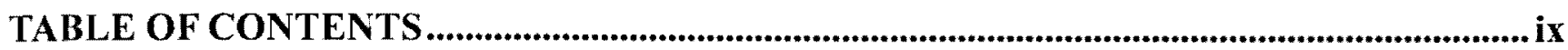

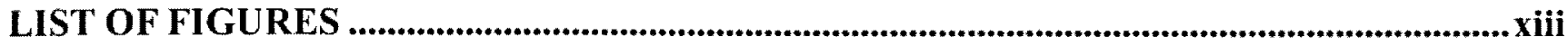

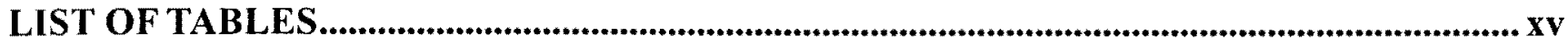

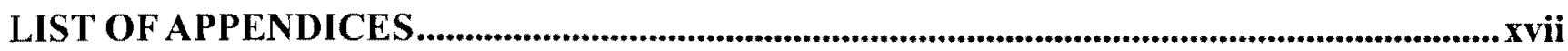

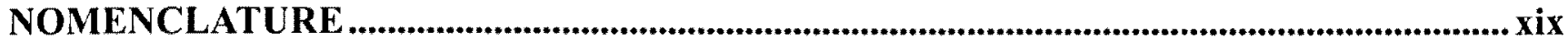

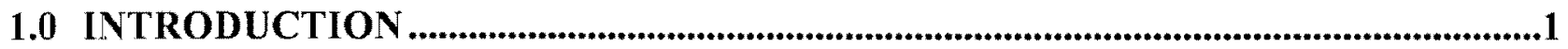

1.1 Introduction to the Problem Definition .................................................................................1

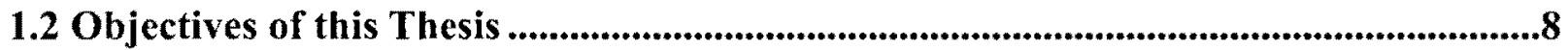

2.0 CONSTITUENTS AND TREATMENT TECHNOLOGIES .........................................11

3.0 MEMBRANE FILTRATION AND TECHNOLOGY …......................................................17

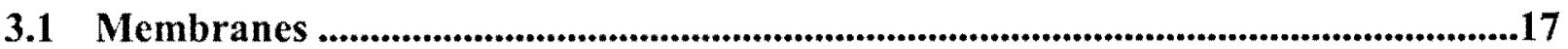

3.1.1 Classification of Membrane Processes ............................................................................17

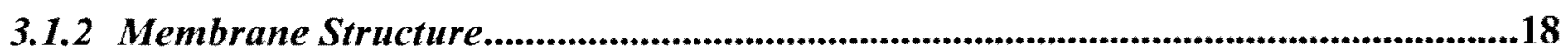

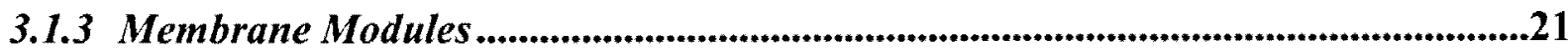

3.1.4 Membrane Materials ..........................................................................................................23

3.1.5 Theory of Filtration and Separation ...........................................................................25

3.2 Membrane Technology Application ..............................................................................29

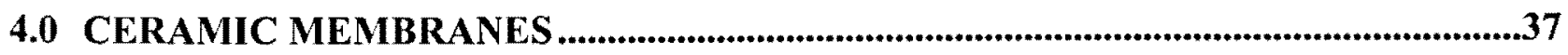

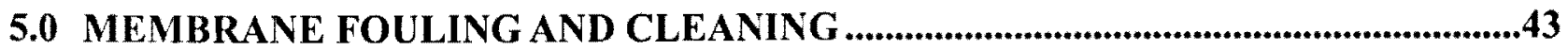

5.1 Membrane Fouling and Concentration Polarization .........................................................43

5.2 Membrane and Foulant Interactions .......................................................................54

5.3 Membrane Cleaning Methods and Example Applications ..........................................56 


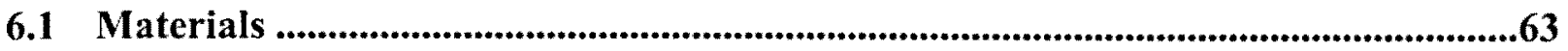

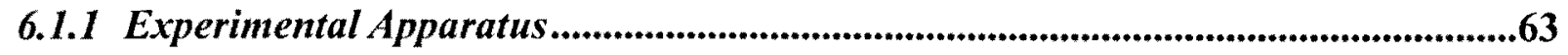

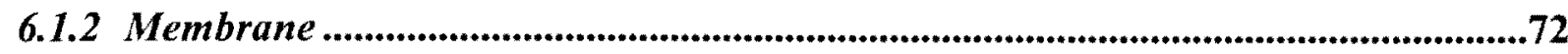

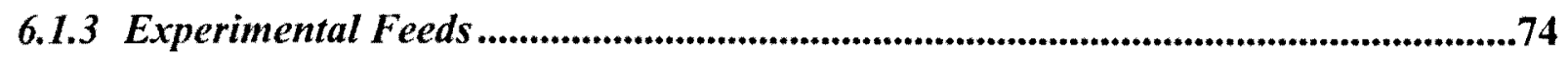

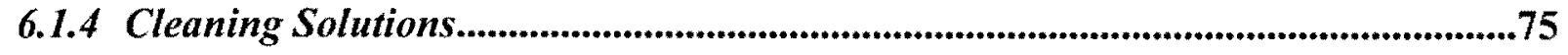

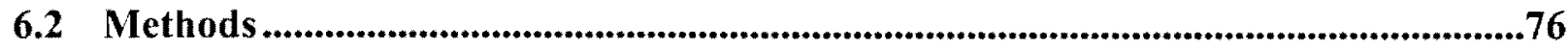

6.2.1 Pure Water Flux Test (Membrane Permeability Determination).............................79

6.2.2 Filtration Trials with Water and Aqueous Solution Feed .....................................81

6.2.3 Filtration, Fouling and Cleaning Trials with Aqueous Solution as Feed .................83

6.2.4 Filtration, Fouling and Cleaning Trials with Wastewater Feed..............................84

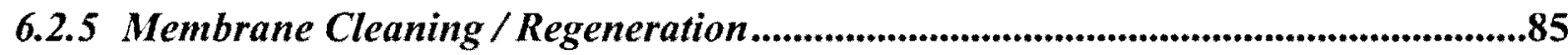

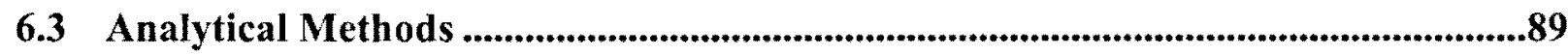

7.0 EXPERIMENTAL RESULTS AND DISCUSSION .................................................95

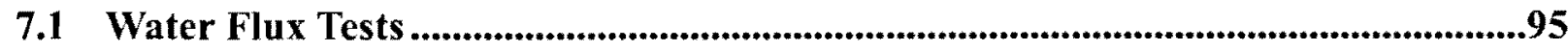

7.2 Membrane Filtration of the Aqueous Solution ...........................................................97

7.3 Filtration of the Aqueous Solution with Membrane Cleaning .................................105

7.4 Filtration of CUBEN Feed with Membrane Cleaning ...........................................108

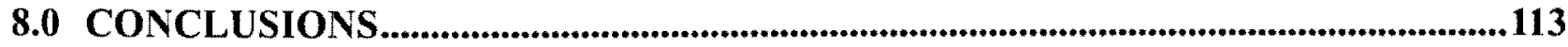

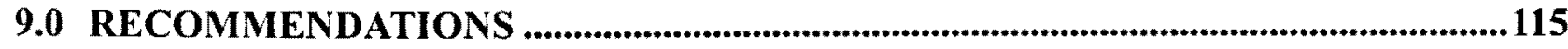

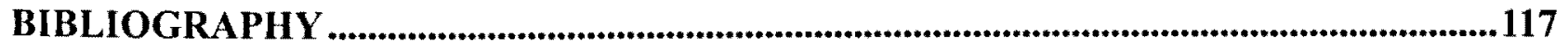

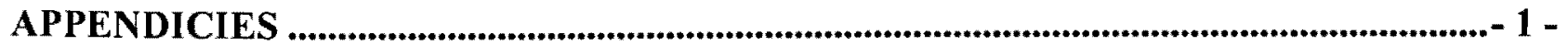




\section{LIST OF FIGURES}

Figure 1.1 Timeline of establishments for ceramic membranes 3

Figure 1.2 Factors influencing the market 5

$\begin{array}{lr}\text { Figure 1.3 Factors affecting membrane filtration } & 6\end{array}$

Figure 2.1 Typical residual constituents found in wastewater effluents 11

$\begin{array}{ll}\text { Figure 3.1 A diagram illustrating various membrane structures } & 19\end{array}$

Figure 3.2 Typical types of membrane modules showing the direction of liquid flow 21

Figure 3.3 Schematic representations of the various membrane modules 22

Figure 3.4 Process configurations of two different membrane treatment trains 29

Figure 3.5 MBR configurations 31

Figure 3.6 Distribution of studies on submerged and external membrane bioreactors 31

Figure 3.7 Configurations of filtration mode $\quad 32$

Figure 3.8 Comparison of flux rates and particle boundary layer thickness 32

Figure 3.9 Representation of flux versus transmembrane pressure for membrane filtration $\quad 34$

Figure 5.1 Concentration Polarization Layer 45

Figure 5.2 Schematic illustration of filtration with concern to membrane fouling 48

Figure 5.3 Fouling mechanisms of porous membranes $\quad 50$

Figure 5.4 Permeate flux of the membrane with or without ultrasound 59

Figure 6.1 Diagram of the ceramic membrane filtration apparatus 65

$\begin{array}{ll}\text { Figure 6.2 Set-up of the ceramic membrane unit and CUBEN bioreactor } & 67\end{array}$

Figure 6.3 Photo of the ceramic membrane filtration apparatus and data acquisition $\quad 71$

Figure 6.4 Photograph of the ceramic membranes filtration unit 73

Figure 6.5 SEM image of the ceramic membrane cross section 73 
Figure 6.6 Brief depiction of the experimental procedure

Figure 6.7 Flow diagram of the membrane filtration unit with two parallel streams

Figure 6.8 Diagram of ceramic tubular membrane module for filtration mode operation

Figure 6.9 Diagram of ceramic tubular membrane module for backwash cleaning

Figure 6.10 Temperature and $\mathrm{pH}$ sensor connected to the data acquisition system

Figure 6.11 DR 2700 spectrophotometer

Figure 6.12 VWR $B$ Model 800 Turbidity Meter Turbidimeter

Figure 6.13 Rame-Hart Instrument for contact angle analysis

Figure 6.14 Malvern Mastersizer 2000 particle size analyzer

Figure 6.15 SEM and EDS analyzer equipment

Figure 6.16 Photo of the ceramic broken pieces used to fit into the SEM

Figure 6.17 SEM image of the ceramic membrane cross-section

Figure 7.1 Comparison of the experimental and manufacturer's membrane permeability

Figure 7.2 Results of water filtration in cross-flow and dead-end mode of operation

Figure 7.3 Comparison of water flux and steady state filtration of aqueous feed solution

Figure 7.4 Graphical analysis of the aqueous solution flux over time

Figure 7.5 Graphical analysis of the aqueous solution for various feed concentrations

Figure 7.6 SEM images of membrane surface with and without fouling

Figure 7.7 Graphical plot of the linearized Hermia model applied to Run 5

Figure 7.8 Graphical analysis of the aqueous feed filtration and membrane cleaning intervals

Figure 7.9 Conceptual approach to the filtration/fouling and cleaning intervals experiments

Figure 7.10 Filtration of CUBEN effluent with sodium hydroxide backwashing intervals

Figure 7.11 Filtration of CUBEN effluent with hydrochloric acid membrane soaking 


\section{LIST OF TABLES}

Table 1.1 Membrane bioreactor installations in North America

Table 2.1 Typical residual constituents found in wastewater effluents and their impacts

Table 2.2 Property differences between solutions

Table 2.3 Relevant types of unit operations for the removal of various components

Table 2.4 Typical feed water quality

Table 2.5 Apparent dimensions of small particles, molecules and ions

Table 3.1 Basic concepts of membrane separation processes

Table 3.2 Comparison of some of the different membrane module configurations

Table 3.3 Various materials used for membrane fabrication

Table 3.4 Primary operational characteristics of membrane filtration processes

Table 3.5 Relative comparison of TMF and MBR

Table 4.1 Various commercially available ceramic membranes

Table 5.1 Comparison of concentration polarization and membrane fouling characteristics

Table 5.2 General forms of the membrane flux equation

Table 5.4 Parameters for the blocking filtration laws

Table 5.5 Typical types of fouling and the constituents in wastewater that cause fouling

Table 5.6 Factors influencing the effectiveness of ultrasound

Table 6.1 Equipment/materials of the membrane apparatus

Table 6.2 Description of the Media Process Technology ceramic membrane

Table 6.3 Composition of the effluent wastewater from CUBEN

Table 6.4 List of chemicals utilized for cleaning 
Table 6.5 Manufacturer's membrane flux values attainable

Table 6.6 Matrix of the aqueous solution trial runs

Table 6.7 Cleaning methods experimented

Table 7.1 Hermia model results of $\varphi$ to describes type of fouling 104

Table 7.2 Collected data from the experimental trial of aqueous solution feed with cleaning 105

Table 7.3 Tabulated data and flux recovery for backwashing using various chemicals

Table 7.4 Tabulated data and flux recovery of chemical solutions used for membrane soaking 


\section{LIST OF APPENDICES}

Appendix A Membrane and Ultrasound Equipment Suppliers

Appendix B General Forms of the Membrane Flux Equations and Blocking Laws

Appendix C Figures of Pore Size Range and Process Diagram -8- 


\section{NOMENCLATURE}

A Surface area of the membrane of the filtering module $\left(\mathrm{m}^{2}\right)$

$A_{M} \quad$ Membrane area $\left(\mathrm{m}^{2}\right)$

C Solute concentration at the membrane surface $(\mathrm{mg} / \mathrm{L})$

$C_{B} \quad$ Concentration in the bulk water $(\mathrm{mg} / \mathrm{L})$

$C_{F} \quad$ Concentration in the feedwater $(\mathrm{mg} / \mathrm{L})$

$C_{M} \quad$ Concentration of solute maintained on the feed side of the membrane $(\mathrm{mg} / \mathrm{L})$

$C_{P} \quad$ Concentration in the permeate $(\mathrm{mg} / \mathrm{L})$

$C_{R} \quad$ Concentration in the retentate $(\mathrm{mg} / \mathrm{L})$

$d_{p} \quad$ Particle or molecular diameter $(\mathrm{m})$

$D \quad$ Solute diffusivity $\left(\mathrm{m}^{2} / \mathrm{s}\right)$

$h \quad$ Hydraulic diameter of the flow channel (m)

$J \quad$ Permeate flux $\left(\mathrm{L} / \mathrm{m}^{2} \cdot \mathrm{s}\right)$

$j_{w} \quad$ Flux density of water through membrane $\left(\mathrm{L} / \mathrm{m}^{2} \cdot \mathrm{s}\right)$,

$k \quad$ Mass transfer coefficient $(\mathrm{m} / \mathrm{s})$

$P \quad$ Applied pressure (atm)

$P_{F} \quad$ Pressure of the feed water $(\mathrm{atm})$

$P_{R} \quad$ Pressure of the retentate water (atm)

$P_{P} \quad$ Pressure of the permeate water (atm)

$\Delta P \quad$ Pressure Difference or TMP (atm)

$Q \quad$ Flowrate $(\mathrm{L} / \mathrm{hr})$

$Q_{F} \quad$ Feed flowrate $(\mathrm{L} / \mathrm{hr})$

$Q_{P} \quad$ Flow rate of the filtered water $(\mathrm{L} / \mathrm{hr})$

$Q_{R} \quad$ Flow rate of the concentrated water $(\mathrm{L} / \mathrm{hr})$

$R \quad$ Retention (dimensionless)

$r \quad$ Recovery $(\%)$

$R_{f} \quad$ Resistance due to fouling $(1 / \mathrm{m})$

$R_{m} \quad$ Resistance of the membrane $(1 / \mathrm{m})$

$R_{t o t} \quad$ Total resistance over membrane $(1 / \mathrm{m})$

$t$ Time (s or hr) 
T temperature $\left({ }^{\circ} \mathrm{C}\right)$

$V \quad$ Filtered volume (L)

$V_{F} \quad$ Volume of water fed to membrane over filtration run (L)

$V_{B W} \quad$ Volume of water used during backwash (L)

\section{Greek symbols}

$\alpha_{c} \quad$ Specific cake resistance $(\mathrm{m} / \mathrm{g})$

$\beta \quad$ Blocking law filtration coefficient

$\varphi \quad$ Blocking law filtration exponent (unitless)

$\mu \quad$ Dynamic viscosity $\left(\mathrm{N} \cdot \mathrm{s} / \mathrm{m}^{2}, \mathrm{~Pa} \cdot \mathrm{s}\right)$

\section{Subscripts}

Ads Adsorption

$B \quad$ Bulk

$c p \quad$ Concentration polarization

$C$ Concentrate

$f \quad$ Fouling

$F \quad$ Feed

$i \quad$ Membrane unit number

irrev Irreversible

m Membrane unit

M Membrane

$P \quad$ Permeate

rev Reversible

$R \quad$ Retentate

SS Steady-state

tot Total

\section{Abbreviations}

AWWARF American Water Works Association Research Foundation CA Cellulose acetate 
CEB Chemically Enhanced Backwash/Backflush

CT Capillary tube

CUBEN Compact Upright Bioreactor for the Elimination of Nutrients

ED Electrodialysis

EDS Energy Dispersive Spectroscopy

FC Filter cartridge

FS plate and frame or flat sheet/plate

GE General Electric

HF Hollow fibre

IUPAC International Union of Pure and Applied Chemists

MBR Membrane Bioreactor

MF Microfiltration

MT Multi-tubular

MWCO Molecular Weight Cut-Off

NF Nanofiltration

NOM Natural Organic Matter

PES Polyethylsulphone

PP Polypropylene

PVDF Polyvinylidene diflouride

RO Reverse Osmosis

SEM Scanning Electron Microscope

SW Spiral-wound

TCFE Tubular Ceramic Filter Element

TMF Tertiary Membrane Filtration

TMP Transmembrane Pressure

TSS Total Suspended Solids

UF Ultrafiltration

U.S.EPA U.S. Environmental Protection Agency

VCF Volumetric Concentration Factor (dimensionless)

WEF Water Environment Federation 


\subsection{INTRODUCTION}

\subsection{Introduction to the Problem Definition}

The Department of Chemical Engineering at Ryerson University is developing expertise in the area of membrane technology. An experimental membrane facility using porous ceramic membranes has been built in the water/wastewater laboratory.

The use of membranes to successfully remove suspended and dissolved particles from a process stream for reuse of the effluents is becoming the technology of choice. As the world's fresh water supply decreases due to the demands of human needs, the development of membrane technologies is becoming vital and valuable as a way to clean polluted waters that we produce. Some benefits of membrane technologies:

$>$ Versatility in different industries

$>$ Diversity in membrane materials

$>$ Ability to separate pollutants/contaminants in wastewaters

$>$ Large support in either secondary or tertiary wastewater treatment

$>$ Simplicity in the use for separation/filtration (versus other separation processes)

$>$ Wide spread ease to be used in combination with other devices, modules or applications

$>$ Drive or need to protect the public health and environment

$>$ Applicable to both small and large scale applications

$>$ Short hydraulic retention time compared to conventional filters (e.g. gravity sand filters)

There are many applications for membrane treatment processes and numerous membrane arrangement configurations, alone or in combination with other devices. The diverse fields of membrane applications within different industries with some examples are as follows (also see Table 1.1):

Dairy industry (fluid milk and fermented products, cheese manufacture, milk microfiltration, cheese whey ultrafiltration, microfiltration of whey)

$>$ Food and Beverage Industry (protein and gelatin processing, clarification of juices and vegetable oils, alcoholic beverages)

$>$ Biotechnology applications (separation and harvesting of microbial cells, enzyme recovery)

$>$ Textile industry (latex emulsions)

$>$ Tanning and leather industries 
$>$ Pulp and paper industry

$>$ Water treatment (process water and drinking water)

$>$ Wastewaters (oily wastewaters, stillage from bioethanol plants, caustic and acid recovery, domestic and laundry wastewater)

Table 1.1 Membrane bioreactor installations for industrial wastewater treatment plants in North America (adapted from: Yang et al., 2006)

\begin{tabular}{|l|c|c|}
\hline \multicolumn{1}{|c|}{ Wastewater resource } & $\begin{array}{c}\text { Number of plants (of a } \\
\text { total of } 39 \text { surveyed) }\end{array}$ & $\begin{array}{c}\text { Capacity range } \\
\text { ( } \mathbf{m}^{3} / \text { day) }\end{array}$ \\
\hline Food/beverage processing & 10 & 18 to $>$ than 170 \\
\hline Chemical plant & 7 & 19 to 500 \\
\hline Automotive plant & 5 & 8 to $>$ than 114 \\
\hline Fiberglass manufacturing & 2 & 80 to 871 \\
\hline Metal processing plant & 1 & 227 \\
\hline Diary plant & 1 & 908 \\
\hline Landfill leachate & 1 & 114 \\
\hline Computer firms & 1 & 1 \\
\hline Pharmaceutical plant & 1 & 72 \\
\hline Other & 10 & 3 to $>$ than 19 \\
\hline
\end{tabular}

\section{History of Ceramic Membranes}

Membranes and membrane processes were not considered viable until the mid-1970 when they were commercialized. The field of membrane separation technology is originally dominated by polymer membranes; however the growth of ceramic membranes has been very fast in the last twenty years. The rapid development and innovations of ceramic membranes are depicted by the timeline of establishments in Figure 1.1. Some of the early milestones started around the 1900's including oxygen ions diffused though ceramic membranes that separated oxygen from a toxic atmosphere. In the mid-1920 the cities of Phoenix and Los Angeles first installed ceramic plate/disc diffusers for their aeration systems in the wastewater treatment. Later in the mid-1930 the Cobham Engineering and Technology Company Limited produced primarily filtration and separation technologies of micro filtration/coalescence using ceramic membranes for emulsified water and oil treatment. In the late 1950 the Foshan Ceramics Research Institute \& Jin Gang Group enterprise was founded focusing in technology research, technical service, sales and marketing, manufacturing, economical trading and journal publishing of a variety of ceramic products together with ceramic membrane filters, with current annual sales totaling over US $\$ 40 \mathrm{M}$. 


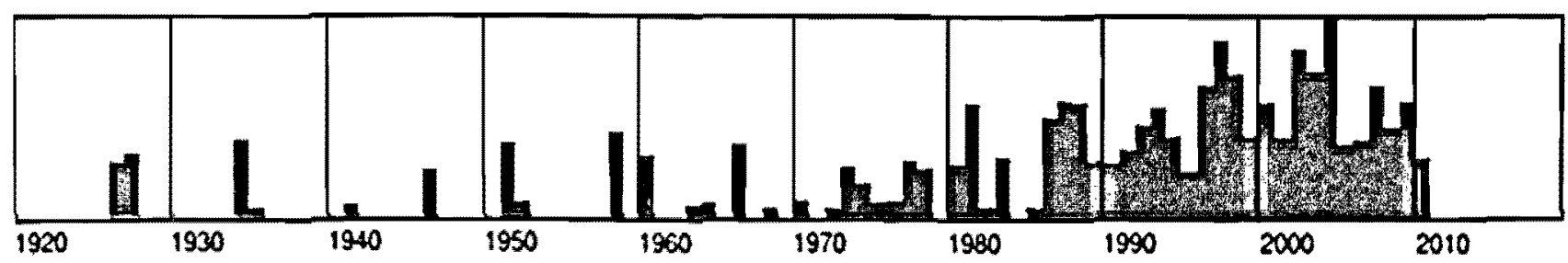

Figure 1.1 Timeline of establishments for ceramic membranes.

(source:http:/www.google.ca/search?q=ceramictmembranethistory\&h)=en\&rlz=1T4SUNC_enCA362CA362\&prm

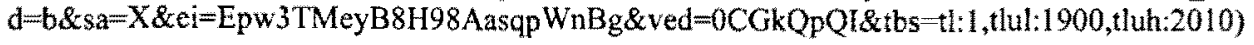

Further innovations of ceramic membranes in the 1980s and 1990s include applications such as: $\mathrm{pH}$ reference electrodes (patent MacDonald, 1983), technical manuals and case studies of oxygen transfer in fine bubble diffusers for municipal wastewater treatment plants (U.S.EPA, 1989), development of ceramic ultrafilters by Noritake Co Ltd produced by sol-gel coating (1993), gas permeable membrane for biological reactions (patent Stephanopoulos et al., 1990) and experimental studies of a ceramic membrane reactor for hydrogen purification (patent Edlund, 1996). Other developments into the design and performance of more durable ceramic membranes and new business ventures have been established. In the present century advanced innovations into specific contaminant and pollutant removal as targets are investigated

Presently, membrane processes are used for matters such as seawater desalination, wastewater purification, ultra pure water, separation of molecular mixtures in the food and drug industry, artificial organs as well as therapeutic functions. Hence the most popular membrane industry markets currently consist of water and wastewater treatment, food and beverage processing, pharmaceutical and medical uses, chemical processing and industrial gas processing. It has been reported that there are 39 leading competitors for these markets, some of the big names include: General Electric, Pall, Millipore, Hydranautics, Dow Chemical, Siemens, Toray, 3M and Koch Membrane Systems. The forecast for worldwide demands of membranes is projected to grow at $8.6 \%$ annually to US $\$ 15.1$ billion by 2012 (Freedonia, 2008). For a list of some world-wide membrane suppliers/contacts, see Appendix A.

\section{Market}

In 2003, the global giant General Electric (GE) purchased Osmonics (which makes membranes for use in water treatment) thus launching GE Water Technologies, now worth US\$1.4 billion. Later that same year they bought Ionics (a U.S.-based desalination plant) for US $\$ 1.1$ billion, as well as 
Zenon Environmental Inc. (which make ultrafiltration membranes) (Barlow, 2007). The consolidation of industry giants has been driven by the trend to improve product and service capabilities. Due to elevated capital and technical requirements, brand reputation and established patent protection by existing industry participants, the entrance barrier to the membrane market is extremely high (Chu, 2009).

In 1998, membranes and module sales alone were estimated at more than US $\$ 4.4$ billion worldwide (Nunes, 2006). This was a combined evaluation of various membrane process applications: electrodialysis, gas separation, hemodialysis, microfiltration, ultrafiltration and reverse osmosis, with majority of it owing to hemodialysis/hemofiltration. Although equipment and total membrane system costs were not considered in the estimate, it was approximated that the value would double if taken into account.

In contrast, throughout 2004, the world gross domestic product (GDP) growth had put forward rates of $2.4 \%$ in $2001,3.0 \%$ in $2002,3.2 \%$ in 2003 and $4.1 \%$ in 2004 . It was then projected the profile would settle to between 3.0 and $3.5 \%$ for the next five years due to a settled forecast of the U.S. market (average of 1.9\%) during those years. (Sutherland, 2004). However, in a recent report, it was given that the current global GDP is on average $4.9 \%$ and a U.S. GDP of $2.2 \%$. (Water and Wastewater News, 2009). It is acknowledged that the membrane industry has sales of several US billion dollars per year and is still progressively growing by rates more than $10 \%$ per year (Strathmann, 2006).

In another recent study published in 2008 , the forecast for worldwide demands of membranes is projected to grow at $8.6 \%$ annually (to US $\$ 15.1$ billion) in 2012 (Freedonia, 2008). The research study further suggests that, due to ongoing interest in higher purity process fluids and stricter water/wastewater quality policies, the membrane materials demand, in merely the U.S. alone, will rise $8.2 \%$ annually through till 2012 . The current status of the US membrane industry is set at US $\$ 2.9$ billion. North America has the largest regional membrane market and encompassed onethird of the global membrane sales in 2007 (World Membrane Markets, 2009). The United States holds about $40 \%$ of the market, $29 \%$ is shared by Europe and the Middle East, while Asia and South America are quickly growing (Nunes, 2006). 
The market for membranes and their applications in water/wastewater treatment is influenced by many factors. Some of these factors include: new or tighter bylaws; water scarcity; introducing improvements of technologies, particularly in recycling; decrease in investment costs; and increase confidence in and acceptance of Membrane Bioreactor (MBR) technology. See Figure 1.2 which shows both positive (drivers) and negative (restraints) triggers of the membrane and membrane technology market.

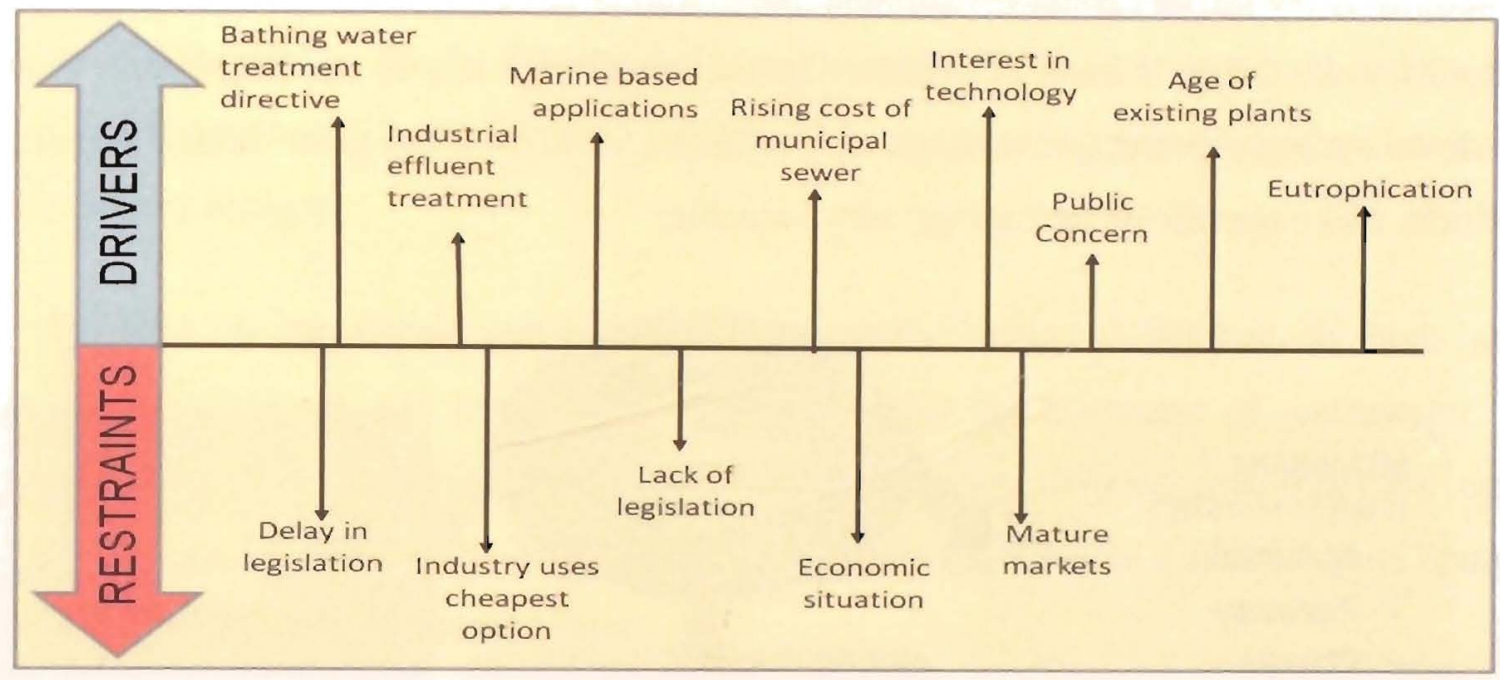

Figure 1.2 Factors influencing the market (source: Judd, 2006).

Membrane filtration processes working under an applied pressure (i.e., microfiltration, ultrafiltration, nanofiltration and reverse osmosis) have been shown to successfully fulfil most of the problems related to other conventional separation technologies. For example, in drinking-water treatment, slow sand filtration produces low filtration rates or in fast granular filtration, which usually requires chemical coagulation pretreatment, produces an effluent quality that deteriorates over a period of operation time. Although in the past, the practice of tertiary sand or media filtration processes for wastewater treatment, have been shown to be effective, the focus here is to exploit membrane filtration for solid-liquid separation and moreover to treat contaminated waters/wastewaters.

Compared to many of the existing separation applications, membrane processes are considered to be more often energy efficient, simple to operate and produces a higher quality yield. With the selection of proper designs, membrane technology for water and wastewater treatments, have been capable in achieving excellent quality standards. In surface water purification and wastewater 
treatment, membrane processes like microfiltration and ultrafiltration are competing with flocculation, sand bed filtration, carbon adsorption, ion-exchange and even biological treatment. Membrane processes can be more costly than the applications just mentioned, but it is found that the combination of conventional processes with a membrane process can result in reliable and costeffective treatment. The comparison of membrane processes to conventional separation processes (e.g. distillation or sand filtration), is reported to be more time and energy saving, and produces reductions in the initial capital investments (Bernardo et al., 2004; Porter, 1990; Singh et al., 2006; Maroulis et al., 2003; Ibarz et al., 2003). The ability for high efficiency, simple operation, easy up and down scaling, operating at ambient temperatures, while avoiding great change or degradation of products, make membrane technology very valuable.

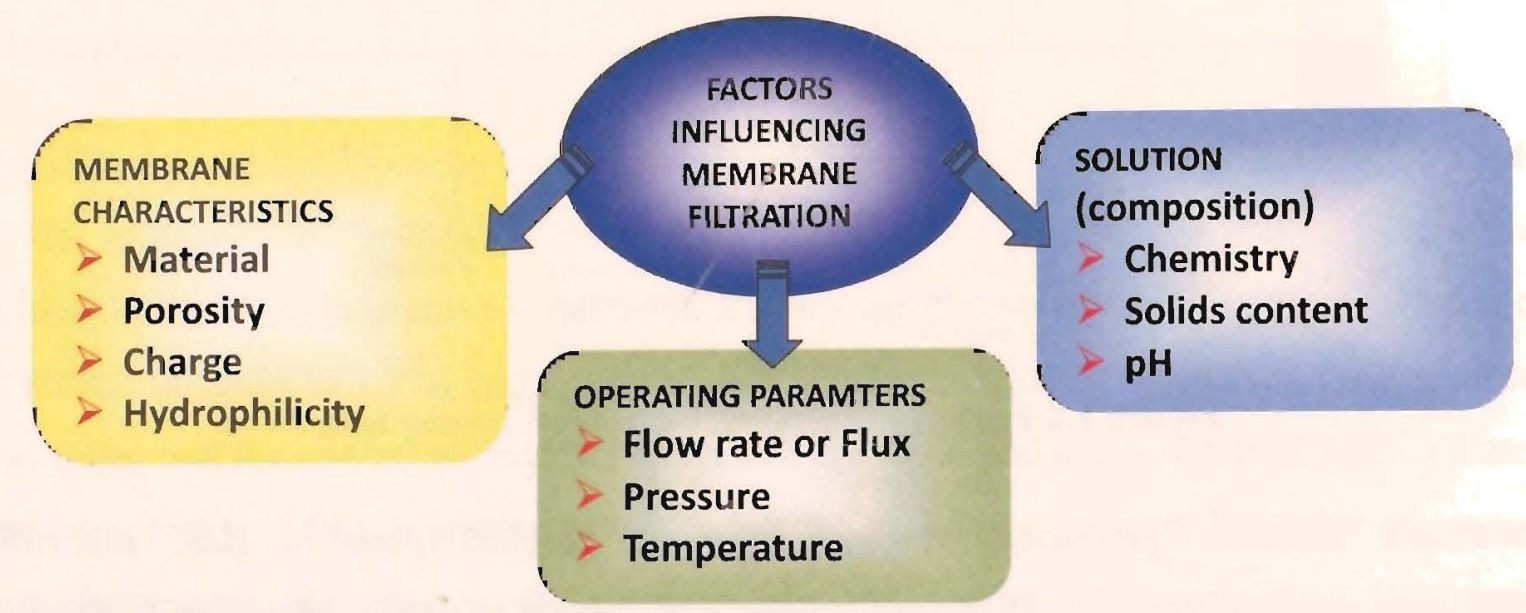

Figure 1.3 Factors affectirig membrane filtration.

Generally, the choice in selecting the right membrane process will depend on various matters including, effluent quality, local conditions, economic costs, required capacity and the goal of the treatment application. Further, concerns in the design of a membrane filtration process unit include characteristics of the membrane, characteristics of the solution to be treated, as well as operating conditions based on suitable parameters, see Figure 1.3. These matters must be carefully planned and managed in order to effectively produce the desired outcome.

Most commonly polymer membranes such as cellulose acetate (CA), polyvinylidene diflouride (PVDF), polyethylsulphone (PES) or polypropylene (PP) are used and manufactured as the material for membranes, especially in the water/wastewater industries. In some other industries, materials 
such as ceramics are used. Ceramic membranes have gained attraction due to advantages such as stability towards $\mathrm{pH}$ resistance, chemical attack, abrasion, high pressure and high temperature, when compared to polymer membranes. There are a wide variety of materials for membrane use in many industries. The membrane processes vary and can be categorized by the pore size or the retention of substances in the fluid to be treated. In water and wastewater treatment, membrane filtration processes by pore size (largest to smallest pore size) are: microfiltration, ultrafiltration, nanofiltration and reverse osmosis. Further details into membranes and types of processes are illustrated in Chapter 1. While investigations are made into developing membranes of better chemical and thermal stability and overall performance, progress is being made into the sensitivity of membranes to foulants.

Rapid advances in membrane technology are currently being undertaken in both research (academic), development and commercial applications for the treatment of wastewater. Most bench-scale and pilot-scale studies of the membrane technology coupled with other processes for treatment of domestic wastewater have occurred in Australia, Canada, China, Japan, France, the Netherlands, Poland, and the United States.

Despite the potential of membrane applications in water and wastewater treatment, certain limitations challenge their ease of large-scale applications and continued operation. One of the major limitations arises from membrane fouling. The need to remove contaminants from effluents (such as suspended solids or floatable solids and erosive or chemical substances) is necessary, but these contaminants cause membrane fouling and deterioration. The occurrence of membrane fouling is a concern in the operation of membrane filtration, which holds at the moment as the major problem with the application. Fouling in membrane processes is the process resulting in loss of performance of a membrane due to the deposition of suspended or dissolved substances on its external surfaces, at its pore openings, or within its pores (definition from International Union of Pure and Applied Chemists, IUPAC). Therefore, the following section describes the objectives of this thesis which includes some investigation and evaluation of cleaning of fouled membranes. 


\subsection{Objectives of this Thesis}

\section{Research Objectives}

The main objective of this thesis is to develop the area of ceramic membrane bioreactors in the Department of Chemical Engineering. The following itemizes the intentions:

1. Design and build a laboratory scale ceramic membrane filtration unit with connection to be used with CUBEN (Compact Upright Bioreactor for the Elimination of Nutrients) which is a multistage bioreactor)

2. Implement start-up operations, such as to calibrate the membrane filtration facility and test various flow rates and pressures using distilled water

3. Evaluate the unit by performing membrane filtration experiments using an aqueous precipitated feed solution at various feed flow rates and concentrations

4. Determine a cleaning method or solution for the membrane fouling

5. Evaluate the membrane filtration trials of a synthetic wastewater feed (effluent from the above bioreactor) incorporated with a cleaning regime for the ceramic membranes

This thesis should improve our understanding of the operations and maintenance of membrane filtration and/or membrane bioreactors applied to water and wastewater treatment. Moreover, a better understanding of the membrane filtration unit built in the laboratory is realized. With the construction of a simple membrane unit, separation and treatment of solid waste from tertiary wastewaters for reuse is achievable.

The study starts with a review of constituents in the water/wastewater environment. This is followed by a review of technology concepts, membrane processes, such as membrane material and structure, fouling aspects and cleaning techniques of fouled membranes. The experimental section includes the procedure and set-up of the equipment, wastewater characteristics, operating procedures and analytical methods. Start-up and calibration of the ceramic membrane unit is carried out to verify operation settings of the unit. Testing of the unit when filtered with an aqueous solution containing suspended solids is executed. The aqueous solution which contains particulate matter is prepared for use as the experimental feed solution to assess the extent of fouling. Removal of solids by 
membrane separation is experimentally examined followed by a method to clean/control fouled membranes. The design of the apparatus and examination to optimize for effective filtration and/or cleaning conditions, such as flow rate, pressure and solute concentration, are implemented. A final investigation using wastewater from a bioreactor is filtered through the unit together with membrane cleaning. In order to determine the successful achievement and enhanced performance of the membrane unit, analytical monitoring is carried out in terms of $\mathrm{pH}$, turbidity and suspended solids concentrations. Finally, the data and results are discussed. 


\subsection{CONSTITUENTS AND TREATMENT TECHNOLOGIES}

Contaminants in water include a wide spectrum of chemicals and pathogens. Analysis of contaminants in water/wastewater can be performed by physical, chemical and biological methods. Common physical tests include temperature, solids concentration (e.g. total suspended solids) and turbidity. Examination methods using analytical chemistry principles include $\mathrm{pH}$, biochemical oxygen demand, chemical oxygen demand, nutrients, metals, oil and grease, etc., for both organic and inorganic compounds. Biological and microbial testing can include BOD, bacterial water and pathogen analysis.

In the journey to preserve existing global water resources, much focus in regards to membranes has been shifted towards water recovery, reuse and recycling. Capabilities of micro- and ultra-filtration as advanced treatment for reuse and for effluent polishing have already been early established (Roorda J., 2004). Effluent water quality is determined by focusing on reducing specific contaminants, nutrient removal and disinfection before discharge of the effluent to surface waters.

Advanced wastewater treatment is the application to remove constituents. Constituents may be grouped into four categories

(1) the residual organic and inorganic colloidal and suspended solids,

(2) dissolved organic constituents,

(3) dissolved inorganic constituents and

(4) biological constituents.

Table 2.1 lists typical residual constituents found in wastewater treatment effluents and their effects. Suspended constituents in a solution are a mixture of one or more components which have a particle size greater than $10^{-5} \mathrm{~cm}(0.1$ micron), usually visible to the naked eye. Colloidal solids in solution have particle sizes in the range between $10^{-7}$ to $10^{-5} \mathrm{~cm}(0.001$ to 0.1 micron). Examples include milk, blood, ink, starch solution, etc. Dissolved matter or solutes are not visible to the naked eye or under a powerful microscope. 
Table 2.1 Typical residual constituents found in wastewater effluents and their impacts (Metcalf \& Eddy, 2003).

\begin{tabular}{|c|c|}
\hline Residual constituent & Effect \\
\hline \multicolumn{2}{|c|}{ Inorganic and organic colloidal and suspended solids } \\
\hline \multirow[t]{2}{*}{ Suspended solids } & - may cause sludge deposits or interfere with receiving water clarity \\
\hline & - can impact disinfection by shielding organisms \\
\hline Colloidal solids & - may affect effluent turbidity \\
\hline Organic matter (particulate) & - may shield bacteria during disinfection, may deplete oxygen resources \\
\hline \multicolumn{2}{|l|}{ Dissolved organic matter } \\
\hline Total organic carbon & - may deplete oxygen resources \\
\hline Refractory organics & - toxic to humans; carcinogenic \\
\hline Volatile organic compounds & - toxic to humans; carcinogenic; form photochemical oxidants \\
\hline Pharmaceutical compounds & - impact aquatic species (e.g. endocrine disruption, sex reversal) \\
\hline Surfactants & - causes foaming and may interfere with coagulation \\
\hline \multicolumn{2}{|l|}{ Dissolved inorganic matter } \\
\hline \multirow[t]{4}{*}{ Ammonia } & - increases chlorine demand for disinfection \\
\hline & - can be converted to nitrates and can deplete oxygen resources \\
\hline & - with phosphorous, may lead to undesirable aquatic weed growth \\
\hline & - unionised form toxic to fish \\
\hline Nitrate & - stimulates algal and aquatic growth \\
\hline \multirow[t]{3}{*}{ Phosphorus } & - stimulates algal and aquatic growth \\
\hline & - interferes with coagulation \\
\hline & - interferes with lime-soda softening \\
\hline Calcium and magnesium & - increase hardness and total dissolved solids \\
\hline Total dissolved solids & - interfere with agricultural and industrial processes \\
\hline \multicolumn{2}{|l|}{ Biological } \\
\hline Bacteria & - may cause diseases \\
\hline Protozoan cysts and oocysts & - may cause diseases \\
\hline Viruses & - may cause diseases \\
\hline
\end{tabular}


A true solution is a homogenous solution where the differentiation between solute and solvent molecules is not distinguishable and solute particles have diameters less than $10^{-7} \mathrm{~cm}$. Table 2.2 shows the differences between a true solution, a colloidal solution and a suspension.

Table 2.2 Differences between true solutions, suspensions and colloids

\begin{tabular}{|l|c|c|c|}
\hline Property & True solutions & Colloidal solutions & Suspensions \\
\hline Particle size & Less than $10^{-7} \mathrm{~cm}$ & Between $10^{-5}$ and $10^{-7} \mathrm{~cm}$ & Greater than $10^{-5} \mathrm{~cm}$ \\
\hline $\begin{array}{l}\text { Visibility of } \\
\text { particles }\end{array}$ & $\begin{array}{c}\text { Invisible to naked eye } \\
\text { not visible under } \\
\text { powerful microscope }\end{array}$ & $\begin{array}{c}\text { Invisible to naked eye. Visible } \\
\text { under powerful microscope }\end{array}$ & Easily visible \\
\hline $\begin{array}{l}\text { Sedimentation of } \\
\text { particles }\end{array}$ & Do not settle down & $\begin{array}{c}\text { Settle down under high } \\
\text { centrifugation }\end{array}$ & $\begin{array}{c}\text { Settle down due to } \\
\text { gravity }\end{array}$ \\
\hline $\begin{array}{l}\text { Filtration through } \\
\text { filter paper }\end{array}$ & No residue is formed & No residue is formed & Residue is formed \\
\hline
\end{tabular}

Applicable treatment processes to remove constituents is summarized in Table 2.3. These processes or treatment technologies can be operated alone or in combination to achieve the water quality. Pollution by refractive compounds like endocrine disruptors into surface waters can be a serious problem in many parts of the world and arises from a wide variety of sources. For example, phosphorous, a plant nutrient, exists in the environment as phosphates with a low solubility and rapid transformation to insoluble forms, making the element a growth-limiting nutrient. Excess quantities of phosphorous can lead to extensive growth of phytoplankton, macroalgae and higher plants.

In water pollution, pathogens are organisms that cause illness or disease to humans. Options to eliminate pathogenic microbes include pretreatment, coagulation/flocculation/sedimentation, and filtration processes. Removal of particulate matters by micro- and ultra-filtration reduces the concentration of high-molecular-mass colorants, suspended solids and turbidity of feed water. The process is ideal for removal of small particles from drinking water. It has been reported that turbidities as low as 0.1 to 0.4 NTU are attainable from levels of up to $100 \mathrm{NTU}$ and higher. The flux may vary depending on the type of membrane used and the applied pressure which is in the range of 1 to $5 \mathrm{~atm}$. 
Table 2.3 Relevant types of unit operations for the removal of various components (Metcalf \& Eddy, 2003).

\begin{tabular}{|c|c|c|c|c|c|c|}
\hline \multirow[b]{2}{*}{ Residual constituent } & \multicolumn{6}{|c|}{ Unit operation or process (1) } \\
\hline & $\begin{array}{l}\text { Multi-media } \\
\text { filtration }\end{array}$ & $\begin{array}{l}\text { Surface } \\
\text { filtration }\end{array}$ & $\begin{array}{c}\text { Micro-and } \\
\text { ultrafiltration }\end{array}$ & $\begin{array}{l}\text { Reverse } \\
\text { osmosis }\end{array}$ & Electrodialysis & Adsorption \\
\hline \multicolumn{7}{|c|}{ Inorganic and organic colloidal and suspended solids } \\
\hline Suspended solids & $x$ & $x$ & $x$ & $x$ & $x$ & $x$ \\
\hline Colloidal solids & $x$ & $x$ & $x$ & $x$ & $x$ & $x$ \\
\hline Organic matter (particulate) & & & & $x$ & $x$ & \\
\hline \multicolumn{7}{|l|}{ Dissolved organic matter } \\
\hline Total organic carbon & & & & $x$ & $\mathrm{x}$ & $x$ \\
\hline Refractory organics & & & & $x$ & $x$ & $x$ \\
\hline Volatile organic compounds & & & & $x$ & $x$ & $x$ \\
\hline \multicolumn{7}{|l|}{ Dissolved inorganic matter } \\
\hline Ammonia & & & & $x$ & $x$ & \\
\hline Nitrate & & & & $x$ & $x$ & \\
\hline Phosphorus & $x$ & & & $x$ & $x$ & \\
\hline Total dissolved solids & & & & $x$ & $x$ & \\
\hline \multicolumn{7}{|l|}{ Biological } \\
\hline Bacteria & & & $x$ & $\bar{x}$ & $x$ & \\
\hline Protozoan cyst and oocyst & $x$ & & $x$ & $x$ & $x$ & $x$ \\
\hline Viruses & & & & $x$ & $x$ & \\
\hline & \multicolumn{6}{|c|}{ Unit operation or process (2) } \\
\hline Residual constituent & Air stripping & $\begin{array}{c}\text { lon } \\
\text { exchange }\end{array}$ & $\begin{array}{l}\text { Advanced } \\
\text { oxidation } \\
\text { processes }\end{array}$ & Distillation & $\begin{array}{l}\text { Chemical } \\
\text { precipitation }\end{array}$ & $\begin{array}{l}\text { Chemical } \\
\text { oxidation }\end{array}$ \\
\hline \multicolumn{7}{|c|}{ Inorganic and organic colloidal and suspended solids } \\
\hline Suspended solids & & $x$ & & $x$ & $x$ & \\
\hline Colloidal solids & & $x$ & & $x$ & $x$ & \\
\hline Organic matter (particulate) & & & & $x$ & & $x$ \\
\hline \multicolumn{7}{|l|}{ Dissolved organic matter } \\
\hline Total organic carbon & & $x$ & $\mathrm{x}$ & $\bar{x}$ & $\mathrm{x}$ & $\bar{x}$ \\
\hline Refractory organics & & & $x$ & $x$ & & \\
\hline Volatile organic compounds & $x$ & & $x$ & $x$ & & \\
\hline \multicolumn{7}{|l|}{ Dissolved inorganic matter } \\
\hline Ammonia & $x$ & $x$ & & $x$ & & \\
\hline Nitrate & & $x$ & & $x$ & & \\
\hline Phosphorus & & & & $x$ & $x$ & \\
\hline Total dissolved solids & & $x$ & & $x$ & & \\
\hline \multicolumn{7}{|l|}{ Biological } \\
\hline Bacteria & & & & $x$ & & \\
\hline Protozoan cyst and oocyst & & $x$ & & $x$ & $x$ & \\
\hline Viruses & & & & $x$ & & \\
\hline
\end{tabular}


Characteristics of the wastewater are important to ensure compatibility of the membrane process selected to treat the wastewater. The characteristics of wastewater define the ingredients that makeup wastewater and the quality of the water. Different types of wastewater arise from domestic or industrially specific, or can be a combination of both. Table 2.4 gives an example of a typical feed water quality to a membrane facility.

Table 2.4 Typical water quality after secondary treatment (addated from: WEF, 2006)

\begin{tabular}{|l|l|l|}
\hline Parameter & Units & \multicolumn{1}{l|}{$\begin{array}{l}\text { Secondary } \\
\text { Effluent }\end{array}$} \\
\hline Biochemical oxygen demand & $\mathrm{mg} / \mathrm{L}$ & $5-30$ \\
\hline Total KJeldahl nitrogen & $\mathrm{mg} / \mathrm{L}$ as $\mathrm{N}$ & $10-20$ \\
\hline Total phosphorus & $\mathrm{mg} / \mathrm{L}$ as $\mathrm{P}$ & $1-8$ \\
\hline Total suspended solids & $\mathrm{mg} / \mathrm{L}$ & $5-25$ \\
\hline Turbidity & $\mathrm{NTU}$ & $2-500$ \\
\hline $\mathrm{pH}$ & $\mathrm{S} . \mathrm{H}$ & $6-9$ \\
\hline Temperature & ${ }^{\circ} \mathrm{C}$ & $8-30$ \\
\hline Total coliforms & $\mathrm{No} / 100 \mathrm{~mL}$ & $50000-2000000$ \\
\hline Fecal coliforms & No. $/ 100 \mathrm{~mL}$ & $10000-1600000$ \\
\hline Viruses & *PFU $/ 100 \mathrm{~mL}$ & $0.05-1000$ \\
\hline
\end{tabular}

Table 2.5 Apparent dimensions of small particles, molecules and ions (adapted from: WEF, 2006)

\begin{tabular}{|l|c|c|}
\hline Species & $\begin{array}{c}\text { Range of } \\
\text { Dimensions (nm) }\end{array}$ & $\begin{array}{c}\text { Molecular } \\
\text { Weight (Da) }\end{array}$ \\
\hline Secondary Effluent TSS & $1000-150000$ & \\
\hline Giardia lamblia cysts & $8000-12000$ & \\
\hline Cyclospora cayetanensis cysts & $8000-10000$ & \\
\hline Cryptosporidium parvum cysts & $4000-6000$ & \\
\hline Yeasts and fungi & $1000-10000$ & \\
\hline Bacteria & $300-10000$ & \\
\hline Escherichia coli & $1100-500$ & \\
\hline Colloidal solids & $100-1000$ & \\
\hline Viruses & $30-300$ & \\
\hline Hepatitis A virus & 27 & \\
\hline Proteins/polysaccharides & $2-10$ & $10^{4}-10^{6}$ \\
\hline Enzymes & $2-5$ & $10^{4}-10^{5}$ \\
\hline Common antibiotics & $0.6-1.2$ & $300-1000$ \\
\hline Organic molecules & $0.3-0.8$ & $30-500$ \\
\hline Inorganic molecules & $0.2-0.4$ & $10-100$ \\
\hline Water & 0.2 & 18 \\
\hline
\end{tabular}


For membrane filtration the constituents that are of concern are suspended solids or floatable solids that could cause fouling, erosive substances that affect wear of the membrane and chemical constituents that cause deterioration of the membrane. In addition, there are significant groups of microorganisms which are of concern (e.g., filamentous bacteria, protozoa and rotifers). Bacteria are a major component that constitutes flocculation. Although they are responsible for the oxidation of organic matter, as well as nutrient transformation and producing polysaccharides or other polymeric materials that aid in flocculation of microbial biomass, they can attach and grow on the surfaces of membranes altering the chemistry of the membrane. Table 2.5 further lists typical constituents of wastewater that causes membrane fouling and deterioration. Sludge flocs in wastewater, contain mostly bacterial cells and other microorganisms, and inorganic and organic particles, with floc sizes ranging from less than $1 \mu \mathrm{m}$ to up to $1000 \mu \mathrm{m}$ (Bitton, 2005). 


\subsection{MEMBRANE FILTRATION AND TECHNOLOGY}

\subsection{Membranes}

A membrane is a permeable or semi-permeable phase in the form of a thin film. The main role of the membrane is to control the exchange of materials between two adjacent fluid phases by: acting as a barrier to sieve different species, and controlling their relative rate of transport that is a result of a driving force.

Typical objectives of the membrane process include:

$>$ Removal of total suspended solids and microorganisms as a pretreatment process for reverse osmosis;

$>$ Removal of inorganic cations and anions for water reuse applications;

$>$ Removal of specific species of organic compounds for industrial water quality management issues; and

$>$ Production of product water that is relatively free of microorganisms for industrial reuse applications;

$>$ Other objectives.

\subsubsection{Classification of Membrane Processes}

In general, membranes may be classified by pore size or molecular weight cut-off (MWCO), and the applied driving force. The removal mechanisms of pollutants are different for the various classes of membrane processes, as shown in Table 3.1. Of the membrane processes available, those that are applicable to water treatment are generally categorized into two main technologies: (1) those that retain primarily particles, UF and MF, and (2) those that retain primarily molecules and ions, NF and RO. Microfiltration (MF) and ultrafiltration (UF) operations separate impurities such as suspended solids and particles by size exclusion (sieving). Nanofiltration (NF) and reverse osmosis (RO) remove contaminants by diffusion and charge exclusion, as well as sieving. 
In water and wastewater treatment, commercial membrane applications are mainly limited to pressure driven forces of the range 0.5 bar up to $100 \mathrm{bar}$, and electrodialysis (ED) which extract problem ions such as nitrate and those ions associated with hardness or salinity (Judd S., 2006). For a wastewater treatment process, the appropriate type of membrane must be selected depending on the specific contaminants of concern, to achieve the desired effluent quality.

\subsubsection{Membrane Structure}

The performance of a membrane is strongly influenced by the physical and chemical nature of the material. Membranes may be solid or liquid, and can often be symmetric or asymmetric in structure, (seen in Figure3.1). Asymmetric membranes compared to symmetric membranes are most fouling resistant with capabilities of a higher filtration rate. Asymmetric membranes act as surface filters which reject particles at the surface. Conventional symmetric structures act as depth filters and retain particles within their internal structure, where these trapped particles plug the membrane and the flux declines during use (Porter, M.C., 1990). For membranes of asymmetric structures, the outer-skin of a membrane is the side of the surface that would be in contact with the fluid to be treated or would interact with components of the feed fluid. That is, the skin represents the actual selective barrier of the membrane. The inner-skin, approximately 100 to $200 \mu \mathrm{m}$ thick, with large pores is considered to be a support structure for the thin outer layer/skin where the thickness generally ranges from 0.1 to $1 \mu \mathrm{m}$. Outer and inner layered arrangements of membrane and support depend on whether the flow is inside-out or outside-in. From Figure 3.2, the flow patterns of the feed for some of the different modules are shown, indicated by the arrows.

Membrane morphology, pore size and orientation and porosity, are vital in the separation properties of membranes and inorganic membranes. Surface and structural features are revealed by several visibly comprehensible techniques including various microscopy methods. These tools provide optimization of materials and processing parameters during membrane preparation.

Hydrophobic membranes are susceptible to fouling by hydrophobic matter, and therefore may undergo modification of the membrane material surface to produce a hydrophilic surface if necessary (Judd S., 2006). Hydrophobicity reflects the interfacial tension between water and membrane materials. Basically, hydrophobic materials repel water and where constituents of soluble, 
non-polar or hydrophobic tend to accumulate at the solid-liquid interface (i.e., the membrane surface and fluid contact interface) to minimize the interfacial tension between the water and membrane. The method to determine hydrophobicity of membrane material is quantified by the contact angle. Typically, contact angle of membrane materials range from $40^{\circ}$ to $110^{\circ}$, where the higher the contact angle of the membrane the more susceptible to fouling is the material. For example a polymer material like polypropylene (PP) has a contact angle of about $110^{\circ}$ which identifies a hydrophobic material. Cellulose acetate (CA) is hydrophilic with a contact angle of about $40^{\circ}$ to $50^{\circ}$ which helps reduce fouling effects and maintain high flux values.

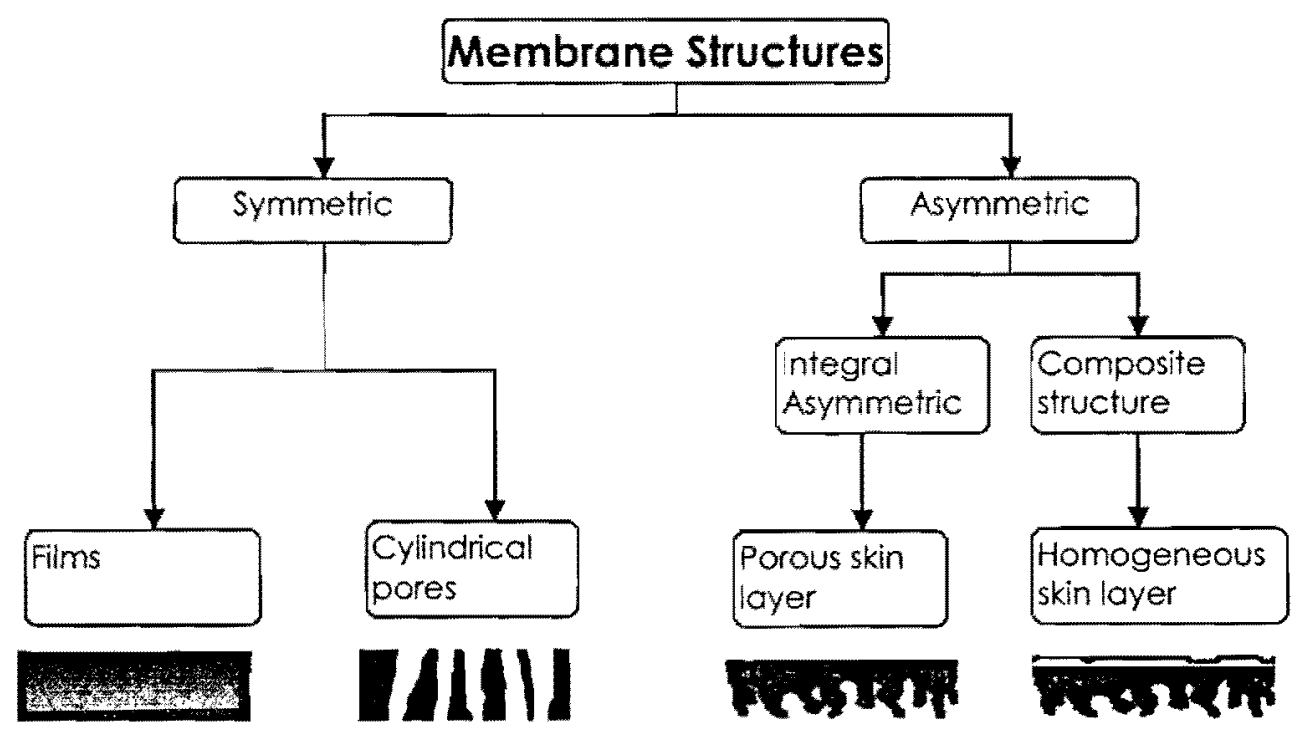

Figure 3.1 A diagram illustrating various membrane structures (adapted from: Strathmann et al., 2006). 
Table 3.1 Basic concepts of membrane separation processes, their operating principles and their applications to liquids (adapted from: Costa et al., 1991; Mulder, 1996; Strathmann et al., 2006)

\begin{tabular}{|c|c|c|c|c|c|c|c|c|}
\hline Process & $\begin{array}{l}\text { Membrane } \\
\text { Description } \\
\text { and pore size }\end{array}$ & $\begin{array}{l}\text { Applied } \\
\text { Driving } \\
\text { Force }\end{array}$ & $\begin{array}{l}\text { Mechanism } \\
\text { or Mode of } \\
\text { Separation }\end{array}$ & $\begin{array}{c}\text { Phase } \\
1 \text { (feed) }\end{array}$ & $\begin{array}{c}\text { Phase } 2 \\
\text { (permeate) }\end{array}$ & $\begin{array}{l}\text { Species } \\
\text { Passed } \\
\end{array}$ & $\begin{array}{l}\text { Species } \\
\text { Retained }\end{array}$ & $\begin{array}{l}\text { Examples of } \\
\text { Applications }\end{array}$ \\
\hline $\begin{array}{l}\text { Microfiltration } \\
\text { (MF) }\end{array}$ & $\begin{array}{c}\text { Symmetric, } \\
\text { macroporous } \\
\text { Pore radius } \\
0.1-10 \mu \mathrm{m}\end{array}$ & $\begin{array}{c}\text { Hydrostatic } \\
\text { pressure } \\
0.05-0.2 \\
\text { MPa }(0.5-2 \\
\text { bar) }\end{array}$ & $\begin{array}{c}\text { Size } \\
\text { exclusion, } \\
\text { convection }\end{array}$ & Liquid & Liquid & $\begin{array}{l}\text { solvent } \\
\text { (water) and } \\
\text { dissolved } \\
\text { solutes }\end{array}$ & $\begin{array}{l}\text { suspended } \\
\text { solids, fine } \\
\text { particulars, } \\
\text { some } \\
\text { colloids }\end{array}$ & $\begin{array}{c}\text { sterilization } \\
\text { Water } \\
\text { purification, }\end{array}$ \\
\hline $\begin{array}{l}\text { Uitrafiltration } \\
\text { (UF) }\end{array}$ & $\begin{array}{c}\text { Asymmetric, } \\
\text { Macroporous } \\
\text { Pore radius } \\
2-5 \mathrm{~nm}\end{array}$ & $\begin{array}{c}\text { Hydrostatic } \\
\text { pressure } \\
0.1-0.5 \mathrm{MPa} \\
(1-5 \mathrm{bar})\end{array}$ & $\begin{array}{l}\text { Size } \\
\text { exclusion, } \\
\text { convection }\end{array}$ & Liquid & Liquid & $\begin{array}{c}\text { solvent } \\
\text { (water) and } \\
\text { low } \\
\text { molecular } \\
\text { weight } \\
\text { (MW) } \\
\text { solutes } \\
\text { (<1000Da) }\end{array}$ & $\begin{array}{l}\text { macrosolutes } \\
\text { and colloids }\end{array}$ & $\begin{array}{l}\text { Separation of } \\
\text { molecular } \\
\text { mixtures }\end{array}$ \\
\hline $\begin{array}{l}\text { Nanofiltration } \\
\text { (NF) }\end{array}$ & $\begin{array}{c}\text { Asymmetric, } \\
\text { mesoporous } \\
\text { Pore radius } \\
0.5-2 \mathrm{~nm}\end{array}$ & $\begin{array}{c}\text { Hydrostatic } \\
\text { pressure } \\
0.3-3 \mathrm{MPa} \\
(3-30 \mathrm{bar})\end{array}$ & $\begin{array}{l}\text { Size } \\
\text { exclusion, } \\
\text { diffusion, } \\
\text { Electrical } \\
\text { charge of } \\
\text { particle }\end{array}$ & Liquid & Liquid & $\begin{array}{c}\text { solvent } \\
\text { (water), low } \\
\text { molecular } \\
\text { weight } \\
\text { solutes, } \\
\text { monovalent } \\
\text { ions }\end{array}$ & $\begin{array}{l}\text { molecular } \\
\text { weight } \\
\text { compounds } \\
>200 \mathrm{Da}, \\
\text { multivalent } \\
\text { ions }\end{array}$ & $\begin{array}{l}\text { Separation of } \\
\text { molecular } \\
\text { mixtures and } \\
\text { ions }\end{array}$ \\
\hline $\begin{array}{l}\text { Reverse } \\
\text { Osmosis } \\
\text { (RO) }\end{array}$ & $\begin{array}{l}\text { Asymmetric } \\
\text { skintype, } \\
\text { dense or } \\
\text { microporous } \\
\text { Pore Radius } \\
<1 \mathrm{~nm}\end{array}$ & $\begin{array}{c}\text { Hydrostatic } \\
\text { pressure } \\
1-10 \mathrm{MPa} \\
(10-1000 \\
\text { bar) }\end{array}$ & $\begin{array}{c}\text { Solution } \\
\text { diffusion } \\
\text { mechanism }\end{array}$ & Liquid & Liquid & $\begin{array}{l}\text { solvent } \\
\text { (water) }\end{array}$ & $\begin{array}{l}\text { dissolved } \\
\text { and } \\
\text { suspended } \\
\text { solids }\end{array}$ & $\begin{array}{c}\text { Sea \& } \\
\text { brackish water } \\
\text { desalination }\end{array}$ \\
\hline $\begin{array}{l}\text { Electrodialysis } \\
\text { (ED) }\end{array}$ & $\begin{array}{l}\text { Symmetric lon- } \\
\text { exchange } \\
\text { membrane }\end{array}$ & $\begin{array}{l}\text { Electrical } \\
\text { potential }\end{array}$ & $\begin{array}{c}\text { Electrical } \\
\text { charge of } \\
\text { particle }\end{array}$ & Liquid & Liquid & $\begin{array}{l}\text { solutes } \\
\text { (ions), small } \\
\text { quantity of } \\
\text { solvents }\end{array}$ & $\begin{array}{l}\text { non-íonic } \\
\text { and macro- } \\
\text { molecular } \\
\text { species }\end{array}$ & $\begin{array}{c}\text { Water } \\
\text { desalination }\end{array}$ \\
\hline $\begin{array}{l}\text { Dialysis } \\
\text { (D) }\end{array}$ & $\begin{array}{l}\text { Symmetric } \\
\text { porous }\end{array}$ & $\begin{array}{c}\text { Concentration } \\
\text { gradient }\end{array}$ & Diffusion & Liquid & Liquid & $\begin{array}{c}\text { solute (ions } \\
\text { and low } \\
\text { MW } \\
\text { organics), } \\
\text { small } \\
\text { solvent } \\
\text { quantity }\end{array}$ & $\begin{array}{l}\text { dissolved } \\
\text { and } \\
\text { suspended } \\
\text { solids with } \\
\mathrm{MW} \\
>1000 \mathrm{Da}\end{array}$ & $\begin{array}{l}\text { Artificial } \\
\text { kidney }\end{array}$ \\
\hline $\begin{array}{l}\text { Membrane } \\
\text { distillation } \\
\text { (MD) }\end{array}$ & $\begin{array}{l}\text { Symmetric } \\
\text { porous } \\
\text { hydrophobic }\end{array}$ & $\begin{array}{c}\text { Temperature } \\
\text { gradient and } \\
\text { Vapor } \\
\text { pressure }\end{array}$ & Diffusion & Liquid & Liquid & volatiles & non-volatiles & $\begin{array}{c}\text { Water } \\
\text { desalination, } \\
\text { concentration } \\
\text { of solutions }\end{array}$ \\
\hline $\begin{array}{l}\text { Membrane } \\
\text { Contactors } \\
\text { (MC) }\end{array}$ & Various & $\begin{array}{l}\text { Chemical } \\
\text { potential }\end{array}$ & $\begin{array}{l}\text { Diffusion and } \\
\text { solution }\end{array}$ & $\begin{array}{l}\text { Gas I } \\
\text { Liquid }\end{array}$ & Liquid & $\begin{array}{l}\text { Compounds } \\
\text { soluble in } \\
\text { the } \\
\text { extraction } \\
\text { solvent, } \\
\text { volatiles }\end{array}$ & $\begin{array}{l}\text { compounds } \\
\text { non-soluble } \\
\text { in the } \\
\text { extraction } \\
\text { solvent, non- } \\
\text { volatiles }\end{array}$ & $\begin{array}{l}\text { Separation of } \\
\text { molecular } \\
\text { mixtures, } \\
\text { purification, } \\
\text { etc. }\end{array}$ \\
\hline
\end{tabular}




\subsubsection{Membrane Modules}

Configurations for membranes, Figure 3.3, in water and wastewater treatment applications are based on planer or cylindrical geometries. They comprise of plate and frame or flat sheet/plate (FS), hollow fibre (HF), multi-tubular (MT), capillary tube (CT), pleated filter cartridge (FC) and spiralwound (SW). The direction of filtration flow and permeate flow of the various element is shown in Figure 3.2. From Table 3.2 a comparison of some of the different membrane module configurations.

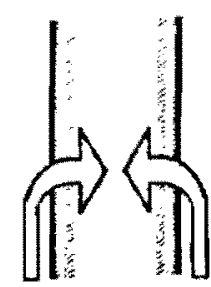

(a) Flat Sheet

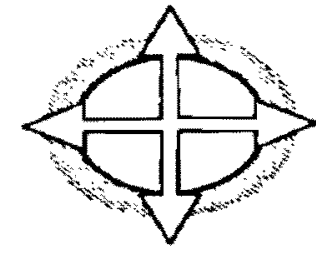

(b) Hollow Fiber

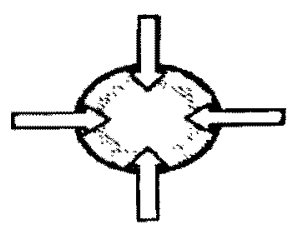

(c) Multi-Tubular

Figure 3.2 Typical types of membrane modules showing the direction of liquid flow (source: Judd S., 2006)

Table 3.2. Comparison of some of the different membrane module configurations (adapted from: Baker R.W., 2000; Nunes S.P. and Peinemann K.V., 2006; Judd S., 2006; AWWARF, 1996; Zeman L.J., 1996)

\begin{tabular}{|c|c|c|c|c|c|}
\hline Configuration & $\begin{array}{c}\text { Particulate } \\
\text { Plugging }\end{array}$ & $\begin{array}{c}\text { Permeate } \\
\text {-side } \\
\text { pressure } \\
\text { drop }\end{array}$ & $\begin{array}{c}\text { Ease of } \\
\text { Cleaning }\end{array}$ & $\begin{array}{c}\text { Energy } \\
\text { costs } \\
\text { (pumping) }\end{array}$ & $\begin{array}{c}\text { सanufacture }_{\text {Cost }} \\
\left(\text { US } \$ \mathbf{m}^{2}\right)\end{array}$ \\
\hline Flat plate & Moderate & Low & Good & Moderate & $50-200$ \\
\hline Spiral wound & Very high & Moderate & Poor & Low & $5-50$ \\
\hline Hollow fibre & High & High & Fair & Moderate & $2-10$ \\
\hline Tubular & Low & Low & Excellent & High & $50-200$ \\
\hline
\end{tabular}

* Cost is dated from the year 2000 . 
(a) flat plate (or plate and frame)

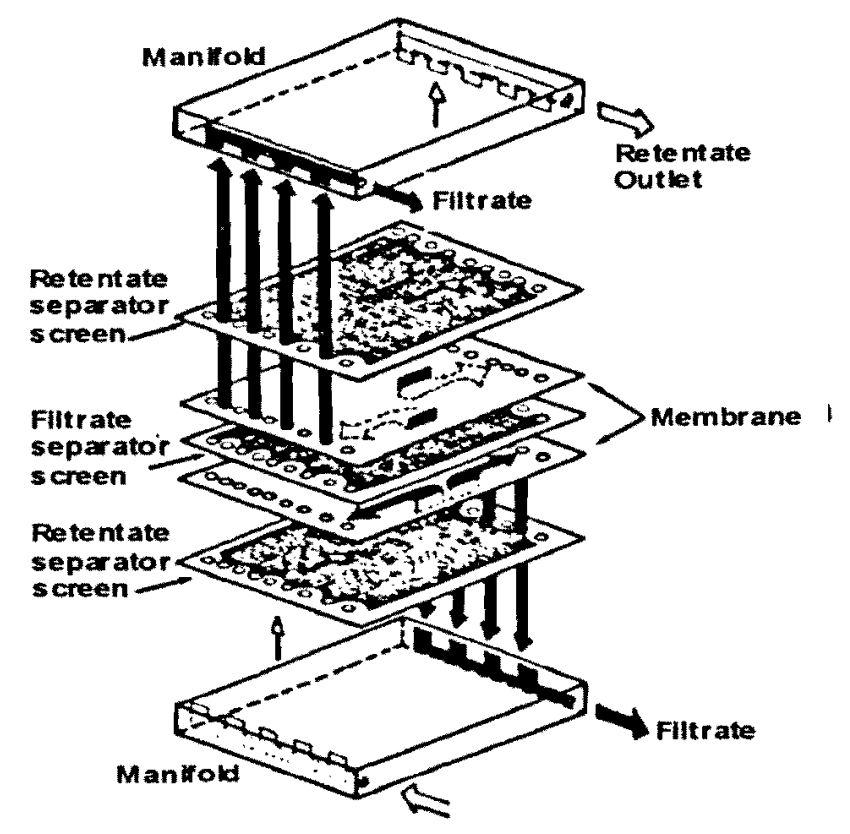

(c) hollow fibre

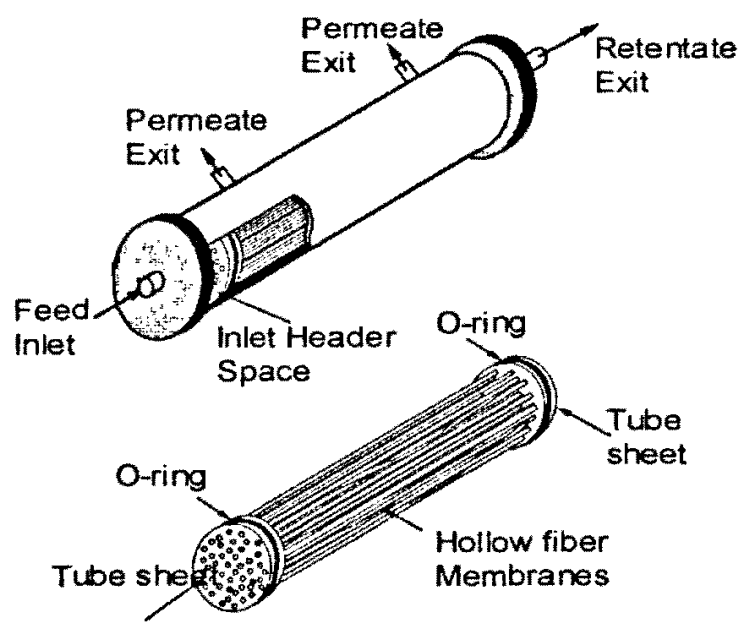

(b) spiral wound

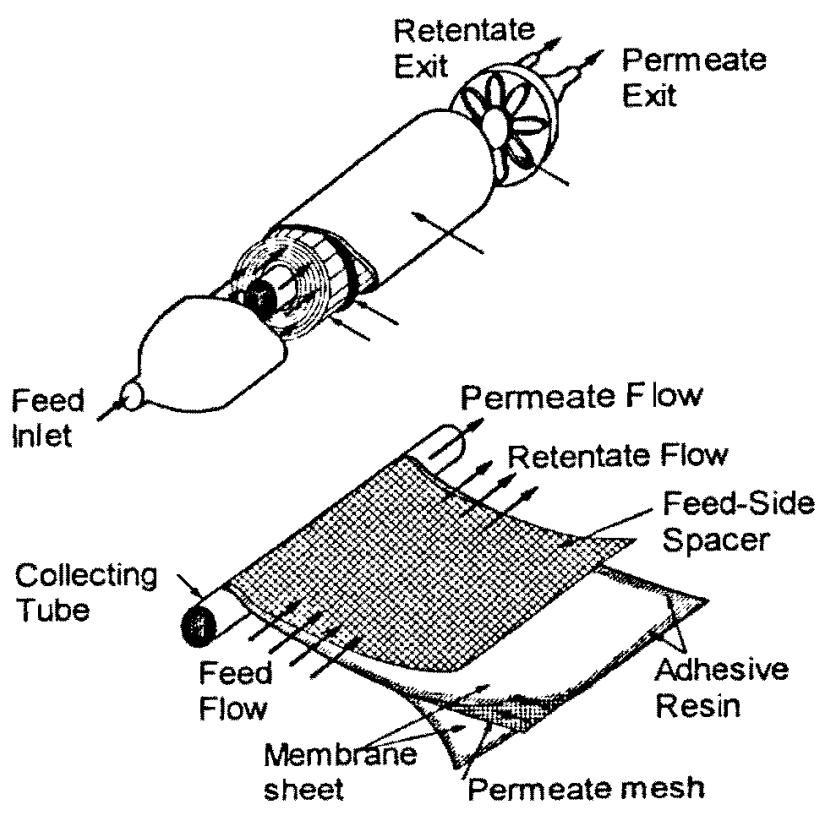

(d) tubular

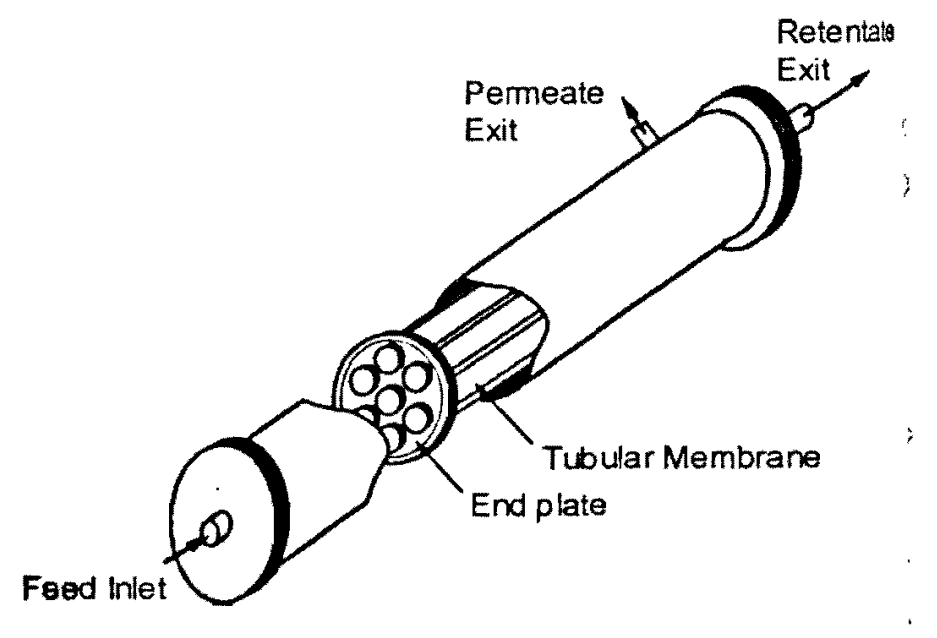

Figure 3.3 Schematic representations of the various membrane modules: (a) flat plate, (b) spiral wound, (c) hollow fibre and (d) tubular (source: Zeman and Zydney, 1996) 


\subsubsection{Membrane Materials}

Material used for membranes in water and wastewater separations cover a wide range, from organic polymers to inorganic materials (Table 3.3). Typically, the membrane would be fabricated to have high surface porosity (or percent total surface pore cross-sectional area) and narrow pore size distribution to provide as high a throughput and as selective a degree of rejection as possible. Along with structural integrity of the membrane, the membrane should normally have resistance to thermal and chemical attack (that is, extremes of temperature, $\mathrm{pH}$, or oxidant concentrations that normally arise when membranes are chemically cleaned), and should ideally offer some resistance to fouling.

Table 3.3 Various materials used for membrane fabrication of microfiltration and ultrafiltration processes (adapted from: Li N. et al., 2008)

\begin{tabular}{|c|c|c|}
\hline Membrane & \multicolumn{2}{|l|}{ Materials } \\
\hline Organic & \multicolumn{2}{|c|}{$\begin{array}{l}\text { Acrylonitrile polymer } \\
\text { Celullose acetate (celulose-2-acetate, cellulose-2-,5-diacetate, cellulose 3-acetate) } \\
\text { Cellulose nitrate (CN) } \\
\text { Mixed cellulose esters } \\
\text { Regenerated cellulose } \\
\text { Nylon } \\
\text { Polyamide (aromatic polyamide, copolyamide, polyamide hydrazide) } \\
\text { Polyacrylonitrile (PAN) } \\
\text { Polysulfone (PS) } \\
\text { Polyelectrolyte complexes } \\
\text { Polyester } \\
\text { Polyesther sulfone (PES) } \\
\text { Polycarbonate (track etched) } \\
\text { Polyethylene terephthalate (PET) (track etched) } \\
\text { Polyethylene (PE) } \\
\text { Polypropylene (PP) } \\
\text { Polytetrafluoroethylene (PTFE) } \\
\text { Polyvinylidene fluoride (PVDF) } \\
\text { Polytetrafluoroethylene (Teflon) } \\
\text { Polywinylchloride (PVC) }\end{array}$} \\
\hline Inorganic & $\begin{array}{l}\text { Alumina } \\
\text { Aluminum oxide }\left(\mathrm{Al}_{2} \mathrm{O}_{3}\right) \\
\text { Zirconia }\left(\mathrm{ZrO}_{2}\right) \text {-carbon } \\
\text { Zirconia }\left(\mathrm{ZrO}_{2}\right) \text {-polyacrylic acid } \\
\text { Titania }\end{array}$ & $\begin{array}{l}\text { Ceria }\left(\mathrm{CeO}_{2}\right) \\
\text { Glass }\left(\mathrm{SiO}_{2}\right) \\
\text { Stainless steel } \\
\text { Palladium }(\mathrm{PD}) \text { and its alloy }\end{array}$ \\
\hline
\end{tabular}


Polymeric membranes are the most widely used and the most practical material suitable for separation. Some examples of polymer membranes are polyvinylidene diflouride (PVDF), polyethylsulphone (PES), polyethylene (PE) and polypropylene (PP). These mentioned polymer materials have desirable physical properties (through specific manufacturing techniques) and reasonable chemical resistance.

Inorganic membrane materials such as ceramics, glass and metals are known to be rigid materials that consist of an infinite three-dimensional network of sintered crystalline grains comprising metals bonded to carbon, nitrogen or oxygen. Ceramic membrane materials can be oxides (alumina, titania, zirconia), non-oxides (carbides, borides, nitrides, silicides) or composites (particulate reinforced, combinations of oxides and non-oxides). The term ceramic generally applies to any class of inorganic, non-metallic product subjected to high temperature during manufacture or use (definition from International Union of Pure and Applied Chemists, IUPAC). Some advantages of ceramic membranes in comparison to other synthetic membranes are that they are more resistant to attack and fouling, have a lower maintenance cost, and operate at higher flux rates.

Ceramic membranes are used in separations where aggressive media, such as acids or strong solvents, are present. Some of the benefits of ceramic membranes are (Garmash et al., 1995):

$>$ excellent mechanical, thermal and chemical stability to shock and preserve their properties when heated and can operate at high pressures

$>$ Wide range of $\mathrm{pH}$ and long service life without deformation

$>$ Temperature range up to $250^{\circ} \mathrm{C}$

$>$ The higher cost of ceramic membranes, 3-5 times higher than polymeric material membranes, is compensated by their higher permeability, $20,000 \mathrm{~L} / \mathrm{h} \mathrm{m}^{2} \mathrm{MPa}$ instead of $5000 \mathrm{~L} / \mathrm{h} \mathrm{m}^{2} \mathrm{MPa}$

$>$ Longer lifetime, up to 10 years instead of 1 year for polymeric membranes

Ceramic membranes eliminate some limitations of polymer-based membranes. Replacement of polymeric membranes with ceramic membranes has eliminated preliminary cleaning of wastewaters. More about ceramic membranes will be discussed in Section 3.3. Proper selection of membranes can minimize membrane clogging and deterioration. 


\subsubsection{Theory of Filtration and Separation}

\section{Models describing water and solute flux through membranes}

Several models have been proposed explaining the transfer of solvent and rejection of solute by membranes. For microporous membranes (MF, UF) most agree that water moves across the membrane by advective transport. The rejected suspended particles are physically screened, or removed at the surface of the membrane, this known as sieving mechanism. The permeate flow is described by advective transport through the membrane pores where the pressure difference on either side of the membrane drives the transport. It is already well established by experimental evidence that water flux is proportional to the applied pressure across the membrane, and is inversely proportional to viscosity by the Darcy law.

In general, the water flux density, $\boldsymbol{j}_{w}$, through a membrane is defined as:

$$
j_{w} \equiv Q_{P} / A
$$

Equation 3.1

where $j_{w}=$ flux density of water through membrane $\left(\mathrm{m}^{3} / \mathrm{m}^{2} \cdot \mathrm{s}\right)$

$Q_{P}=$ flow rate of the filtered water $\left(\mathrm{m}^{3} / \mathrm{s}\right)$

$A=$ surface area of the membrane of the filtering module $\left(\mathrm{m}^{2}\right)$

The permeate flux or simply the flux, $J$, through the membrane is given by the general equation 3.2 , and is represented as $\mathrm{L} / \mathrm{m}^{2} / \mathrm{h}$.

$$
J=\frac{d V}{d t} \cdot \frac{1}{A_{M}}
$$

where $J=$ permeate flux $\left(\mathrm{m}^{3} / \mathrm{m}^{2} \cdot \mathrm{s}\right)$

$$
\begin{aligned}
V & =\text { filtered volume }\left(\mathrm{m}^{3}\right) \\
t & =\text { time }(\mathrm{s}) \\
A_{M} & =\text { membrane area }\left(\mathrm{m}^{2}\right)
\end{aligned}
$$

Transmembrane pressure, TMP, denoted as $\Delta P$, is defined as the difference in pressure between the two sides of the membrane, given in Equation 3.3a. For membrane units with a differential pressure along the feed side of the membrane equation $3.3 \mathrm{~b}$ is introduced.

$$
\begin{gathered}
\Delta P=P_{F}-P_{p} \\
\Delta P=\left[\left(P_{F}+P_{R}\right) / 2\right]-P_{p}
\end{gathered}
$$

Equation 3.3a

Equation $3.3 b$ 
where $P_{F}$ is the pressure of the feed water $(\mathrm{Pa}), P_{R}$ is the pressure of the retentate water $(\mathrm{Pa})$ and $P_{P}$ is the pressure of the permeate water $(\mathrm{Pa})$. The permeate flow may be controlled by an overflow weir or some means to maintain a positive pressure within the membrane element and thus reduce the incidence of gas precipitation (bubble formation).

The relationship between flux and TMP is proportional and can generally be used to describe the flux through unfouled membranes. A modified form of Darcy's law for laminar flow in porous media and is given in Equation 3.4 (Moulder, 1996, Crittenden et al., 2005)

$$
J=\frac{\Delta P-\Delta \pi}{\mu \cdot R_{\text {tot }}}
$$

Equation 3.4

where $\Delta P=$ pressure difference, $\operatorname{TMP}\left(\mathrm{N} / \mathrm{m}^{2}, \mathrm{~Pa}\right)$

$$
\begin{aligned}
\Delta \pi & =\text { osmotic pressure difference between the feed side and permeate side }\left(\mathrm{N} / \mathrm{m}^{2}, \mathrm{~Pa}\right) \\
\mu & =\text { dynamic viscosity }\left(\mathrm{N} \cdot \mathrm{s} / \mathrm{m}^{2}, \mathrm{~Pa} \cdot \mathrm{s}\right) \\
R_{t o t} & =\text { total resistance over membrane }(1 / \mathrm{m})
\end{aligned}
$$

Viscosity of the fluids (mixed liquor and permeate) affects the permeation flux rate (Equation 3.4). Viscosity is affected by the feed solution temperature. In addition viscosity changes with the solid concentration of the solution which changes with the degree of turbulence and velocity (i.e. crossflow) at the membrane surface. The term $(\Delta P-\Delta \pi)$ represents the driving force, where the TMP is reduced by the osmotic pressure difference that occurs due to solute rejection. $\Delta \pi$ is zero if the feed is a pure solvent.

The selectivity of the membrane is expressed as the retention (or rejection), $R$, and is given as

$$
R=1-\frac{C_{P}}{C_{F}}
$$

$$
\begin{aligned}
& \text { where } R=\text { retention (dimensionless) } \\
& \qquad \begin{array}{l}
C_{P}=\text { concentration in the permeate }\left(\mathrm{kg} / \mathrm{m}^{3}\right) \\
C_{F}=\text { concentration in the feedwater }\left(\mathrm{kg} / \mathrm{m}^{3}\right)
\end{array}
\end{aligned}
$$

For ultrafiltration (UF) membranes typically have pore size in the range of $100-1 \mathrm{~nm}(0.1$ - 
$0.001 \mu \mathrm{m})$. This permeability-based membrane separation technique is used for processing yeast cells, bacteria, some viruses and macromolecules such as proteins, nucleic acids and polysaccharides that have particle or molecular diameter, $d_{p}$ in the range of $100-5 \mathrm{~nm}(0.1-0.005$ $\mu \mathrm{m})$. The main separation mechanism for UF is relied on size-based sieving or size-exclusion. Other factors such as electrostatic solute-membrane and solute-solute interactions can affect separation. The role of non-size-based factors in ultrafiltration increases the scope of application and should be taken into account and properly utilized. Therefore, the fact that separation depends on a large number of factors means that process optimization is essential.

Table 3.4 Primary operational characteristics of membrane filtration processes (adapted from: Weber, 1972; Crittenden et al., 2005; Asano et al. 2007)

\begin{tabular}{|c|c|}
\hline Operational Parameter & Ultrafiltration \\
\hline Separation principle & Size, charge \\
\hline Size of species separated $(\mu \mathrm{m})$ & $0.001-0.2$ \\
\hline Molecular weight cut-off value & $500-500,000$ \\
\hline Typical recovery $(\%)$ & $80-98$ \\
\hline Operating pressures $(\mathrm{bar})$ & Up to 10 \\
\hline Typical flux $\left(\mathrm{m}^{3} /\right.$ day $\left./ \mathrm{m}^{2}\right)$ & $0.2-3$ \\
\hline Crossflow-velocity $(\mathrm{m} / \mathrm{s})$ & $0.2-2$ \\
\hline
\end{tabular}

The pressure-driven ultrafiltration process retain colloids, particulates and high-molecular-mass soluble species through a mechanism of size exclusion, and, provides a means for concentrating, fractionating, or filtering dissolved or suspended species. UF generally allows most ionic inorganic species to pass and retains discrete particulate matter and non ionic and ionic organic species, depending on the molecular weight cutoff (MWCO) of the membrane. The MWCO is a specification (used by manufacturers) describing the retention capabilities of a membrane referring to the molecular mass of a macrosolute (typically, polyethylene glycol, dextran or protein) for which the membrane has a retention capability greater than $90 \%$.

Colloids are macromolecules in aqueous dispersion described by an effective size, anything up to $0.2 \mu \mathrm{m}$. Particulates of microorganism and biological cells, both living and dead (cell debris), range 
in the size of $1-20 \mu \mathrm{m}$.

The productivity is a main issue in UF. Productivity is quantified in terms of the permeate flux, this defined as the permeation rate per unit membrane surface area. The volumetric permeate flux, which is the volume of permeate collected per unit time per unit membrane area is given by the generalized equation 3.4 based on the resistance model. Another equation to obtain permeate flux is by concentration polarization based on solutes is discussed in Chapter 5 .

To achieve high permeate flux, optimization of parameters that affect the permeate flux must be carried out. That is, reducing concentration polarization and fouling by techniques such as periodic backflushing, creation of turbulence on the feed side or introducing gas bubbles. 


\subsection{Membrane Technology Application}

There is a rapid growth of membrane filtration design and applications due to modern conceptual improvements of this technology. In the wastewater industry, membrane technology can be applied in a membrane bioreactor (MBR) or as a tertiary membrane filtration (TMF) unit, see Figure 3.4. The difference between the two applications is that for a TMF the membrane is applied at the end of a secondary treatment as an independent unit to further treat the clarified effluent. The membrane applied in an MBR seeks to replace the clarifier, acting as one unit with the biological process. In either case, the choice of membrane basically depends on the desired effluent standards. A relative comparison of the two process configurations is shown in Table 3.5 .

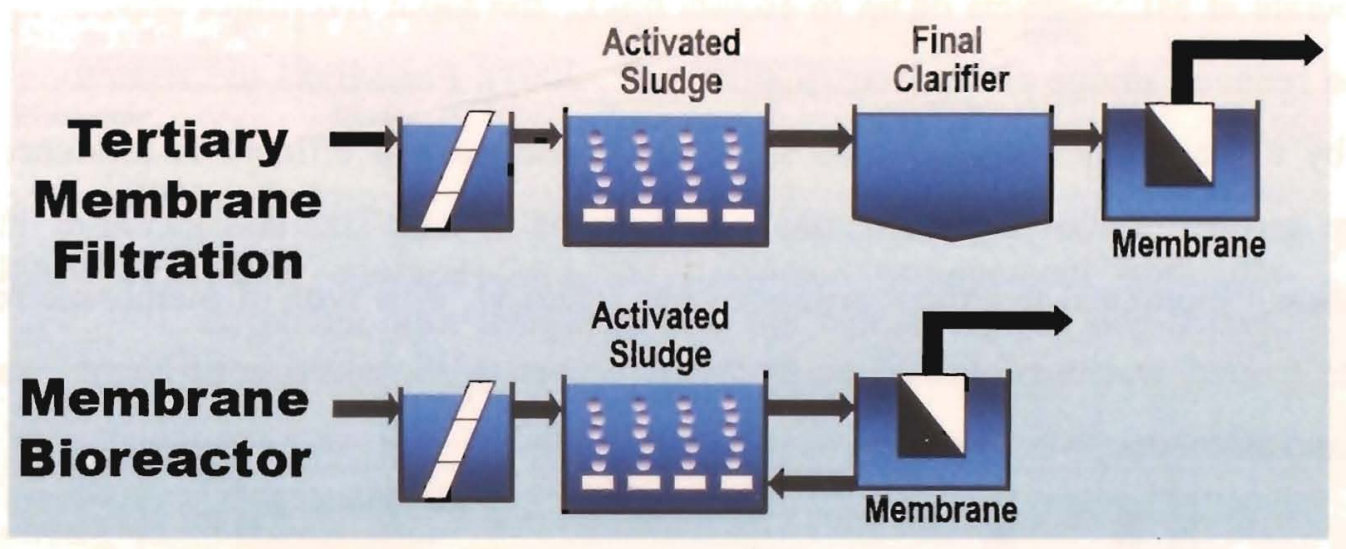

Figure 3.4 Process configurations of two different membrane treatment trains (source: WEF Webcast, 2009)

Table 3.5 Relative comparison of TMF and MBR (source: WEF Webcast, 2009)

\begin{tabular}{|c|c|c|}
\hline & $\begin{array}{c}\text { Tertiary Membrane } \\
\text { Filtration }\end{array}$ & $\begin{array}{c}\text { Membrane } \\
\text { Bioreactor }\end{array}$ \\
\hline Land use Required & 3 times & 1 \\
\hline Number of Processes to Operate & 2 (AS, Filter) & 1 (MBR) \\
\hline Effluent Quality/Pathogen Removal & Excellent & Excellent \\
\hline Unstaffed Operations Potential & Low & High \\
\hline Capital Cost* & $\$-\$ \$$ & $\$$ \\
\hline Operating Cost* & $\$$ & $\$ \$$ \\
\hline Biological Process Solids Concentration (g/L) & $1-4$ & $8-12$ \\
\hline Solids Concentration at Membrane $\mathbf{( g / L )}$ & $\sim 0.01$ & $8-12$ \\
\hline Ease of Biological Nutrient Removal & Easy & Medium \\
\hline
\end{tabular}

* where ' $\$$ ' means a moderate cost price and ' $\$ \$$ ' means an expensive cost price. 
When a biological treatment process is combined with a membrane separation process, this incorporation (of bioreactors and membranes) is termed membrane bioreactors (MBR). The MBR process seeks to replace the clarification/sedimentation and filtration stages of a conventional wastewater treatment arrangement. The MBR incorporates a biological stage and a physical separation stage that serve a specific function: biological degradation of organic pollution is carried out in the bioreactor by adapted microorganisms; and separation of microorganisms from the treated wastewater is performed by the membrane module. The disadvantages of the conventional arrangements for secondary treatment are the limitations in process performance and efficiency, such as sludge settleability, extent and rate of variability in hydraulic or organic loading, with a limited mixed liquor suspended solids (MLSS) concentrations of less than 3,500 mg/L. The MBR may operate at MLSS levels of up to $16,000 \mathrm{mg} / \mathrm{L}$, are about five times smaller in foot print and result in reduced sludge production (Mallia et al., 2001). For MBRs the separation or rejection of solids by a membrane, clarified and substantially disinfected effluent is produced, driven by a pressure gradient across the membrane. Reductions in tank size and increases in efficiency of conventional biological treatment processes are achieved. This type of membrane reactor tends to generate treated waters of higher purity with respect to dissolved constituents, such as organic matter and ammonia.

With further MBR advances, progress of membrane technology and applications may lead to the eventual future replacement of tertiary treatment steps, with solid/liquid separation in the biological treatment processes and the sedimentation step eliminated (Visvanathan et al., 2000).

TMF, Tertiary Membrane Filtration is an advanced technology for filtration and disinfection of wastewater effluent. An improved phosphorous reduction with separate secondary and tertiary processes can be achieved. The TMF is flexible to existing treatment processes by extension of current operation units/trains and does not take a significant amount of space when compared to MBR. The membranes applied to either TMF or MBR is typically a microfiltration or ultrafiltration membrane module. The membranes may be immersed (submerged) or external, see Figure 3.5. The permeate flow of a submerged membrane would be by suction or a vacuum pump. In the case when aeration is applied to membranes submerged in a tank, the uplifting air within the tank provides shear forces at the membrane surface in an effort to remove cake build-up. Hence, air flow velocity 
and cycling frequency of the suction pump are important operating parameters to maintain an adequate flux. One of the drawbacks of the immersed membrane configuration is that because the permeation is by mechanical suction forces (i.e., vacuum pump) the pressure available by the pump is limited to a maximum of 10.3 meter of head or $0.996 \mathrm{~atm}$.

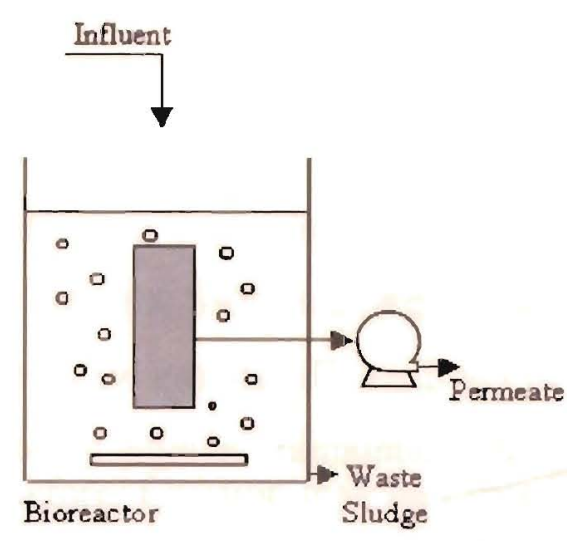

(a)

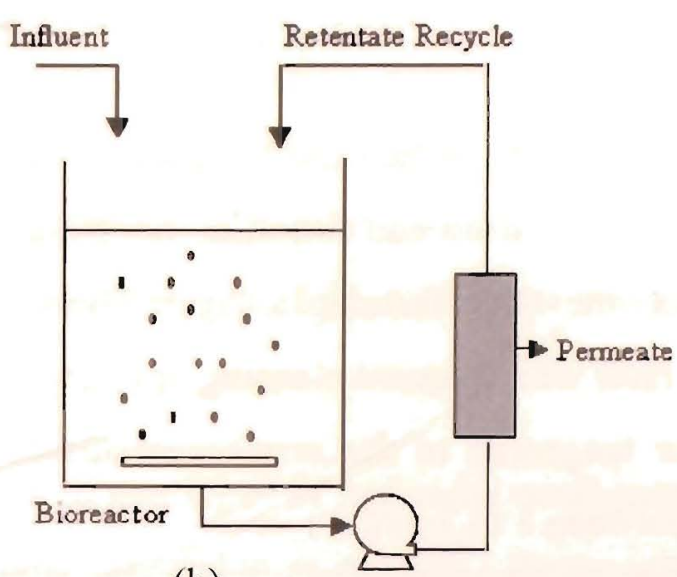

(b)

Figure 3.5 MBR configurations (a) immersed arrangement with the membrane unit integrated into the bioreactor; (b) side-stream arrangement with a separate membrane filtration unit

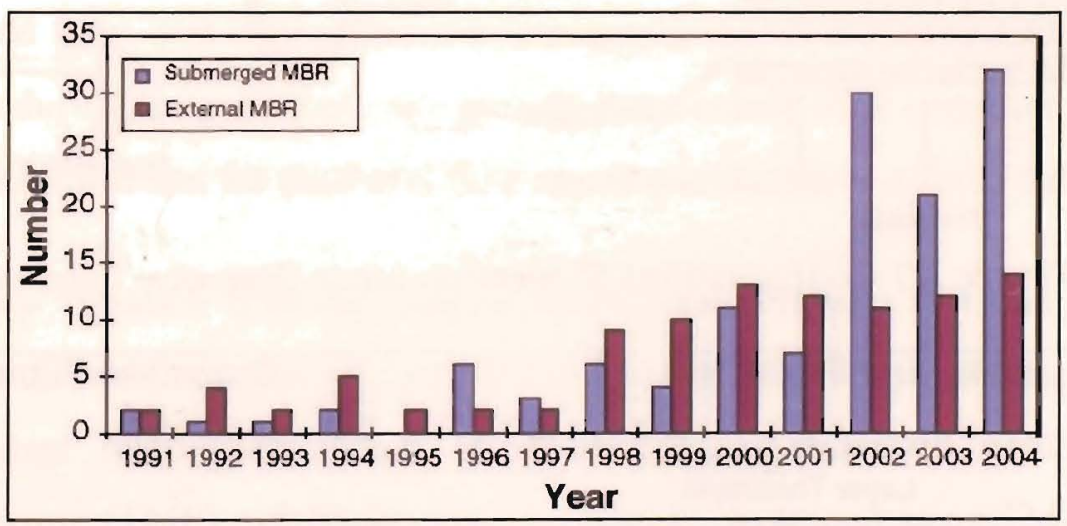

Figure 3.6 Distribution of studies on submerged and external membrane bioreactors (Yang et al., 2006).

Therefore this leaves the permeate flux limited under this condition. For the side-stream configuration, the cross-flow velocity and operating pressure generated by the pump are the vital factors for adequate flux. Immersed membranes are generally known to be less-energy intensive than the external set-up, since this type of set-up employs a suction pump in which a limited suction pressure is available. Membrane modules in a pumped side-stream configuration, incurs an energy 
penalty due to higher pressure that can be applied. To make the most use of a membrane, the flow path length would be as long as possible, such that maximum intrinsic energy in the liquid flowing at high pressure is used for permeation. Therefore, an external side-stream design would allow this dimensional advantage versus a membrane that is submerged in a tank. From the Figure 3.6, the application of research distribution between the two configurations is shown until 2004, where a propelled distribution since 2002 of submerged MBR studies is revealed.

Cross-flow filtration is widely used versus the dead-end process, see Figure 3.7 and Figure 3.8. During conventional dead-end filtration, the filtrate flow or flux decreases rapidly as the particles accumulate on the filter forming a layer. The continuous particle layer build-up results in low overall flow rates with frequent cleaning or changing of the filter. The alternative method is to apply the feed flow tangential to the membrane surface while maintaining a high velocity (controlled capabilities between 1 to $3 \mathrm{~m} / \mathrm{s}$ ).

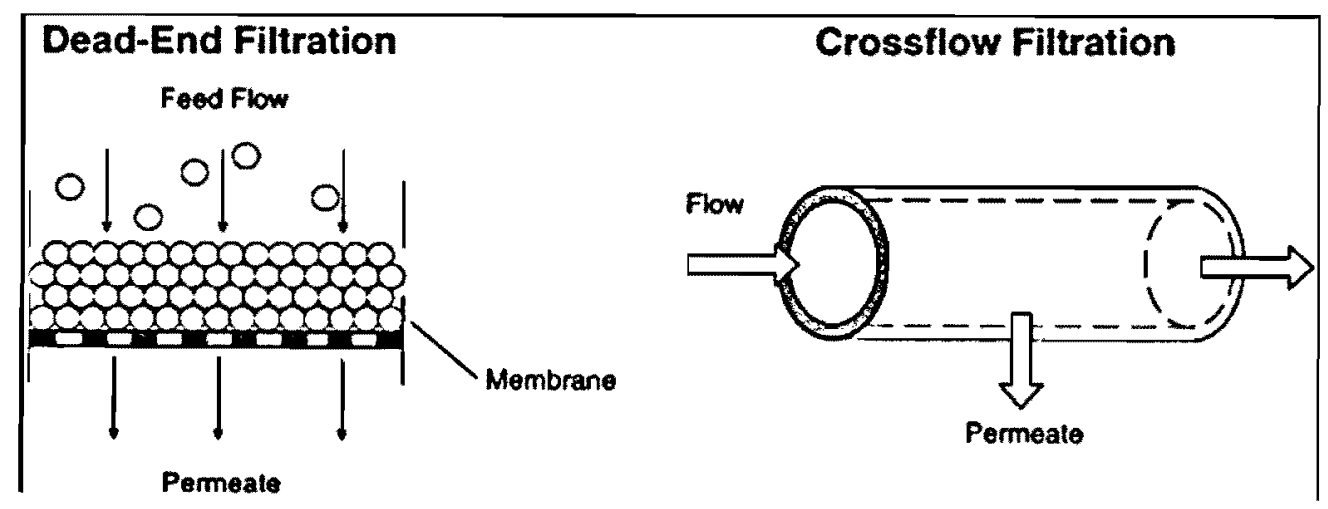

Figure 3.7 Configurations of filtration mode (Innovative Technology, 1998)

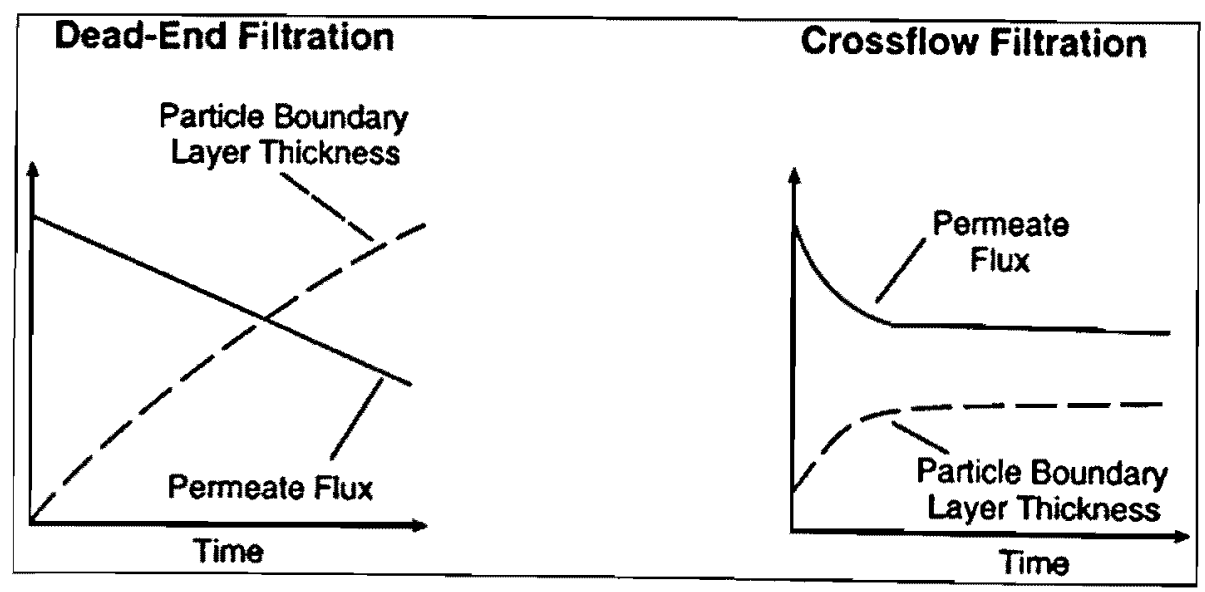

Figure 3.8 Conceptual comparisons of flux rates and particle boundary layer thickness (Innovative Technology 1998) 
General operation of membrane processes can be applied as constant pressure or constant flux filtration. Full-scale applications normally operate with constant-flux, rising pressure conditions because of production capacity requirements. On the other-hand, laboratory studies sometimes perform constant-pressure operation with declining flux mode which can support equipment capabilities and data analysis procedures.

An external membrane unit with continuous feed in a crossflow pattern, opposed to a submerged configuration, is seen to be accessed more easily. Since the external membrane unit would act independently from the bioreactor, influences of biodegradation and conversions would be free from disturbances of separation (e.g. biomass flow patterns) than if the membrane was submerged in the bioreactor.

As shown before, filtration may be carried out in two types of hydraulic configurations, crossflow (also referred to as tangential) and deadend (also referred to as normal). However, at the industrial scale crossflow processes are more usually preferred as an increase in the service life of the filtering element is observed (Garmash et al., 1995). During crossflow filtration the feed flow is tangential to the filter medium. The thickness of the deposit (cake) formed is limited by the shear forces imparted by the feed flow, and so the pressure loss across the cake is also limited. The permeate flow rate decreases during the period of cake growth, but a steady state condition is reached and the cake thickness is stabilized and the permeate flow rate is maintained at a finite value.

The aim of crossflow filtration is to establish an economical permeate flux that can be maintained over a period of time. With increases of crossflow velocity, the cake-layer forming materials can be swept away. A linear relationship exists at initial stage of filtration between the flux and transmembrane pressure (TMP), see Figure 3.9 (a). Initially with increasing TMP, increases in flux continue, but when the flux increases above the pressure dependent region, a pressure independent region is reached where the flux does not change. This is dictated by cake layer formation. Variable crossflow velocities, Figure 3.9 (b), influence the flux rate. 


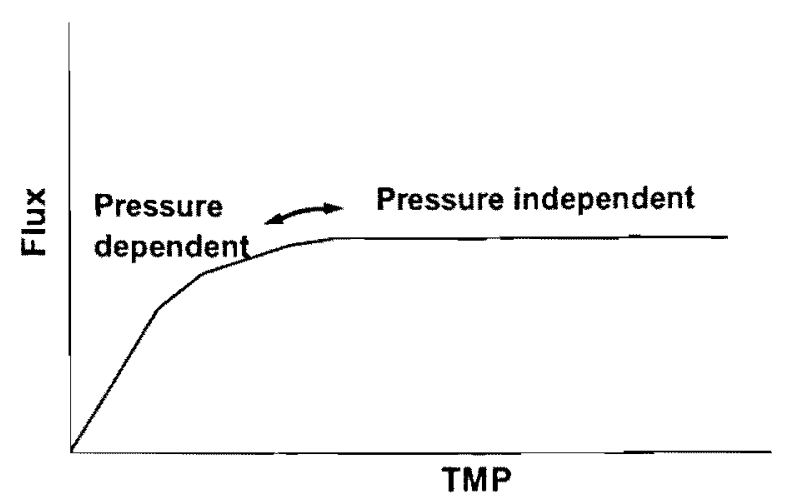

(a)

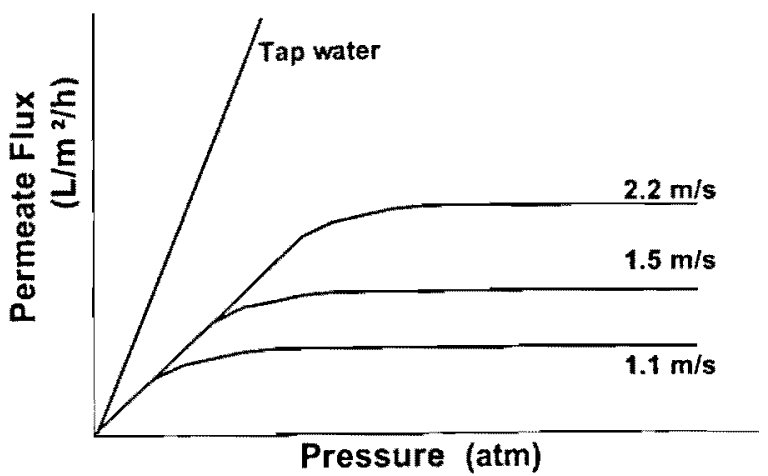

(b)

Figure 3.9 Representation of flux versus transmembrane pressure for membrane filtration (a) with cake formation and (b) at various velocities (adapted from: Visvanathan et al., 2000).

Transmembrane pressure, resistances of the membrane and resistances of the cake layer affect membrane filtration performance. The total resistance is a function of the resistance of membrane, polarization layer, and external resistance which is a combination of the physiochemical interactions of solids with the membrane and internal resistance due to materials absorbed into the pores. Proper selection of the pressure will overcome membrane and fouling resistances. Lower pressures result in lower compaction forces thus improving flux restoration, minimizing flux deterioration, and increasing membrane life (Asano et al., 2007).

An important implication of a membrane unit's hydraulic configuration is its impact on the degree to which suspended solids are concentrated on the feed side of the membrane. This is characterized by the volumetric concentration factor (VCF), a dimensionless parameter that represents the ratio of the concentration of suspended solids on the feed side of the membrane relative to that of the influent feed to the membrane filtration process (U.S.EPA, 2005)

$$
V C F=\frac{C_{M}}{C_{F}}
$$

Equation 3.6

where $V C F=$ volumetric concentration factor (dimensionless)

$C_{M}=$ concentration of suspended solids maintained on the feed side of the membrane (number or mass / volume)

$C_{F}=$ concentration of suspended in the influent feed water to the membrane unit (number or mass / volume)

By definition, the VCF is equal to 1 for a system that does not concentrate suspended solids on the 
feed side of the membrane (i.e. $C_{M}=C_{F}$ ); these are defined as deposition mode systems. However, some hydraulic configurations concentrate suspended solids on the feed side of the membrane to degrees much greater than the influent feed concentration, with a corresponding VCF greater than one; these are the suspension mode systems. 


\subsection{CERAMIC MEMBRANES}

\section{Ceramic Membranes}

As already mentioned, the ceramic membrane is used in separations where aggressive media are present owing to their excellent mechanical, thermal and chemical stabilities to shock, and to preserve their properties when heated while operating at high pressures and wide ranges of $\mathrm{pH}$. With most common applications limited to the food, beverage, and pharmaceutical industries, fast developments have been concentrated in environmental related applications such as, gas separations (particularly ionic conductors for oxygen transport) and molecular sieve membranes for hydrogen separation. Moreover, other environmental applications include the removal of colloidal, submicron or micron size suspended and dissolved particles from a wide range of fluids (e.g. wastewater, drinking water, industrial solvents and oils) with objectives to meet regulatory standards or to allow reuse and recycle of the fluids. Some reported benefits of ceramic membranes are as follows (Mempro, 2005):

- Long and reliable lifetime

- High resistance to temperature and pressure

- Rigid with no creep or deformation

- Stable over a wide $\mathrm{pH}$ range

- Corrosion \& abrasion resistant

- Insensitive to bacterial action
- Repeatedly sterilized by steam or chemicals

- Consistent pore size

- Can process highly viscous fluids

- Possibility of regeneration after fouling

- Membranes bonded to substrate by strong ceramic bonds

- Ability to be backwashed

The main strengths of ceramic membranes are: (1) high thermal stability, (2) a fine chemical stability and biocompatibility, and (3) good erosion resistance and non-compactability. These properties enable them to be used in more harsh environments than polymeric membranes and it permits more rigorous cleaning procedures, such as stronger cleaning agents, steam sterilization, backflushing, and ultrasonic cleaning. Moreover, ceramic membranes are less susceptible to microbial attacks and biological degradation and have a long life age. In some cases, they show catalytical or electrochemical activity. 
The weakness of ceramic membranes arises mainly from the manufacturing process, which makes it difficult to achieve a reproducible final product quality. This along with the intrinsically brittle character of ceramic membranes makes them always more expensive than polymeric membrane systems. Ceramic membranes have been quite high in costs (e.g., $\geq \$ 1,000 / \mathrm{m}^{2}$ versus about $\$ 100 / \mathrm{m}^{2}$ for polymeric counterparts) in comparison to polymeric membrane materials (Ciora and Liu, 2003). Moreover, the price of the membrane system rises substantially with increasing demands on such product properties as porosity, pore size, reproducibility, and reliability (Laitinen, 2002).

Most commercial ceramic membranes are in disc, plate or tubular configuration. Some of the prominent original or earlier research studies and companies into ceramic membranes were given by Garmash et al. (1995), they are:

Outotec (formerly known as Larox Corporation): manufactures industrial ceramic microfilters, Ceramec, for cake filtration of suspensions in the mining industry

Ceramesh: technology from Great Britain produces flat ceramic membranes and rolled and plane-frame elements (shaped on a ribbon or a metallic grid)

$>$ Du Pont: produces membranes for the separating of hydrogen from waste gases in petroleum processing (some others applications like pharmaceutical, food and biotechnology hold suppliers as: Alcoa, Osmonics, Hitrex Filter Dive, Norton)

Installation with ceramic membrane: by Societe de Ceramic Technique, Societe de Fabrication d'Elements Catalytiques (Carbosep) and Ceram Filter in France, Alcan in Great Britain, Sartorius and Zeuts in Germany, Velders in Belgium, and Isalators Ltd. And Hitto Lenkokko in Japan.

$>$ The Asahi Glass Firm: produces tubular and flat membranes from boroaluminosilicate glass and modules based on them for filtration and ozonation of water, and

$>$ Russian specialists engaged in tangential filtration on tubular ceramic filter element (TCFE) at NIIStroikeramika (Research Institute for Building Ceramics). 
Table 4.1 Various commercially available ceramic membranes (adapted from: AWWARF et al. 1996; Laitinen, 2002; Ciora et al. 2003).

\begin{tabular}{|c|c|c|c|c|c|}
\hline Manufacturer & $\begin{array}{l}\text { Trade } \\
\text { Names }\end{array}$ & $\begin{array}{l}\text { Membrane } \\
\text { Types }\end{array}$ & Geometries & Pore size / Cut-off & $\begin{array}{l}\text { Membrane } \\
\text { Material }\end{array}$ \\
\hline \multirow[t]{3}{*}{$\begin{array}{l}\text { Hermsdorfer Institut } \\
\text { für Technische } \\
\text { Keramik }\end{array}$} & & MF & & $\begin{array}{l}0.1-1.0 \mu \mathrm{m} \\
0.25 \mu \mathrm{m}, 0.4 \mu \mathrm{m} \\
0.11 \mu \mathrm{m}\end{array}$ & $\begin{array}{l}\text { a-alumina } \\
\text { titania } \\
\text { zirconia }\end{array}$ \\
\hline & & UF & & $\begin{array}{l}5.10 .60 \mathrm{~nm} \\
5.30 .60 \mathrm{~nm}\end{array}$ & $\begin{array}{l}\text { a/y-alumina } \\
\text { titania }\end{array}$ \\
\hline & & NF & & $\begin{array}{l}3.5 \mathrm{~nm} / 2.6 \mathrm{~kg} / \mathrm{mol} \\
0.9 \mathrm{~nm} / 0.45 \mathrm{~kg} / \mathrm{mol} \\
1.0,3 \mathrm{~nm} / 0.60,1.5 \mathrm{~kg} / \mathrm{mol}\end{array}$ & $\begin{array}{l}\text { zirconia } \\
\text { titania } \\
\text { silica }\end{array}$ \\
\hline Nihon Gaishi & & MF & $\begin{array}{l}\text { Tubular, } \\
\text { Multichannel }\end{array}$ & $0.2 .5 \mu \mathrm{m}$ & a-alumina \\
\hline $\begin{array}{l}\text { Process Media } \\
\text { Technology }\end{array}$ & & $\begin{array}{l}\text { MF } \\
\text { UF }\end{array}$ & $\begin{array}{l}\text { Tubular, } \\
\text { Multichannel }\end{array}$ & $\begin{array}{l}0.5 \text { to } 3 \mu \mathrm{m} \\
40 \AA \text { to } 0.2 \mu \mathrm{m}\end{array}$ & $\begin{array}{l}\alpha \text {-alumina } \\
a / \gamma \text {-alumina }\end{array}$ \\
\hline \multirow[t]{2}{*}{ Rhodia Orelis } & Carbosepe & $\begin{array}{l}\text { MF } \\
\text { UF }\end{array}$ & $\begin{array}{l}\text { Tubular, } \\
\text { multichannel }\end{array}$ & $\begin{array}{l}0.14 \mu \mathrm{m} \\
15,50.150 .300 \mathrm{~kg} / \mathrm{mol}\end{array}$ & $\begin{array}{l}\text { Support } \\
\text { carbon/Mem- } \\
\text { brane layer } \\
\text { zirconia-titania }\end{array}$ \\
\hline & Kerasep ${ }^{T M}$ & $\begin{array}{l}\text { MF } \\
\text { UF } \\
\text { NF }\end{array}$ & $\begin{array}{l}\text { Tubular, } \\
\text { multichannel }\end{array}$ & $\begin{array}{l}0.1,0.2,0.45,0.8 \mu \mathrm{m} \\
15,50,150,300 \mathrm{~kg} / \mathrm{mol} \\
1.5 \mathrm{~kg} / \mathrm{mol}\end{array}$ & $\begin{array}{l}\text { Support } \\
\text { Monolithic } \\
\text { alumina- } \\
\text { titania/Memb- } \\
\text { rane layer } \\
\text { zirconia or } \\
\text { titania }\end{array}$ \\
\hline \multirow[t]{6}{*}{ TAMI Industires } & DisRam & MF & Disk & $0.14,0.20,0.45,0.80,1.4 \mu \mathrm{m}$ & \\
\hline & INSIDE $\otimes$. & $\begin{array}{l}\text { UF } \\
\text { NF }\end{array}$ & & $\begin{array}{l}8,15,50,150,300 \mathrm{~kg} / \mathrm{mol} \\
1,3,5 \mathrm{~kg} / \mathrm{mol}\end{array}$ & \\
\hline & KéRAM & MF & Plate & $0.14,0.20,0.45,0.80,1.4 \mu \mathrm{m}$ & \\
\hline & INSIDE@ & UF & & $8,15,50,150,300 \mathrm{~kg} / \mathrm{mol}$ & \\
\hline & & NF & & $1,3,5 \mathrm{~kg} / \mathrm{mol}$ & \\
\hline & $\begin{array}{l}\text { CéRAM } \\
\text { INSIDE® }\end{array}$ & $\begin{array}{l}\text { MF } \\
\text { UF } \\
\text { NF }\end{array}$ & $\begin{array}{l}\text { Tubular, } \\
\text { multichannel }\end{array}$ & $\begin{array}{l}0.14,0.20,0.45,0.80,1.4 \mu \mathrm{m} \\
8,15,50,150,300 \mathrm{~kg} / \mathrm{mol} \\
1,3,5 \mathrm{~kg} / \mathrm{mol}\end{array}$ & $\begin{array}{l}\text { Support: } \\
\text { alumina/titanial } \\
\text { zirconial } \\
\text { Memrbane } \\
\text { layer: MF } \\
\text { zirconia, UF \& } \\
\text { NF titania }\end{array}$ \\
\hline USF (SCT) & Membralox(8) & $\begin{array}{l}\text { MF } \\
\text { UF } \\
\text { NF }\end{array}$ & $\begin{array}{l}\text { Tubular, } \\
\text { multichannel, } \\
\text { monolithic } \\
\end{array}$ & $\begin{array}{l}0.1-12 \mu \mathrm{m} \\
20-100 \mathrm{~nm} \\
1-5 \mathrm{~kg} / \mathrm{mol}\end{array}$ & $\begin{array}{l}\text { a-alumina } \\
\text { zirconia } \\
\text { titania }\end{array}$ \\
\hline
\end{tabular}


The development of ceramic membranes is mainly driven by the need to produce membranes with greater chemical and thermal tolerance, because the upper temperature limit of polymeric membranes is mostly below $200^{\circ} \mathrm{C}(\mathrm{Li}, 2007)$. In addition, most polymer membranes cannot survive in solvents such as benzene and toluene. Currently many new membrane companies have flourished. Various companies that manufacture ceramic membranes may be found in the Appendix A. Ciora et al., 2003, reported that for ceramic membranes the requirement to achieve high steady-state permeances were on the order of 150 to $200 \mathrm{~L} / \mathrm{m}^{2} /$ hour/bar. Zhong et al., 2003, found that treatment of oily wastewater using ceramic membrane filtration was done with the recommended operation conditions: transmembrane pressure of $0.11 \mathrm{MPa}$ and crossflow velocity of $2.56 \mathrm{~m} / \mathrm{s}$.

Visvanathan et al., 2000, showed that the selection of a membrane played an important role on the flux achieved and that a smooth surface membrane such as ceramics offer more resistance to cake layer adhesion, thus higher flux rates. As well, long lifetimes, the stability to withstand chemical and thermal shock, ability to withstand rigorous chemical cleaning, and high operating pressures, are well proven and among the reasons that one would want to choose ceramic versus other membrane materials. Zhong et al., 2003, reported that zirconia membranes were shown to have better separation performance as higher flux, less fouling and higher oil rejection. Li et al., 2008, reported that the surface of polymeric and ceramic membranes containing $\mathrm{TiO}_{2}$ on the outer skin layer, were found to be highly efficient in removing a number of organic contaminants and pathogenic microorganisms (in the presence of ultraviolet irradiation). The inactivation of bacteria and degradation of organic matter by $\mathrm{TiO}_{2}$ make membranes less vulnerable to organic and biological fouling. Although this is the case in regards to $\mathrm{TiO}_{2}$ membranes, it was difficult to obtain and an alumina membrane is to be used.

\section{Alumina}

Alumina is a synthetically produced aluminum oxide $\left(\mathrm{Al}_{2} \mathrm{O}_{3}\right)$. It is a white or nearly colourless crystalline substance used as a starting material for the smelting of aluminum metal. It also serves as the raw material for a broad range of advanced ceramic products and as an active agent in chemical processing.

Alumina is white in its powder form to use as ceramic material. With a chemical composition of 
$\mathrm{Al}_{2} \mathrm{O}_{3}$, its most common natural form is called corundum. Alumina appears in both a polycrystalline and a monocrystalline form, usually hexagonal known as alpha-alumina. The other from, cubic gamma-alumina is less stable. Alumina is not known to be very hazardous, this makes it a desirable material to use. Polycrystalline gamma-alumina can be made in a form that has many holes in it. These holes greatly enhance the surface of the material, making gamma-alumina a popular material to use as chemical catalysts.

Alpha-alumina is an extremely hard material, having a hardness of 9 on the Mohs scale (Mann et al., 2004), making it well suited for applications that require properties of being rigid, resistant to pressure and not easily scratched. Furthermore, alpha-alumina has excellent thermal properties. There are many ceramics with high melting points, and alpha-alumina's melting point is about $2027^{\circ} \mathrm{C}$. It also has a thermal conductivity of 30 Watt per meter per Kelvin $(\mathrm{W} / \mathrm{m} \cdot \mathrm{K})$ at room temperature. Compare this to plastics materials that have a thermal conductivity on the high end at $0.51 \mathrm{~W} / \mathrm{m} \mathrm{K}$ (Professional Plastics, 2010), making alpha-alumina popular in applications that must withstand extreme heat. Its ability to withstand temperature changes is further augmented by a specific heat of 77 Joule per kilogram per Kelvin $(\mathrm{J} / \mathrm{kg} \cdot \mathrm{K})$. 


\subsection{MEMBRANE FOULING AND CLEANING}

\subsection{Membrane Fouling and Concentration Polarization}

An important consideration in the design and operation of membrane equipment is permeate or filtrate flux as it affects pretreatment needs, cleaning requirements, operating conditions, cost and performance. A reduction of membrane flux below that of the corresponding pure water flux or pure solvent flux can be understood in two phenomena's: concentration polarization and fouling (see Table 5.1).

Table 5.1 Comparison of concentration polarization and membrane fouling characteristics.

\begin{tabular}{|c|c|c|}
\hline Characteristics compared & Concentration polarization (CP) & Membrane fouling \\
\hline Define & $\begin{array}{l}\text { Process in which solute or particles } \\
\text { accumulate as a thin layer adjacent to } \\
\text { the membrane surface due to a } \\
\text { concentration gradient }\end{array}$ & $\begin{array}{l}\text { Process in which solute or particles deposit } \\
\text { onto a membrane surface or into mernbrane } \\
\text { pores due to concentration polarization, such } \\
\text { that membrane performance is degraded }\end{array}$ \\
\hline Mechanism & $\begin{array}{l}\text { Deposition of cake formation, Gel } \\
\text { formation }\end{array}$ & $\begin{array}{l}\text { Adsorption, Pore biockage, Deposition, Gel } \\
\text { formation }\end{array}$ \\
\hline $\begin{array}{l}\text { Foulant transport from bulk } \\
\text { to surface of the fouling }\end{array}$ & Convection-diffusion & Advection \\
\hline $\begin{array}{l}\text { Measure of the extent of } \\
\text { the phenomena }\end{array}$ & $\begin{array}{l}\mathrm{CP} \text { modulus, the ratio of the component } \\
\text { concentration at the membrane to the } \\
\text { concentration in the bulk }\end{array}$ & $\begin{array}{l}\text { Average deposit surface loading, the ratio of } \\
\text { the weight of deposits to the surface area }\end{array}$ \\
\hline $\begin{array}{l}\text { Initial stage of fouling is } \\
\text { reversible and leads to }\end{array}$ & $\mathrm{CP}$ layer reversible & Irreversible fouling \\
\hline $\begin{array}{l}\text { Configuration mostly } \\
\text { affected }\end{array}$ & Cross-flow (tangential) & $\begin{array}{l}\text { Cross-flow (tangential), } \\
\text { Dead-end }\end{array}$ \\
\hline General model used & Film theory & Pore-flow \\
\hline Nature of the fouling & $\begin{array}{l}\text { High concentration of the rejected minor } \\
\text { component of a membrane process }\end{array}$ & $\begin{array}{l}\text { A mixture of components: inorganic, organic, } \\
\text { biological and particulate and colloidal or low } \\
\text { molecular }\end{array}$ \\
\hline $\begin{array}{l}\text { Types of concemed } \\
\text { substances/foulants }\end{array}$ & $\begin{array}{l}\text { Mostly inorganic salt contents in RO, } \\
\text { Colloidal in NF and UF } \\
\text { Suspended, colloidal and biological in } \\
\text { MF }\end{array}$ & $\begin{array}{l}\text { Particulate and colloidal (clays, flocs), } \\
\text { biological (bacteria, fungi), organic (oils, } \\
\text { polyelectrolytes, humics) and scaling } \\
\text { (mineral precipitates) }\end{array}$ \\
\hline $\begin{array}{l}\text { Major factors influencing } \\
\text { fouling interaction }\end{array}$ & $\begin{array}{l}\text { Charge, } \mathrm{pH} \text {, ionic strength of particles, } \\
\text { pressure, concentration, temperature, } \\
\text { solubility }\end{array}$ & $\begin{array}{l}\text { Charge, } \mathrm{pH} \text {, hydrophobicity, multivalent ions, } \\
\text { temperature, concentration, compressibility } \\
\text { of particles, solubility }\end{array}$ \\
\hline Interaction of foulants & Solute-solute at the surface & Solute-solute, solute-membrane, solute \\
\hline
\end{tabular}




\section{Concentration Polarization}

Concentration polarization is described by an accumulation of particles or solutes in a mass transfer boundary layer adjacent to the membrane surface (Peinemann, 2010). Dissolved molecules accumulate at the surface and reduce the solvent activity and this reduces the solvent flow through the membrane. High concentrations adjacent to the membrane surface of the feed side, produces an osmotic pressure gradient that opposes the externally applied pressure gradient. The external pressure applied is thus reduced and the flux decreases. This phenomenon is known to be reversible with an elimination of applied pressure. Concentration polarization occurs when the concentration (strength) of constituents along the membrane surface of the feed side increases higher than in the bulk of the feed solution passing in the channel. That is along the membrane surface fouling has occurred, hence concentration polarization is a resultant of fouling. This increase in concentration builds a layer along the membrane surface boundary forming a resistance layer.

The formation of a gel layer is another phenomenon that occurs. As the concentrations of components become high the solubility limits of those components are exceeded, and a solute forms a deposit layer, which acts as an extra hydraulic resistance. With limitations of osmotic pressure and gel formation, the flux becomes independent of pressure and reaches a plateau value.

The diagram in Figure 5.1 shows the solute concentration profile from the feed side, across the membrane to the permeate side. 


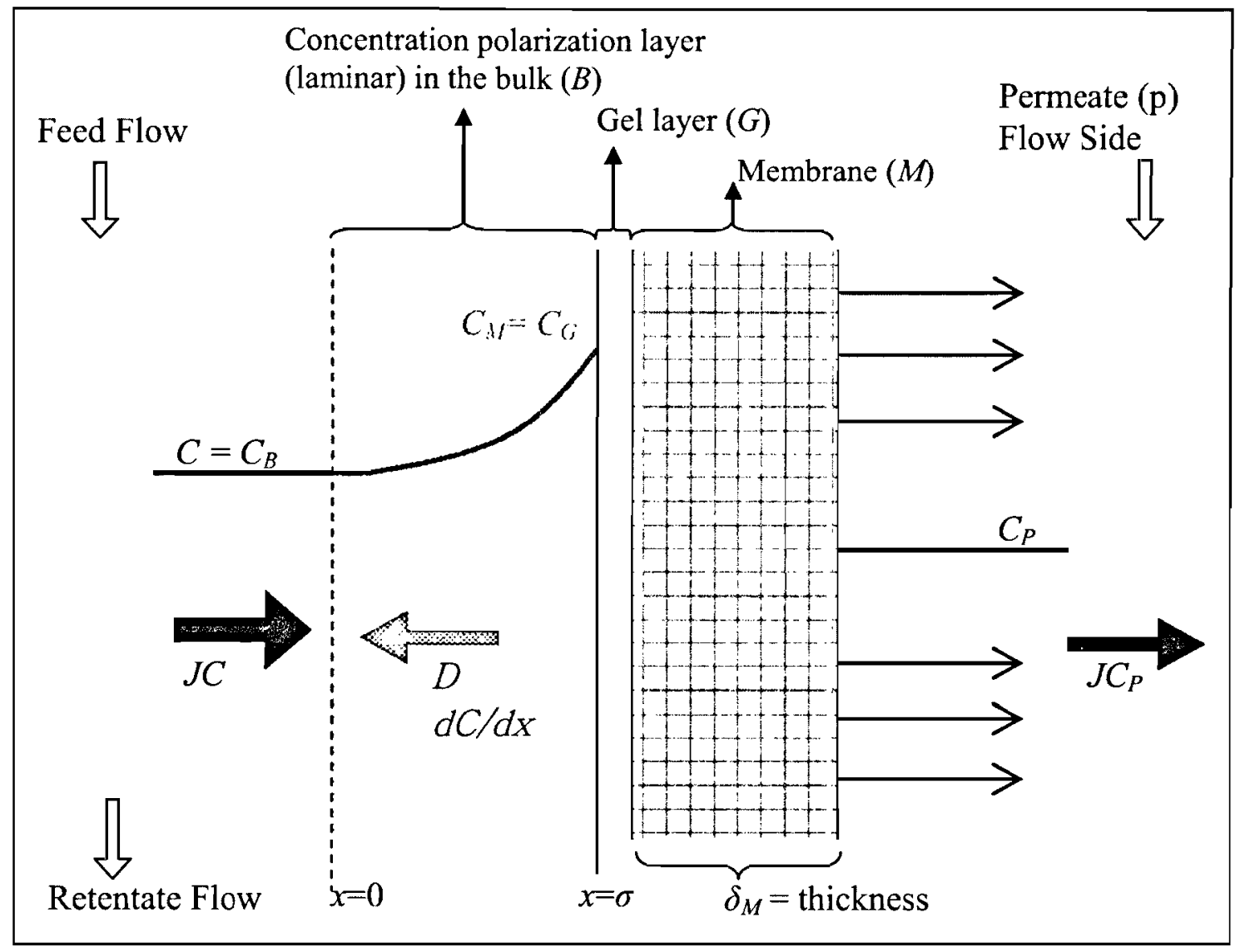

Figure 5.1 Concentration Polarization Layer, where $B$ is the bulk layer, $G$ the gel layer and $M$ is the membrane, $C$ is the concentration of the solute, $D$ is the diffusivity of the solute and $J$ is the flux and $p$ is the permeate or filtrate. (Adapted from: Deqian, 1987; Costa et al. 1991; Ibarz, 2003)

The mass balance on solute as follows:

$$
\begin{gathered}
{\left[\begin{array}{c}
\text { rate of } \\
\text { convection } \\
\text { towards the } \\
\text { membrane }
\end{array}\right]=\left[\begin{array}{c}
\text { rate of } \\
\text { diffusion } \\
\text { back into } \\
\text { the bulk } \\
\text { solution }
\end{array}\right]+\left[\begin{array}{c}
\text { rate of } \\
\text { permeation }
\end{array}\right]} \\
J C=D \frac{d C}{d x}+J C_{p}
\end{gathered}
$$

where $J=$ permeate flux

$C=$ solute concentration at the membrane surface

$D=$ solute diffusivity

$x=$ boundary layer thickness and

$C_{P}=$ solute concentration in the permeate stream. 
Equation 5.1 , is valid if:

$>$ diffusion coefficient is independent of concentration

$>$ concentration gradient is only in the polarization layer, assuming transfer from the solution to the layer is carried out by convective mechanisms

$>$ There is no convection stream due to density differences.

Rearranging Equation 5.1 gives,

$$
D \frac{d C}{d x}=J\left(C-C_{P}\right)
$$

Or rearranging

$$
\frac{d C}{\left(C-C_{P}\right)}=\frac{J}{D} d x
$$

Integrating from when $x=0, C=C_{B}$, where $C_{B}$ is the bulk concentration on the feed side, to when $x$ $=\sigma, C=C_{M}$ which is the concentration at the membrane or gel layer, and letting $D / \sigma=k$, where $k$ is the mass transfer coefficient of the solute gives the concentration at the membrane,

$$
C_{M}=C_{P}+\left(C_{B}-C_{P}\right) \exp (J / k)
$$

or the flux

Equation 5.3

$$
J=k\left(\frac{C_{M}-C_{P}}{C_{B}-C_{P}}\right)
$$

If $C_{P}$ is very small, then approximate $C_{P}=0$, for negligible amount of solute passing through the membrane, then

$$
C_{M}=\left(C_{B}\right) \exp (J / k)
$$

and

$$
J=k \ln \left(\frac{C_{M}}{C_{B}}\right)
$$

The flux is high when the ratio $C_{M} / C_{B}$ increases at a given mass transfer coefficient. Low fluxes occur with low values of $k$ or low diffusivity, $D$. Low values of $k$ or $D$ would occur from high solute molecular weight, or high solution viscosity, or large concentration polarization boundary layer thickness, $\sigma$. A large boundary layer thickness is a result of low turbulence. 


\section{Fouling}

The build-up of non-dissolved material (e.g. adsorbed macromolecules, gels, or deposited particles on or in the membrane surface) also reduces flux and is known to be fouling (Peinemann, 2010). Fouling may take on the following forms:

$>$ Adsorption, is when specific interactions between the membrane and the solute or particles exist. A monolayer of particles and solutes form and the pore radius is reduced inducing an increase in hydraulic resistance which causes a lower flux through the membrane.

Pore blockage is the closure or partial closure of the pores when filtering and leads to reduction in flux.

$>$ Deposition or also known as cake is when particles grow layer by layer at the membrane surface leading to hydraulic resistance (cake resistance).

$>$ Gel formation can form on the membrane surface, based on the level of concentration polarization and for certain macromolecules (e.g. a solution of concentrated proteins).

Fouling of membranes can be reversible or irreversible, that is, whether it can be removed from the surface of the membrane or not, see Figure 5.2. Gel layer formation is one form of fouling and reversible by rinsing with clean water. But fouling may become irreversible if the components in the gel layer react with one another to form a dense cross-linked layer on the surface of the feed side of the membrane. Consequently this layer is not easily removed and causes decrease in permeability. Adsorption at the pore wall also impacts the filtration performance. Pore blocking can also be highly irreversible. 


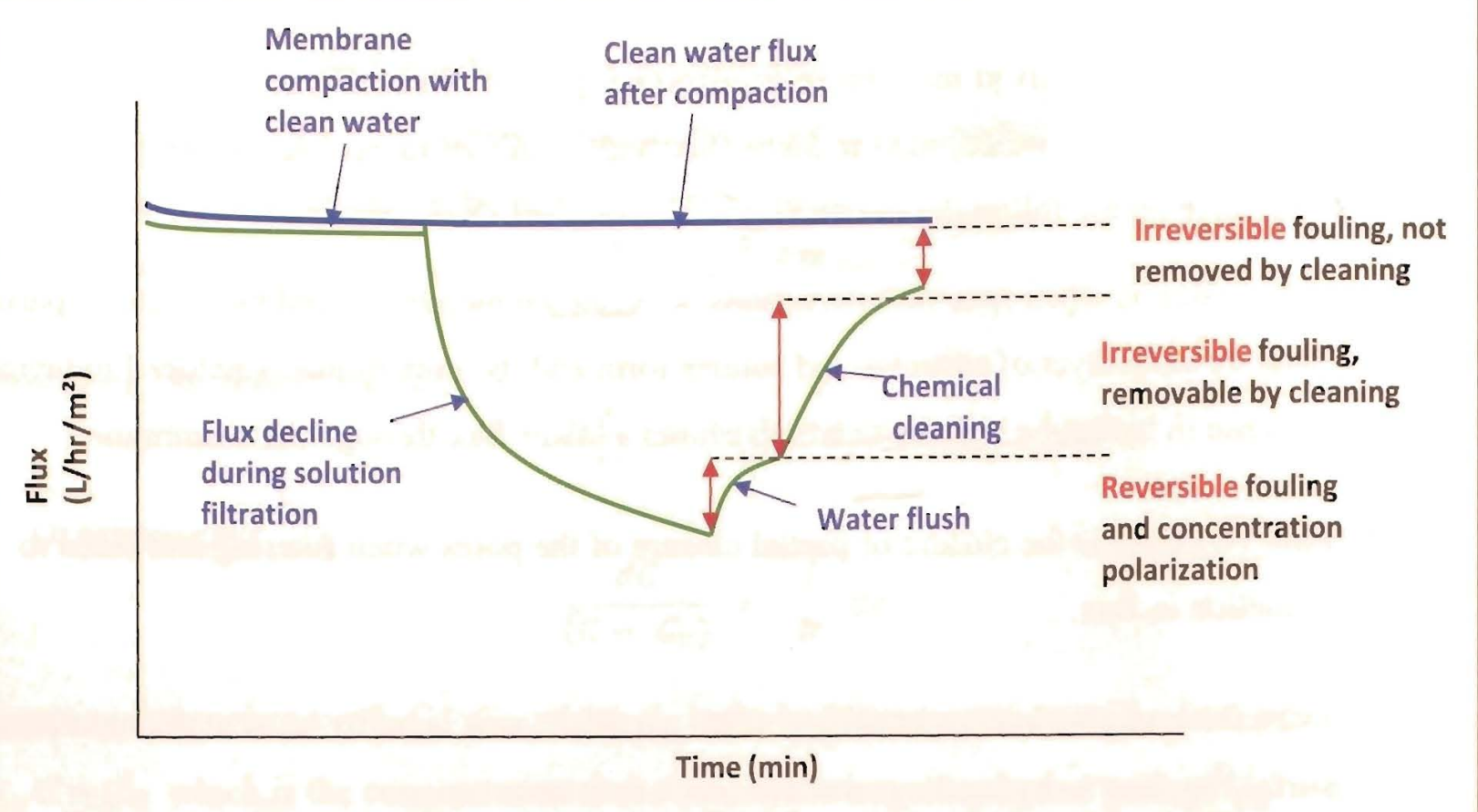

Figure 5.2 Schematic illustration of filtration with concern to membrane fouling (adapted from: Väisänen, 2004)

An alternative to Equation 3.4 is the following Equation 5.5, where $R_{t o t}$ becomes $R_{M}$ the resistance of the membrane, when a fluid fed to the membrane unit fouls the membrane and $R_{c p}$ is the resistance of the concentration polarization layer

$$
J=\frac{\Delta P}{\mu\left(R_{M}+R_{c p}\right)}
$$

Equation 5.5

The equations 5.4 and 5.5 are thermodynamically equivalent (Peinemann, 2010), where the value of $\Delta \pi$ can be calculated through solution of a set of equations, and the value $R_{c p}$ can be deduced from experiments. When the solute is completely rejected by the membrane Equation 5.4 will relate flux and $C_{M}$, provided that $C_{B}$ and $k$ are known. Equation 5.5 will relate flux, $\Delta P$ and $\Delta \pi$, provided that the $R_{M}$ and $\mu$ are known.

To take into account the hydraulic resistance of fouling, additional terms of resistance are added, where the resistance due to fouling $R_{f}$ is

$$
R_{f}=R_{\text {ads }}+R_{\text {rev }}+R_{\text {irrev }}
$$


where $R_{a d s}=$ resistance due to surface or pore adsorption $(1 / \mathrm{m})$

$$
\begin{aligned}
R_{\text {rev }} & =\text { resistance due to reversible fouling }(1 / \mathrm{m}) \\
R_{\text {irrev }} & =\text { resistance due to irreversible fouling }(1 / \mathrm{m})
\end{aligned}
$$

The hydraulic resistance, $R_{a d s}$, occurs in the absence of flux, whereas $R_{r e v}$ (occurs during operation but not present after switching from feed back to pure solvent) and $R_{\text {irrev }}$ (that which is removable at best by a cleaning operation) occur during filtration in the presence of flux (Peinemann, 2010). If we assume that osmotic pressures are negligible, $R_{\text {ads }}$ is negligible and at least one of $R_{\text {rev }}$ or $R_{\text {irrev }}$ is non-zero, then

$$
J=\frac{\Delta P}{\mu\left(R_{M}+R_{f}\right)}
$$

Equation 5.7

At a constant TMP, when the membrane fouls, an increase of $R_{f}$ with time reveals a flux decline. Normally, an initial rapid decrease followed by a longer more gradual decline towards a steady-state value of flux is observed (Song, 1998; Crittenden et al, 2005, Peinemann, 2010).

Table 5.2 General forms of the membrane flux equation (Crittenden et al., 2005)

\begin{tabular}{|c|c|c|}
\hline Flux Equation & Linearized Form & Comments \\
\hline$J_{t}=J_{0} e^{-k t}$ & $\ln \left(\frac{J_{t}}{J_{0}}\right)=-k t$ & $\begin{array}{l}\text { Flux declines exponentially } \\
\text { as foulants accumulate. Flux } \\
\text { assumed to drop to zero at } \\
\text { infinite time, which may not } \\
\text { occur in practice. }\end{array}$ \\
\hline$=J_{s s}+\left(j_{0}-J_{s s}\right) e^{-k t}$ & $\ln \left(\frac{J_{t}-J_{S S}}{J_{0}-J_{S S}}\right)=-k t$ & $\begin{array}{l}\text { Flux drops to a steady-state } \\
\text { flux } J_{S S} \text { at infinite time. }\end{array}$ \\
\hline$J_{t}=J_{0}(k t)^{-n}$ & $\ln \left(\frac{J_{t}}{J_{0}}\right)=-n \ln (k t)$ & $\begin{array}{l}\text { Cannot be used for initial } \\
\text { stages of filtration because } \\
\text { infinite flux is predicted at } \\
\text { time } t=0 \text {. Sometimes } \\
\text { expressed as a function of } \\
\text { the volume of permeate ( } k t \\
=V \text { instead of as a function } \\
\text { of time. }\end{array}$ \\
\hline$J_{t}=\frac{J_{0}}{(1+k t)^{n}}$ & $\ln \left(\frac{J_{t}}{J_{0}}\right)=-n \ln (1+k t)$ & $\begin{array}{l}\text { The series resistance model } \\
\text { can be written in this form } \\
\text { with } n=1 \text {. }\end{array}$ \\
\hline
\end{tabular}
[where, $t$ is time; $J_{t}$ is flux at time; $J_{o}$ is initial flux; $J_{S S}$ is steady-state flux; $k$ and $n$ are parameters that characterize the fouling process] 
General forms for the observed flux decline have been derived to express flux as time-dependent and are expressed in Table 5.2. Experimental data can be fitted to one of the linearized equations in Table 5.2 to obtain the parameters $k$ and $n$, that characterize the fouling process. These forms of membrane flux equation models and the related parameters do not identify the specific fouling mechanisms as shown in Figure 5.3, correlating to the blocking filtration laws: complete pore blocking; internal or standard pore blocking; intermediate or partial pore blocking; and cake filtration.

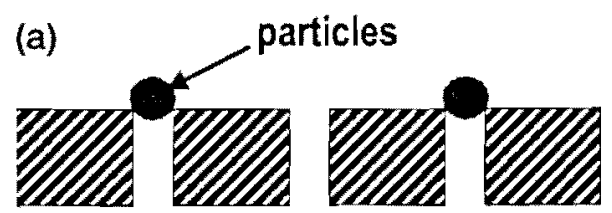

(c)

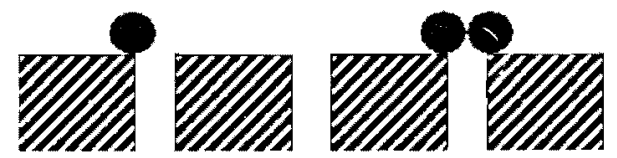

(b)

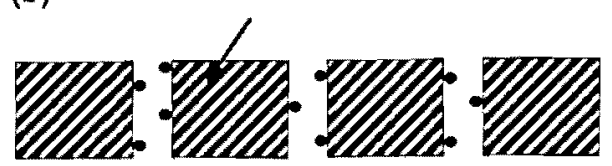

(d)

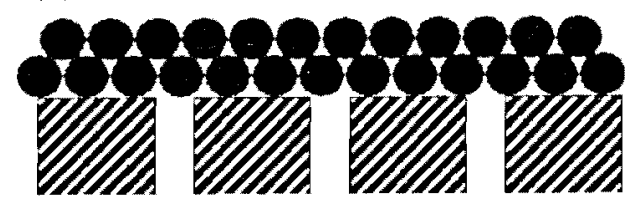

Figure 5.3 Fouling mechanisms of porous membranes, (a) complete pore blocking, (b) internal pore blocking, (c) partial pore blocking and (d) cake filtration (Crittenden et al., 2005)

Further models that simulate fouling mechanisms have been developed under particular laboratory conditions and are collectively known as the blocking laws given in Table 5.3. Specific operating conditions such as filtration under constant-pressure and declining-flux must be applied. In addition, the feed flow direction is directly towards the membrane surface and the particles/solutes approaching the membrane are due to convective forces with no back-migration away from the membrane surface. It is assumed that the membrane surface is flat and uniformly porous, and the particles spherical. These conditions are common in laboratory studies, but not typically the mode used in full-scale operation and industry applications. These expressions when used empirically may not be effective at identifying specific fouling mechanisms. 
Table 5.3 Blocking filtration laws

[where $t$ is time (h); $J_{t}$ is flux at time $t\left(\mathrm{~L} / \mathrm{h} / \mathrm{m}^{2}\right) ; J_{o}$ is initial flux $\left(\mathrm{L} / \mathrm{h} / \mathrm{m}^{2}\right) ; J_{S S}$ is steadystate flux $\left(\mathrm{L} / \mathrm{h} / \mathrm{m}^{2}\right) ; \beta$ and $\varphi$ are parameters that characterize the fouling process (dimensionless); $\rho_{p}$ is the particle density $\left(\mathrm{kg} / \mathrm{m}^{3}\right) ; d_{p}$ is the retained particle diameter $(\mathrm{m})$; $C$ is the particle concentration $(\mathrm{mg} / \mathrm{L}) ; L$ is the membrane thickness $(\mathrm{m}) ; a$ is the membrane area $\left(\mathrm{m}^{2}\right) ; \alpha_{c}$ is the specific cake resistance $(\mathrm{m} / \mathrm{g})$; and $\kappa_{M}$ is the cake layer resistance on the membrane $\left(\mathrm{m}^{-1}\right)$ ] (Crittenden et al., 2005)

\begin{tabular}{|c|c|c|c|}
\hline Flux Equation & $\begin{array}{l}\text { Filtration } \\
\text { Coefficient, }\end{array}$ & $\begin{array}{c}\text { Filtration } \\
\text { Exponent, }\end{array}$ & Major Features and Assumptions \\
\hline \multicolumn{3}{|c|}{ Pore Sealing (Complete Blocking Fittration Law) } & - Models blockage of the entrance to pores by particles \\
\hline \multirow[t]{3}{*}{$J_{1}=J_{0} \mathrm{e}^{-0.5 c h t i o n d}$} & \multirow[t]{3}{*}{$\frac{1.5 \mathrm{CJ}_{0}}{\rho p d_{p}}$} & \multirow[t]{3}{*}{2} & $\begin{array}{l}\text { retained at the membrane surface. } \\
\text { - Each retained particle blocks an area of the membrane } \\
\text { surface equal to the particle's cross-sectional area. }\end{array}$ \\
\hline & & & $\begin{array}{l}\text { - Flux declines in proportion to the membrane area that has } \\
\text { been covered. }\end{array}$ \\
\hline & & & $\begin{array}{l}\text { - No superposition of particles occurs. Each particie lands } \\
\text { on the membrame surface and not on other particles, so } \\
\text { fux reaches zero when a monolayer of particles has been } \\
\text { retained. }\end{array}$ \\
\hline
\end{tabular}

Internal Pore Constriction (Standard Blocking Filtration Law)

$$
f_{1}=\frac{J_{0}}{\left(1+C_{0} t / L_{P P}\right)^{2}} \quad \frac{2 C}{L_{P_{D}}}\left(\frac{J_{0}}{\mathrm{a}}\right)
$$

- Models the reduction of the void volume mithin the membrane.

- Assumes the membrane is composed of cylindrical pores of constant and uniform diameter.

- Particles deposit uniformly on the pore walls; pore volume decreases proportionaly to the volume of particles deposited.

- $L$ - membrane thickness, $m$

\section{Pore Sealing with Superposition (Intermediate Blocking Fitration Law)}

$$
t_{1}=\frac{\rho_{0}}{\left(1+1.5 \mathrm{C} J_{0}\left(p_{p} d_{p}\right)\right.} \quad \frac{1.5 \mathrm{C}}{\rho_{p} d_{p a}}
$$

\section{Cake Fitration Law}

$$
J_{t}=\frac{J_{0}}{\left(1+2 a_{C} \omega_{0}\left(/ x_{\mu}\right)^{0.5}\right.} \quad \frac{a_{C} C}{x_{\mu} J_{0} a^{2}}
$$

- Models blockage of the entrance to pores by particles retained at the membrane surface.

- Extension of the complete blocking fitration law.

- Relaxes the "monolayer" assumption in the complete blocking fitration law by allowing particles to land on previously retained partucles or on the membrane surtace by evaluating the probabilty that a particle wil block a pore.

It was further demonstrated by Hermia (1982) to present a unified power law model Equation 5.8, where the four different flux equations (of Table 5.3) could be written into one consistent characteristic form as (here the $k$ and $n$ parameters are $\beta$ and $\varphi$, respectively) 


$$
\frac{d^{2} t}{d V^{2}}=\beta\left(\frac{d t}{d V}\right)^{\varphi}
$$

where $t=$ time (s)

$V=$ cumulative volume of filtrate (L)

$\beta=$ blocking law filtration coefficient

$\varphi=$ blocking law filtration exponent, unitless

The parameters $\beta$ and $\varphi$ characterize the nature of fouling and are defined for each filtration law in Table 5.4. Using a spreadsheet, the derivatives $d^{2} t / d V^{2}$ and $d t / d V$ can be found and taking the log of the equation gives you the slope as $\varphi$ and a y-intercept as $\beta$. For constant pressure filtration, the Equation 5.8 represents the resistance (inverse flux, $d t / d V$ ) related to the change in resistance $\left(d^{2} t / d V^{2}\right)$ or known as the resistance coefficient (Hermia, 1982).

Table 5.4 Parameters of the blocking filtration laws for constant applied pressure (adapted from: Kumar et al., 2008; Crittenden et al., 2005; Huang et al., 2008; Vela et al., 2008).

\begin{tabular}{|l|c|c|l|}
\hline Model & $\beta$ & $\varphi$ & Comment \\
\hline $\begin{array}{l}\text { Pore Sealing } \\
\text { (Complete Blocking } \\
\text { Filtration Law) }\end{array}$ & $K_{A} V_{O}$ & 2 & $\begin{array}{l}\text { Blockage of individual entrance pores by } \\
\text { particles relained at the membrane surface }\end{array}$ \\
\hline $\begin{array}{l}\text { Internal Pore Constriction } \\
\text { (Standard Blocking Filtration } \\
\text { Law) }\end{array}$ & $\left(\frac{2 K_{B}}{A_{O}^{1 / 2}}\right) V_{0}^{1 / 2}$ & 1.5 & $\begin{array}{l}\text { Retained particles dimensionally smaller } \\
\text { than the average membrane pore size } \\
\text { adhere to the inner pore walls (i.e., } \\
\text { adsorptive fouling or pore narrowing). }\end{array}$ \\
\hline $\begin{array}{l}\text { Pore Sealing with } \\
\text { Superposition (Intermediate } \\
\text { Blocking Filtration Law) }\end{array}$ & $K_{A}$ & 1 & $\begin{array}{l}\text { Blockage of the entrance to the membrane } \\
\text { pores by particles retained at the surface, } \\
\text { particles land on previously retained } \\
\text { particles or membrane surface }\end{array}$ \\
\hline Cake Filtration Law & $R_{r}\left(\frac{K_{C}}{A_{O}^{2}}\right) V_{O}^{-1}$ & 0 & $\begin{array}{l}\text { Particles larger than the average pore size } \\
\text { accumulate on the membrane surface } \\
\text { forming a layer }\end{array}$ \\
\hline
\end{tabular}

where $K_{A}=$ blocked surface area of the membrane per unit of permeate volume $\left(\mathrm{m}^{-1}\right)$,

$K_{B}=$ decrease in the cross-section area of the pores per unit of permeate volume $\left(\mathrm{m}^{-1}\right)$, $K_{C}=$ area of cake per unit volume $\left(\mathrm{m}^{-1}\right)$, $A_{O}=$ area of clean membrane $\left(\mathrm{m}^{2}\right)$, $R_{r}=$ ratio of cake resistance over the clean membrane resistance (dimensionless) and $V_{O}=$ initial mean velocity of the fluid through the membrane $(\mathrm{m} / \mathrm{s})$. 
Equation 5.8 is the time of filtration differentiated with respect to the volume of filtrate collected per unit area. The flux $J$ and flux decline can also be taken into account and the model written as (Peinemann, 2010)

$$
\frac{d J}{d t}=-\beta J^{3-\varphi}
$$

An approach with the allowance for cross flow was developed where Equation 5.9 is modified and becomes (Peinemann, 2010)

$$
\frac{d J}{d t}=-\beta\left(J-J_{S s}\right)^{2-\varphi}
$$

where $J_{S S}$ is the steady-state flux reached at extended times. Additional study of this model is described in Field et al., 1995.

Further model developments of filtration and fouling conditions under constant flux and models valid for both constant pressure and constant flux have been developed (Huang et al., 2008, Peinemann, 2010), but not presented here. In this work the Hermia model is applied to the experimental data obtained with graphical examples shown in the results and discussion section.

Membrane fouling occurs due to physiochemical and biological mechanisms, related to increased deposition of solid material onto the membrane surface (binding) and within the membrane structure (pore restriction, or pore plugging). Clogging, is the filling of membrane channels with solids due to poor hydrodynamic performance. That is, the motion of the fluid through the channel flow path, and the forces exerted in a sintered membrane pore channel. It was observed, however, that with membranes having higher pore ratios (where pore ratio is the pore surface length per pore surface width) features, such as elliptical and less circular, were found to exhibit reduced fouling (Judd, 2006). A study done by Park et al., 2005 also found that with higher recirculation rates, tested in their MBR coupled with HCR (High performance Compact Reactor) resulted in higher turbulence and thus alleviated membrane fouling. However, when the recirculation rate was too high, the microbial solids were broken down by fluid shear clogging the pores and rapidly decreasing membrane permeability. 


\section{Membrane and Foulant Interactions}

Membranes may be damaged by the presence of chemical substances that react with the membrane. Typical constituents in wastewater that cause fouling of membranes are shown in the Table 5.4. The interaction between foulant and the membrane is more pronounced for the colloidal and macromolecular organic matter than for particulates, due to the fact that they are smaller in size. Many factors influence the interaction, such as charge, $\mathrm{pH}$, hydrophobicity, multivalent ions $\left(\mathrm{Ca}^{2+}\right.$ and $\mathrm{Mg}^{2+}$ ), ionic strength, membrane morphology, etc. These interactions can significantly influence membrane fouling and permeate quality.

Table 5.5 Typical types of fouling and the constituents in wastewater that cause fouling and other constituents that can cause damage to membranes

[note: In many cases, multiple types of fouling can occur simultaneously]

(Adapted from: Asano et al., 2007; U.S. EPA, 2005).

\begin{tabular}{|c|c|c|c|c|}
\hline & Particulate & Organic & Biofilm & Scaling \\
\hline Foulants & $\begin{array}{l}\text { Colloids, Suspended } \\
\text { solids }\end{array}$ & Organic matier & Microorganism & $\begin{array}{l}\text { Salt Metal Cations } \\
\text { (precipitation of } \\
\text { supersaturated salts) }\end{array}$ \\
\hline $\begin{array}{l}\text { Examples of } \\
\text { Constituents }\end{array}$ & $\begin{array}{l}\text { Organic /inorganic } \\
\text { colloids, Clays and silts, } \\
\text { silica, Iron and } \\
\text { manganese oxides, } \\
\text { Oxidized metals, Motal } \\
\text { salt coagulant products }\end{array}$ & $\begin{array}{l}\text { Natural organic matter } \\
\text { (NOM) including humic } \\
\text { and fulvic acids, proteins, } \\
\text { and polysaccharides, } \\
\text { Polymers used in } \\
\text { treatment process }\end{array}$ & $\begin{array}{l}\text { Dead and living } \\
\text { microorganisms, } \\
\text { Polymers produced } \\
\text { by microorganisms }\end{array}$ & $\begin{array}{l}\text { Calcium Carbonate, } \\
\text { Calcium Flouride, Calcium } \\
\text { phosphate, Barium sulfate, } \\
\text { Strontium sulfate, Silica }\end{array}$ \\
\hline $\begin{array}{l}\text { Cause } \\
\text { factors }\end{array}$ & $\begin{array}{l}\text { Concentration } \\
\text { polarization/Gel } \\
\text { formation }\end{array}$ & $\begin{array}{l}\text { Concentration } \\
\text { polarization (cake } \\
\text { formation), Gel formation }\end{array}$ & $\begin{array}{l}\text { Concentration } \\
\text { polarization/Gel } \\
\text { formation }\end{array}$ & $\begin{array}{l}\text { Precipitation, } \\
\text { Concentration } \\
\text { polarization/Gel formation }\end{array}$ \\
\hline $\begin{array}{l}\text { Major factors } \\
\text { affecting } \\
\text { fouling }\end{array}$ & $\begin{array}{l}\text { Concentration, Particle } \\
\text { size distribution, } \\
\text { Compressibility of } \\
\text { particles }\end{array}$ & $\begin{array}{l}\text { Concentration, Charge, } \\
\text { Hydrophobicity, } \mathrm{pH} \text {, lonic } \\
\text { strength }\end{array}$ & $\begin{array}{l}\text { Temperature, } \\
\text { Nutrients }\end{array}$ & $\begin{array}{l}\text { Temperature, } \\
\text { Concentration, } \mathrm{pH}\end{array}$ \\
\hline $\begin{array}{l}\text { Feed water } \\
\text { pretreatment }\end{array}$ & Coagulation, MF / UF & $\begin{array}{l}\text { Adjustment of } \mathrm{pH}_{\mathrm{s}} \\
\text { Coagulation }\end{array}$ & $\begin{array}{l}\text { Sand filtration, } \\
\text { Biofilter, Coagulation, } \\
\text { Flocculation, MF / UF }\end{array}$ & Acid, Anti-scalant \\
\hline Remarks & $\begin{array}{l}\text { Particulate fouling can } \\
\text { be reduced by cleaning } \\
\text { the membrane at } \\
\text { regular intervals }\end{array}$ & $\begin{array}{l}\text { Effective pretreatment } \\
\text { can be used to limit } \\
\text { organic fouling }\end{array}$ & $\begin{array}{l}\text { Biofilms are formed } \\
\text { on the membrane } \\
\text { surface by colonizing } \\
\text { bacteria }\end{array}$ & $\begin{array}{l}\text { Scaling can be reduced by } \\
\text { limiting salt content, by pH } \\
\text { adjustment, and by other } \\
\text { chemical treatments (e.g., } \\
\text { antiscalants) }\end{array}$ \\
\hline
\end{tabular}


When solutes such as colloids or macroorganics, and a stationary membrane surface have the same charge, the solute is repelled by the membrane due to electrostatic forces. As a result, the adsorption of colloids or macroorganics is less. Many colloids and macroorganics are negatively charged at neutral $\mathrm{pH}$ conditions, hence, the membranes used in water and wastewater filtration processes are often manufactured or modified to be negatively charged.

The charge of colloids and macroorganics are influenced by $\mathrm{pH}$. At a high $\mathrm{pH}$, dissociation of protons from colloids or macroorganics results in more negatively charged substances. However, it is not feasible to adjust the $\mathrm{pH}$ for fouling purposes alone when the filtration of water and wastewater are performed at neutral $\mathrm{pH}$ conditions. Most membranes are made to be hydrophilic, so that they have the advantage of high membrane permeability and a low attraction to foulants such as natural organic matter, NOM. In a review of chemical cleaning of membranes by Porcelli et al., (2010), it was stated that the foulant and membrane interact mainly through hydrophobic attraction and that the mechanism for cleaning is primarily electrostatic repulsion. 


\subsection{Membrane Cleaning Methods and Example Applications}

A number of approaches are available to reduce membrane fouling and are discussed in the following sections.

\section{Conventional Membrane Cleaning}

It is necessary to protect the membrane from damage or eventual clogging of the pore, therefore the requirements of pretreatment processes are applied. Pretreatment processes are an integral part of membrane filtration facilities; they include prefiltration, flushing and cleaning abilities. Rejected constituents in the retentate stream tend to accumulate at the membrane surface, producing the fouling phenomena. Here is a general list of some prevention or controlling of membrane fouling put in practice:

1. Apply appropriate pretreatment to the feed water (e.g. classical coarse screen in primary treatment of $6 \mathrm{~mm}$ is insufficient before MBRs, where the optimum is $0.8-1.5 \mathrm{~mm}$ or $2-3 \mathrm{~mm}$ for flat sheet membranes). In some cases, replacement of polymeric membranes with ceramic membranes has eliminated preliminary cleaning of wastewaters.

2. Employing appropriate physical cleaning protocols, such as relaxation, backwash or backpulse depending on the membrane module and process configuration (e.g. for tubular membranes, duration and frequency of backflushing, flux, relaxation, causes process downtime, although cleaning methods are usually recommended by the supplier)

3. Employing appropriate chemical cleaning protocols, such as chemically enhanced backwashing or membrane soaking (overall, chemical solutions have a concentrations that is at most $10 \%$ by weight. Reduction in the amount of chemical usage is encouraged)

4. Reducing the flux (which unfortunately directly impacts capital costs, through membrane area demand)

5. Increasing the aeration or use of membrane air scour devices (usually in submerged membrane units resulting in increased expenses)

6. Chemically and biochemically modifying the mixed liquor feed solution.

7. Applying sonophysical cleaning aids

All these approaches to fouling and clogging control are viable options and are applied for full-scale operating membrane technologies. 
Before wastewater that is to be treated reaches the membrane filtration unit, microscreening or prefiltration to remove coarse sediments/grit can be required. Prefiltration mechanism is primarily straining which is done by self-cleaning screens, cartridge filters or bag filters.

Flushing of the membranes can be either in the forward direction same as the filtration or is done in the reverse direction of the filtration flow known as backwash/backpulse. In either case, flushing assists in the removal of the surface cake. Forward flushing incorporates high-velocity flows to reduce cake build-up on the surface of the membranes.

For backwashing the goal is to flush trapped particles from the membrane pores and cavities that develop during the cycle of filtration. Implementation of backwashing is performed in a timed interval of a filtration cycle that ranges from 30-90 minutes and lasts for 1-30 minutes, depending on the manufacturer. Backwashing can be initiated earlier if increase in transmembrane pressure during the filtration exceeds preset limits. The backwashing of membranes involve using either air or liquid water (or permeate water) that is then wasted (Potyomkina et al.2000, Degueldre et al., 1999). It is desirable to waste small volumes of the backwash water produced. This ensures the efficiency or recovery of the backwash cleaning methods. If the wasted wash-water is recovered and treated back to the filtration feed stream, high recoveries of backwashing can be maintained. The pressure applied for the backwash can be either higher or lower than the pressure used during the normal filtration cycle. When backwashing is applied more frequently on a timely basis, this results in conserving energy which is obviously most favourable. Chemical solutions are also employed with backflushing, that is, instead of using water for the wash liquid, a chemical solution with concentrations typically less than $5 \%$ weight can be used during backwash. This is known as chemically enhanced backwash/backflush, CEB.

Chemical cleaning can be a fully manual procedure, a semi-automated approach, or a fully automated approach. Membrane cleaning using chemicals can be classified into either maintenance cleaning or recovery cleaning. Maintenance cleaning increases the time between recovery cleanings and is often as once per day to once per week and is fewer than 2 hours in duration (WEF, 2006). Maintenance cleaning use lower concentrations of chemicals than the recovery cleaning which is typically done once every 2 to 6 months with a duration of 6 to 24 hours. The need for aggressive cleaning agents, however, shortens the membrane life. For chemical cleaning of fouled membranes, 
five categories of cleaning agents are commonly used:

$>$ alkaline

$>$ acids

$>$ metal chelating agents

$>$ surfactants

$>$ enzymes

Generally, the cleaning agent cleans the membrane by: removing the foulants, changing the morphology of the foulants, or altering the surface chemistry of the fouling layer (Porcelli et al., 2010).

An alkaline solution of sodium hydroxide, $\mathrm{NaOH}$ (or caustic soda) has the ability to solubilize proteins to some extent and forms part of most commercial alkaline cleaners. Hydroxide encourages dissolution of weakly acidic organic matter and may also be effective for removing inorganic colloids (Porcelli et al., 2010). A study by Blanpain-Avet et al., 2009, selected sodium hydroxide at a $1 \mathrm{wt} \%$ concentration on the basis of the standard cleaning procedure recommended by the manufacturer for the recovery of the permeability of MF/UF Kerasep membranes fouled with food fluids. They concluded that an optimum cleaning time of 20 minutes was effective for chemical cleanliness, but the percent flux recovery was insufficient. Other investigations have found or demonstrated the efficiency of sodium hydroxide in removing proteins or organic substance deposits formed on filtration membranes (Al-Amoudi et al., 2007; Blanpain-Avet et al., 2009; Zhang et al., 2009).

Another chemical cleaning reagent such as hydrochloric acid, $\mathrm{HCl}$, is used in wastewater treatment plants (WEF, 2006) for their low cost (Porcelli et al., 2010) and is effective for CEB. A study by Zhong et al., 2006, incorporated cleaning of fouled membranes by comparing water flux before cleaning and after cleaning. The cleaning solutions entailed hydrochloric acid and hydrochloric acid mixed with various physical cleaning methods including ultrasound. They were able to achieve a flux recovery of $52 \%$ using cleaning solution concentration of about $0.5 \%$ and $84 \%$ recovery with combined acid cleaning and physical cleaning by ultrasound. Other studies using acetic acid (Nicolaisen, 2001) may also be employed as cleaning chemicals. Acid cleaning aims to remove multivalent cationic species such as hardness salts and metal hydroxides. 


\section{Alternative Membrane Cleaning}

The obvious problem of fouling in membrane filtration has gained much attention. A report by Kyllönen et al., 2005 reveals the following:

$>$ the level of membrane fouling is dependent on the feed suspension properties

(particle size, particle concentration, $\mathrm{pH}$, ionic strength),

membrane properties (hydrophobicity, charge, pore size), and

hydrodynamics (cross-flow velocity, transmembrane pressure).

Studies have been done with ultrasonically induced effects which were applied to membrane processes to aid in the cleaning and to produce enhanced separation filtration, see Figure 5.3 permeate flux of the membrane versus with and without ultrasound.

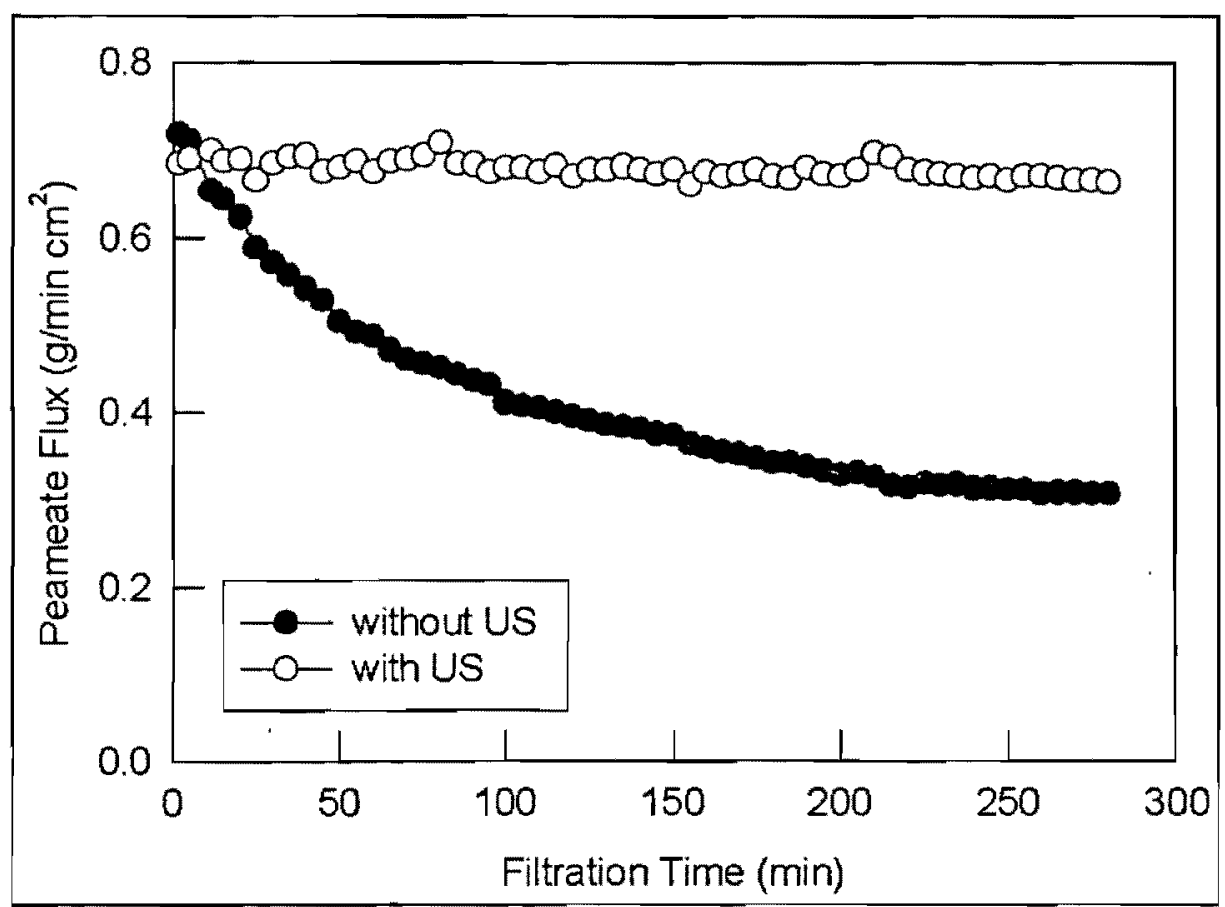

Figure 5.4 Permeate flux of the membrane with or without ultrasound. (Particle concentration was $0.1 \mathrm{~g} / \mathrm{L}$. Particle size was 1.56 $\mu \mathrm{m}$. Distance between the membrane surface and the ultrasonic probe is $3.5 \mathrm{~cm}$. The crossflow rate was 500 $\mathrm{mL} / \mathrm{min}$.) (source: Chen, 2005).

High intensity of ultrasonic waves through a liquid is done by primary phenomena's such as cavitation or acoustics. Collapse of the cavitation bubbles near the surface of a membrane produces 
a nonsymmetrical rush of fluid to fill voids, with a result of a liquid jet at high speed. The liquid jet is used as a basis for the cleaning, but there are other cavitation problems such as microstreaming and microstreamers, that also lead to particle release from a fouled surface. Acoustical streaming can play a role in the transport of particles away from the membrane.

Cavitation occurs at frequencies of roughly $20-1000 \mathrm{kHz}$ and the implosions occur with lifetimes of less than $10 \mu \mathrm{s}$. For membrane filtration experiments, frequencies ranging from $18 \mathrm{kHz}$ up to $1 \mathrm{MHz}$ have been used. Higher frequencies result in more cavitation bubbles collapsing with time, therefore enhancing ultrasound effects on membrane fouling. However, higher frequencies means the collapsing bubbles are smaller in size and collapse less energetically. At very high frequency the rarefaction (and compression) cycles are too short to permit a bubble to grow to a size sufficient to cause disruption of the liquid. Even if a bubble is to be produced during rarefaction, the time required to collapse that bubble may be longer than the time available in the compression halfcycles. The resultant cavitiational effects will, therefore, be less at the higher frequencies (Kyllonen, 2005; Mason and Lorimer, 1988). Therefore higher frequencies may not necessarily be capable of detaching particles from the cake layer as readily as bubbles formed at lower frequencies.

Table 5.6 Factors influencing the effectiveness of ultrasound (source: Kyllonen, 2005)

\begin{tabular}{|c|c|}
\hline \multirow{4}{*}{$\begin{array}{c}\text { Factors } \\
\text { influencing } \\
\text { ultrasound } \\
\text { effectiveness }\end{array}$} & Frequency \\
\cline { 2 - 2 } & Power intensity \\
\cline { 2 - 2 } & Irradiation time \\
\cline { 2 - 2 } & Meed properties \\
\cline { 2 - 2 } & Cross-flow velocity \\
\cline { 2 - 2 } & Temperature \\
\cline { 2 - 2 } & Pressure \\
\hline
\end{tabular}

Ultrasonic cleaning is effective on sound-reflecting materials. Alumina is a good sound-reflecting material that offers the potential for facile cleaning by ultrasound. Ultrasound cannot keep the particles totally away from the membrane, but can clean it and help facilitate the filtration process. The membrane properties such as pore size, pore geometries, porosity and hydrophilicity are some important factors to consider when incorporating the use of ultrasound. 
Ultrasound is most commonly produced by electromechanical transducers, which are based on the piezoelectric effect. In membrane filtration the transducers are either integrated to the membrane module or the ultrasonic bath. An ultrasonic water bath, which the membrane module is immersed in, is only useful in laboratory studies because of a high waste of acoustic energy (Kim et al., 2002; $\mathrm{Li}$ et al., 2002; and Juang et al., 2004). A transducer integrated membrane module is more successfully tested in a microfiltration apparatus in industrial pilot-scale runs. Ultrasound irradiation does not influence the permeability of the membranes, but increases the flux by preventing fouling of membranes. Ultrasound can break the cake layer at the membrane surface and decrease the solute concentration near the membrane. Several factors influence the effectiveness of ultrasound irradiation in fouling prevention and are listed in Table 5.5. Kyllönen et al. further goes on to state that in general:

$>$ Lower ultrasound frequencies have higher cleaning efficiencies than higher frequencies.

$>$ An increase in power intensity provides an increase in sonochemical effects, that is, in sonic waves and wave properties when applied to chemical reactions and processes.

$>$ A high flux enhancement can be obtained with an intermittent ultrasonic field.

$>$ The particle size of the feed and its proportion to the pore size of the membrane affect the flux.

$>$ Ultrasound is less effective for a very concentrated or viscous feed than for lower concentrations or viscosities.

$>$ In ultrasound-aided filtration the flux can be high regardless of the cross-flow velocity. The membrane filtration coupled with ultrasound have been tested in both the crossflow (Kin et al, 2002; Li et al, 2002; and Juand et al 2004) and the dead end (Masselin et al., 2001) modes by various researchers. Garmash et al., 1995, states that tangential filtration makes it possible to substantially increase the service life of a filtering element as compared with frontal filtration, ensuring easier regeneration, stabilization of productivity in the installation with respect to time, and eliminates the formation of precipitate on the working surface of the elements.

Power range of 60 to $150 \mathrm{~W}$ was found suitable by Shu et al., 2007, for membrane fouling control. The membrane fouling was very well controlled for over a week with a crossflow velocity of 0.75 $\mathrm{m} / \mathrm{s}$, equaling the effect of crossflow velocities of more than $1.0 \mathrm{~m} / \mathrm{s}$ without ultrasound. From Kyllönen et al., 2005, states that ultrasonic power intensity used in cleaning varies between 0.5 and 
$6 \mathrm{~W} / \mathrm{cm}^{2}$. Also, irradiation of ultrasound may be perpendicular from the permeate side or the feed flow side of the membrane, or the membrane may be placed vertically against the transducer. For ultrafiltration, the highest flux has been achieved when the ultrasound irradiation (at $40 \mathrm{kHz}$ ) direction is from the feed side of the membrane and lowest flux when irradiated from the permeate side of the membrane. On the other hand, for microfiltration ultrasound propagation from the feed side resulted in fouling of the membrane and a decrease in flux to the level as without ultrasound, but the highest flux was obtained when irradiated from the permeate side. Kyllönen et al., 2005, study showed that the more open the membrane the easier the membrane is fouled when the ultrasound propagates from the feed flow side of the membrane. If the membrane is tight enough, ultrasound irradiated from the feed side of the membrane increases the flux significantly.

Shu et al. (2007), showed the enhancement of crossflow filtration and cleaning of $\mathrm{ZrO}_{2}$ ceramic tubular membranes under an ultrasonic field in treating emulsification wastewater. A systematic investigation on the influence of certain parameters, such as the ultrasonic power and propagating direction was performed, resulting to discover that the highest cleaning efficiency and shorter cleaning time was best achieved in a combination of chemical agents with ultrasonic irradiation. 


\subsection{EXPERIMENTAL MATERIALS AND METHODS}

\subsection{Materials}

\subsubsection{Experimental Apparatus}

The ceramic membrane filtration unit has been built in the Laboratory of Water and Wastewater of the Department of Chemical Engineering. The laboratory also consists of other reactors including an aerobic and an anaerobic fluidized bed reactor, a Rotating Biological Contactor and a Compact Upright Bioreactor for the Elimination of Nutrient (CUBEN). The ceramic membrane unit can be operated to treat the effluent from CUBEN which has connected pipelines to the membrane unit, as well as other individual fluids by using the feed container. The laboratory is equipped with chemical sensors, analyzers and data acquisition system. In this study the membrane apparatus is designed and used to treat various fluids that are specified later in Sections 6.1.3 and 6.1.4. Description of the process is given next and corresponds to the flow diagram shown in Figure 6.1.

The process starts with (1) a 65 litre feed container where the fluid solution to be filtered is added. At the bottom of the feed container the fluid exits through PVC piping to (2) the feed pump. Fluid is introduced to the membrane unit through stainless steel piping by the feed pump at a flow rate of approximately 36 to $80 \mathrm{~L} /$ day and pressures of approximately 0.5 to 3 atmospheres. The stainless steel piping splits into two streams to distribute the fluid to the membranes in parallel (3) and (4). Flow meters (F) and pressure sensors (P) are set-up before the membrane unit to regulate operating conditions. Each membrane produces a permeate (or filtrate) and retentate (or concentrate) stream which is collected in containers $(5,7)$ and $(6,8)$, respectively.

The apparatus can work in both dead-end and cross-flow configurations by closing or adjusting the retentate valves ( $\mathbf{V}-5$ and $\mathbf{V}-7$ ). However, in this research, crossflow mode is performed. Fluid enters the top of the membrane housing which cases the membranes, see Section 6.1.2 for further details. Both permeate and retentate outlet ports are open to the atmosphere. Clean water filtration at a minimum flux of about $152 \mathrm{~L} / \mathrm{hr} \cdot \mathrm{m}^{2}$ per atm and a maximum of $203 \mathrm{~L} / \mathrm{hr} \cdot \mathrm{m}^{2}$ per atm (or 150 to 200 $\mathrm{L} / \mathrm{hr} \cdot \mathrm{m}^{2}$ per bar) is reported by the manufacturer. 


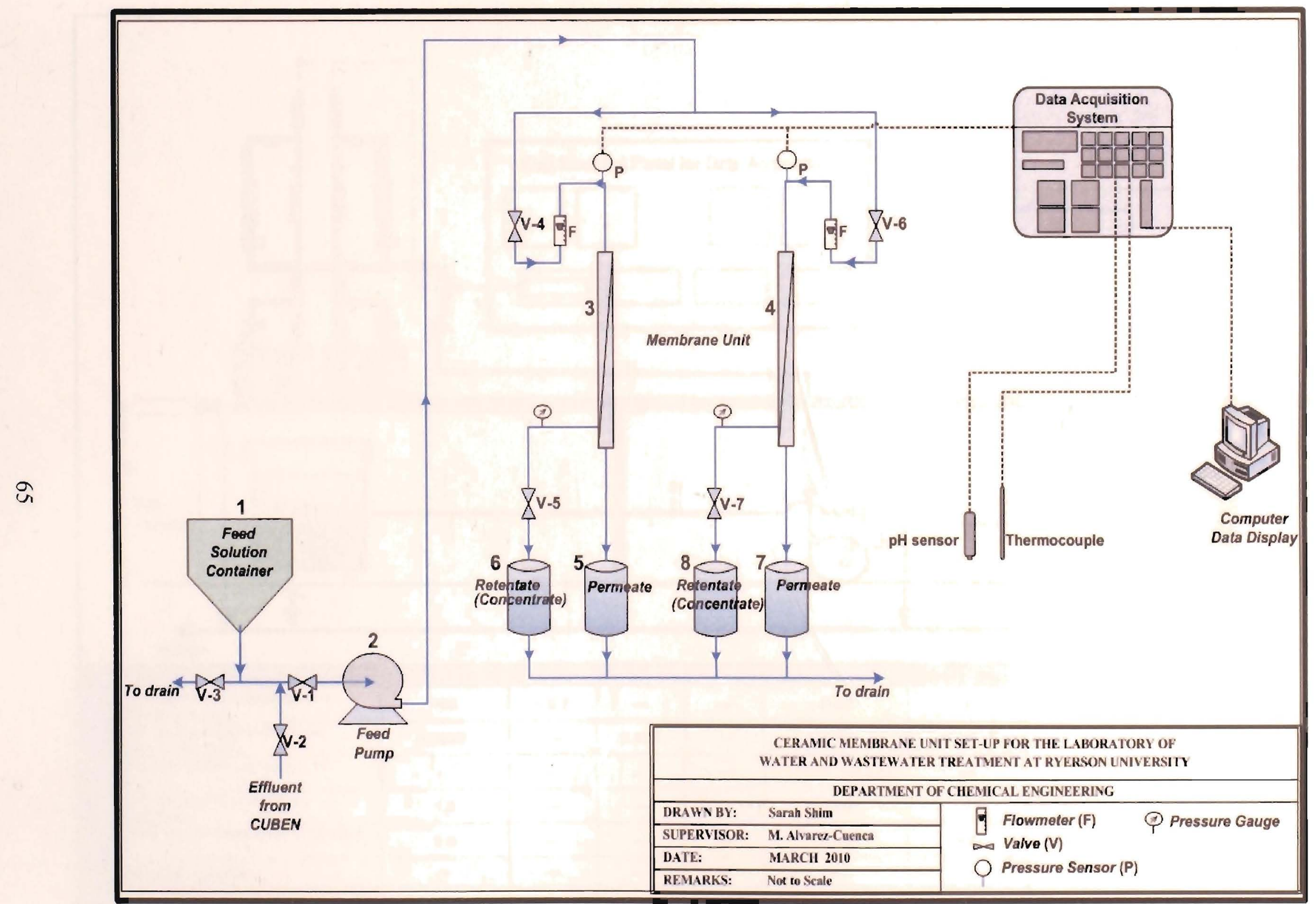

Figure 6.1 Diagram of the Ceramic Membrane Filtration Apparatus. The equipment/materials used to build the apparatus are tabulated in Table 6.1 


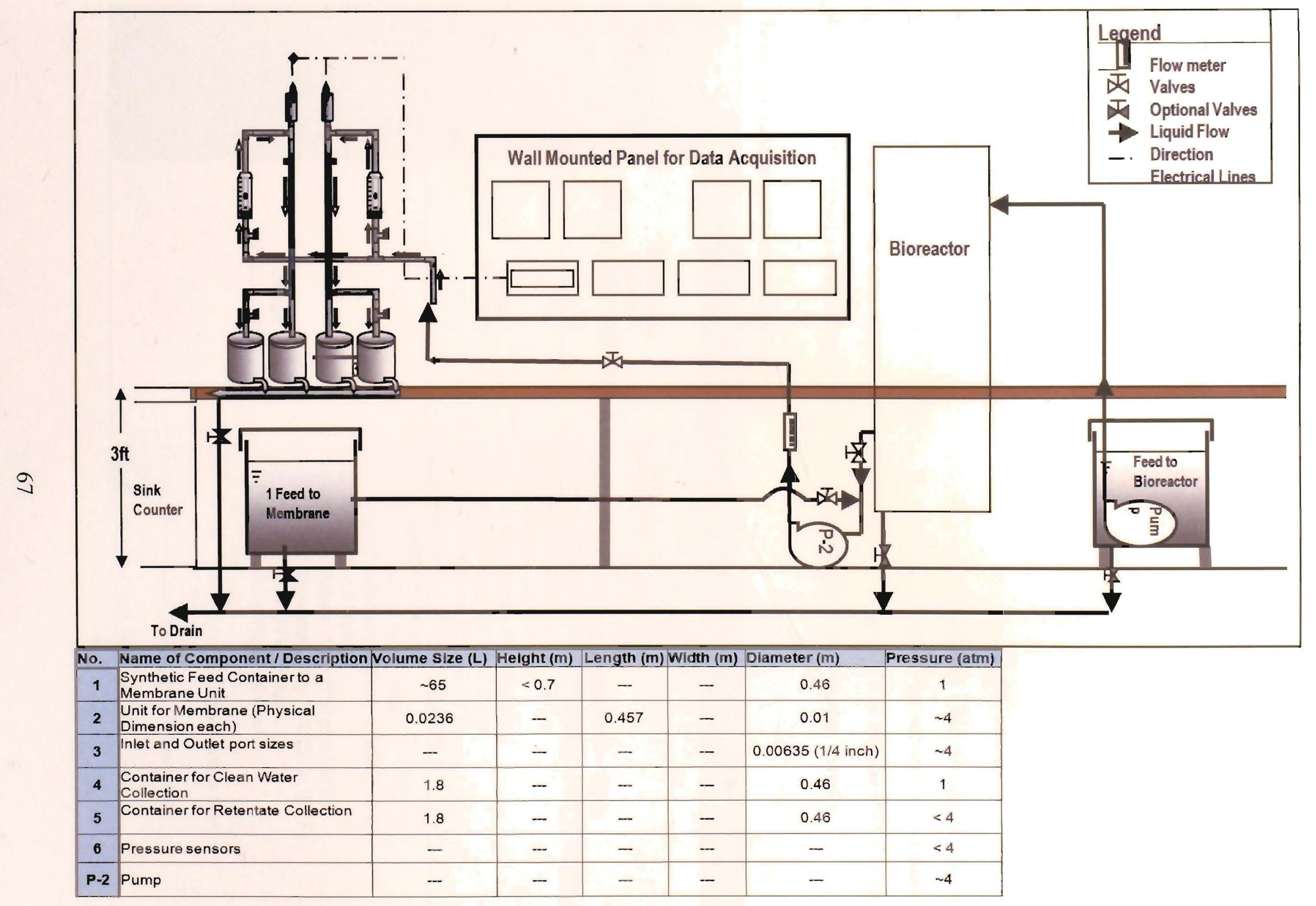

Figure 6.2 Set-up of the Ceramic Membrane Unit and CUBEN bioreactor in the Wastewater Laboratory 
The selection of the pump is based on various factors such as the type of feed, adjustable flow rates, pressure necessary for flow through the membrane and consistency of pumping dosage. Based on the manufacturers' permeability, and the desire to treat approximately $120 \mathrm{~L} /$ day of various fluids, the choice to use the metering pump from ProMinent is appropriate. The flow meters used are rotameters from Omega that features a dial for adjustable flow rate and control with flow rate reading range from 1.5 up to $13.5 \mathrm{~L} / \mathrm{hr}$. The $\mathrm{pH}$, temperature and pressure sensors were also purchased from Omega and are connected to the available data acquisition system with computer output. Snubbers for the pressure sensors were installed to protect the pressure sensors from damage. Pressure gauges, located on the retentate exit stream, are to verify the TMP along the feed side of the membrane. Figure 6.3 is a photograph of the built apparatus. The sensors connected to the apparatus are linked to the data acquisition system which sends data to a computer (not shown in the photo) where its logged using software program and outputted on the display monitor.

Table 6.1 Equipment used and description

\begin{tabular}{|c|c|c|}
\hline Equipment & Company Brand (Model) & Description \\
\hline $\begin{array}{l}\text { Solenoid Driven } \\
\text { metering Pumps }\end{array}$ & $\begin{array}{c}\text { ProMinent } \\
\text { (gamma/ } \\
\text { GALA0413PCE260UD112000) }\end{array}$ & 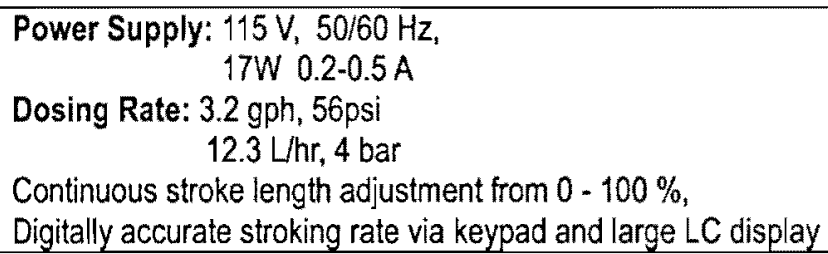 \\
\hline Rotameter & $\begin{array}{l}\text { Omega } \\
\text { (FL-2047) }\end{array}$ & $\begin{array}{l}\text { Water Range Scale: } 1.5 \text { to } 13.5 \mathrm{~L} / \mathrm{hr} \\
\text { Float: Black glass stainless steel } \\
\text { Body: Durable one-piece clear acrylic } \\
\text { Seals: Buna "O" Rings with brass fittings } \\
\text { Pressure: } 100 \text { psig max @ } 21^{\circ} \mathrm{C}\left(70^{\circ} \mathrm{F}\right) \\
\text { Temperature: } 65^{\circ} \mathrm{C}\left(150^{\circ} \mathrm{F}\right) \max @ 0 \text { psig }\end{array}$ \\
\hline Pressure Sensor & $\begin{array}{c}\text { Omega } \\
\text { (PX302-050GV) }\end{array}$ & $\begin{array}{l}\text { Pressure range: } 0 \text { to } 3.4 \text { atm } \\
\text { Excitation: } 10 \text { Vdc ( } 5 \text { to } 15 \mathrm{Vdc} \text { limits) } \\
\text { Output: } 10 \mathrm{mVN} \text { ratiometric, } 100 \mathrm{mV} \pm 1 \mathrm{mV} @ 10 \mathrm{Vdc} \\
\text { Accuracy: } 0.25 \% \text { Full Scale } \\
\text { Operating Temperature: }-18 \text { to } 71^{\circ} \mathrm{C}\left(0 \text { to } 160^{\circ} \mathrm{F}\right) \\
\text { Compensated Temperature: }-1 \text { to } 71^{\circ} \mathrm{C}\left(30 \text { to } 160^{\circ} \mathrm{F}\right) \\
\text { Total Thermal Effects: } \pm 1 \% \mathrm{FS} \text { max } \\
\text { Proof Pressure: } 200 \%, 13,000 \mathrm{psi} \text { max } \\
\text { Response Time: } 1 \mathrm{~ms} \\
\text { Wetted Parts: } 17-4 \mathrm{PH} \text { and } 300 \text { Series stainless steel } \\
\text { Pressure Port: } V 4 \mathrm{NPT} \text { male } \\
\text { Electrical Connection: PX302: } 1 \mathrm{~m}\left(3^{\prime}\right) \text { 4-conductor } \\
\text { unshielded cable } \\
\text { Weight: } 131 \mathrm{~g}(4.6 \mathrm{oz}) \text { to } 1000 \mathrm{psi}\end{array}$ \\
\hline
\end{tabular}


Continued from Table 6.1

\begin{tabular}{|c|c|c|}
\hline Equipment & Company Brand (Model) & Description \\
\hline Thermocouple & $\begin{array}{c}\text { Omega } \\
\text { (TJ36-CPSS-116U-6) }\end{array}$ & $\begin{array}{l}\text { Material: } 304 \text { SS and incone } 600 \\
\text { Lead length with stripped leads: } 1 \mathrm{~m}\left(40^{\prime \prime}\right) \\
\text { Manufactured with compacted mineral insulation cable for long-lasting } \\
\text { performance in harsh conditions } \\
\text { Use of fiberglass and ceramic insulation allows the transition joint to be } \\
\text { used up to } 482^{\circ} \mathrm{C}\left(900^{\circ} \mathrm{F}\right)\end{array}$ \\
\hline $\begin{array}{l}\text { Submersible pH } \\
\text { Sensor }\end{array}$ & $\begin{array}{c}\text { Omega } \\
\text { (PHE-7352-15) }\end{array}$ & $\begin{array}{l}\mathrm{pH} \text { Range: } 0 \text { to } 14 \mathrm{pH} \\
\text { Temperature Range: } 0 \text { to } 80^{\circ} \mathrm{C} \\
\text { Pressure Range: } 0 \text { to } 7 \mathrm{~atm} \\
\text { Sodium Error: }<0.05 \mathrm{pH} \text { in } 0.1 \mathrm{Molar} \mathrm{Na}+\text { ion @ } 12.8 \mathrm{pH} \\
\text { Impedance: } 150 \mathrm{M} \Omega @ 25^{\circ} \mathrm{C}\left(77^{\circ} \mathrm{F}\right) \\
\text { Reference Cell: Double junction KNO3 and KCl/AgCl} \\
\text { Zero Potential: } 7.0 \mathrm{pH} \pm 0.2 \mathrm{pH} \\
\text { Wetted Materials: Ryton@, PTFE, FKM, glass } \\
\text { Response Time: } 95 \% \text { of reading in } 10 \mathrm{seC} \\
\text { Drift: }<2 \mathrm{mV} \text { per week }\end{array}$ \\
\hline Pressure Gauge & $\begin{array}{c}\text { Omega } \\
\text { (PGUF-25B-60PSI/4BAR) }\end{array}$ & $\begin{array}{l}\text { Ranges: from } 0 \text { to } 4 \text { atm } \\
\text { Accuracy: } \pm 2.5 \% \\
\text { Bourdon Tube: Phosphor bronze } \\
\text { Window: Polycarbonate } \\
\text { Dial: Galvalume white background with blue/black markings } \\
\text { Pointer: Galvalume black finish } \\
\text { Movement: Brass } \\
\text { Case and Ring: } 304 \text { SS } \\
\text { Connection: } 144 \text { MNPT [18 MNPT on } 38 \mathrm{~mm}\left(112^{n}\right) \text { dials] } \\
\text { Seals: Buna-N } \\
\text { Scale: Dual scale psibar }\end{array}$ \\
\hline Snubbers & $\begin{array}{l}\text { Omsga } \\
\text { (PS-4E) }\end{array}$ & $\begin{array}{l}\text { Pressure ratings up to } 680 \text { atm } \\
\text { Made of high-grade stainless steel } \\
\text { Maximum pressure rating up to } 10,000 \text { psi } 690 \text { bar for liquids }\end{array}$ \\
\hline Plastic Containers & $\begin{array}{c}\text { Fabco Plastics } \\
\text { (CYL TANK, } 16^{\prime \prime} \times 36^{*} \\
15 \text { IG HDPE OPEN TOP) }\end{array}$ & $\begin{array}{l}\text { Material: High density polyethylene } \\
\text { Size: inner diameter of } 16 \text { in }(40.6 \mathrm{~cm}) \text {, height } 24 \text { in }(61 \mathrm{~cm}) \\
\text { Capacity: } 68 \mathrm{~L}\end{array}$ \\
\hline
\end{tabular}




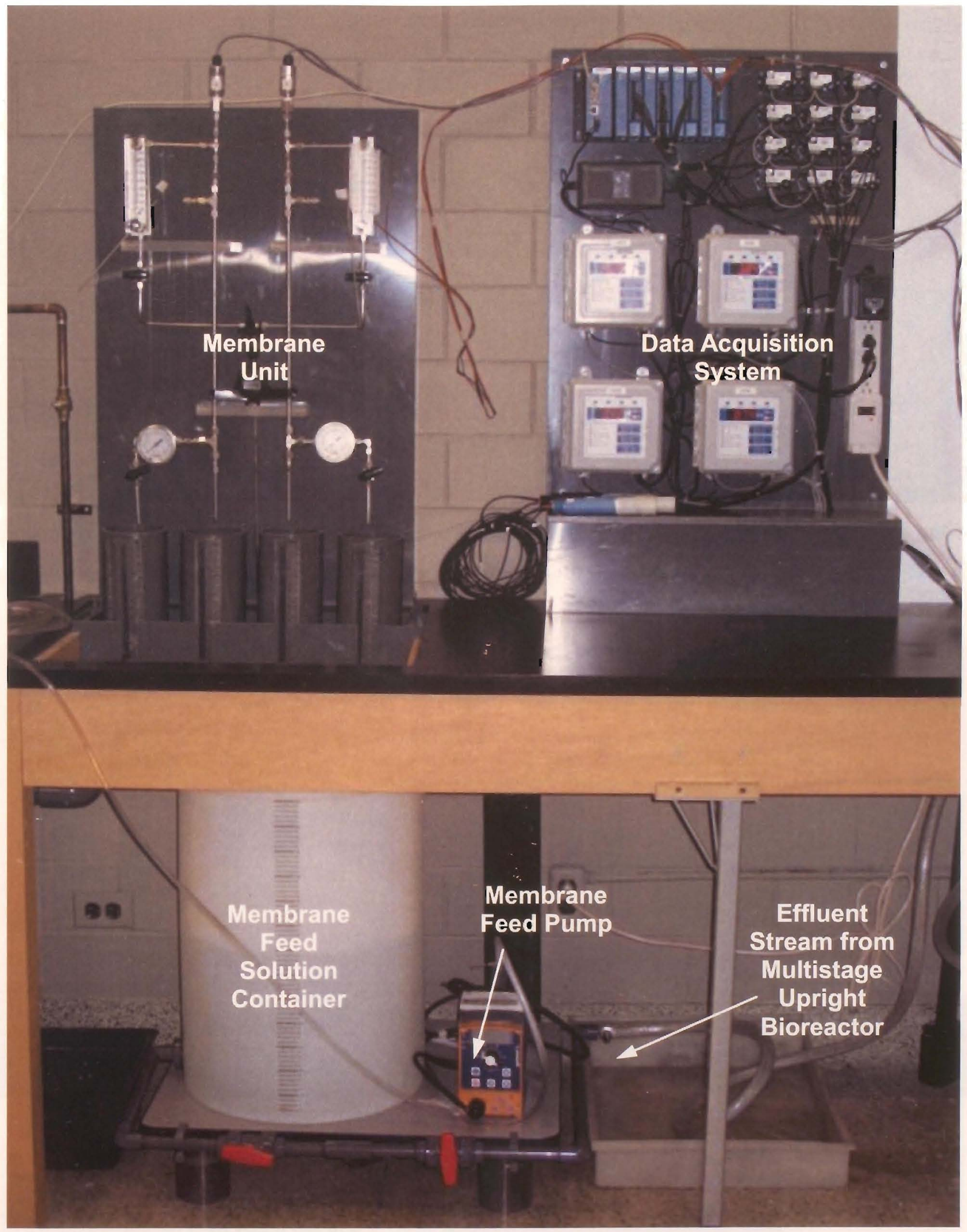

Figure 6.3 Photo of the ceramic membrane filtration apparatus and data acquisition 


\subsubsection{Membrane}

The ceramic membrane used in this study is a hollow fibre/tubular type of configuration produced by Media Process Technology, USA. They are manufactured for a wide range of temperatures and pressures and harsh chemical conditions. Table 6.2 gives details of the ceramic membranes and Figure 6.4 shows the ceramic membranes and housing. Previous studies by the manufacturer presents field tests and commercial installations from several long-term $(>1.5$ year) investigations, dealing with spent solvent recovery, used oil recycling, and drinking water treatment (Ciora and Liu, 2003).

The material of the membrane layer is alumina (aluminum oxide, $\mathrm{Al}_{2} \mathrm{O}_{3}$ ) with an average membrane thickness of approximately 10 microns supported with the same material but of a more porous structure, see Figure 6.5. Flow through the membrane (layer and support) is from out-to-in. That is, the feed passes tangentially along the inner surface of the membrane housing and outer surface of the membrane (feed side), towards the inner channel of the tubular membrane (permeate side) where the pressure is lower (atmospheric conditions) allowing permeate to pass through and be collected. It was given by the manufacturer that the membranes are hydrophilic.

Table 6.2 Description of the Media Process Technology ceramic membranes

\begin{tabular}{|c|c|}
\hline Company & Media Process Technology \\
\hline $\begin{array}{c}\text { Material of Membrane/Support } \\
\text { layer }\end{array}$ & a-alumina composite \\
\hline Membrane Dimensions & $\begin{array}{l}\text { Length: } 0.457 \mathrm{~m} \\
\text { Outer Diameter: } 5.7 \mathrm{~mm} \\
\text { Inner Diameter: } 3.5 \mathrm{~mm}\end{array}$ \\
\hline Membrane Pore Size & $0.05 \mu \mathrm{m}(500 \mathrm{~A})$ \\
\hline Porosity & $20 \%$ \\
\hline Material Density & $3.995 \mathrm{~g} / \mathrm{cm}$ \\
\hline $\begin{array}{l}\text { Surface Area } \\
\text { Inner } / \text { Outer }\end{array}$ & $0.0050 \mathrm{~m}^{2} / 0.0084 \mathrm{~m}^{2}$ \\
\hline Permeability Range & 152 to $203 \mathrm{~L} / \mathrm{hr} \cdot \mathrm{m}^{2}$ per atm \\
\hline Maximum Pressures & $<34 \mathrm{~atm}$ \\
\hline Cost Membrane & $\$ 10$ per $0.254 \mathrm{~m}$ \\
\hline
\end{tabular}




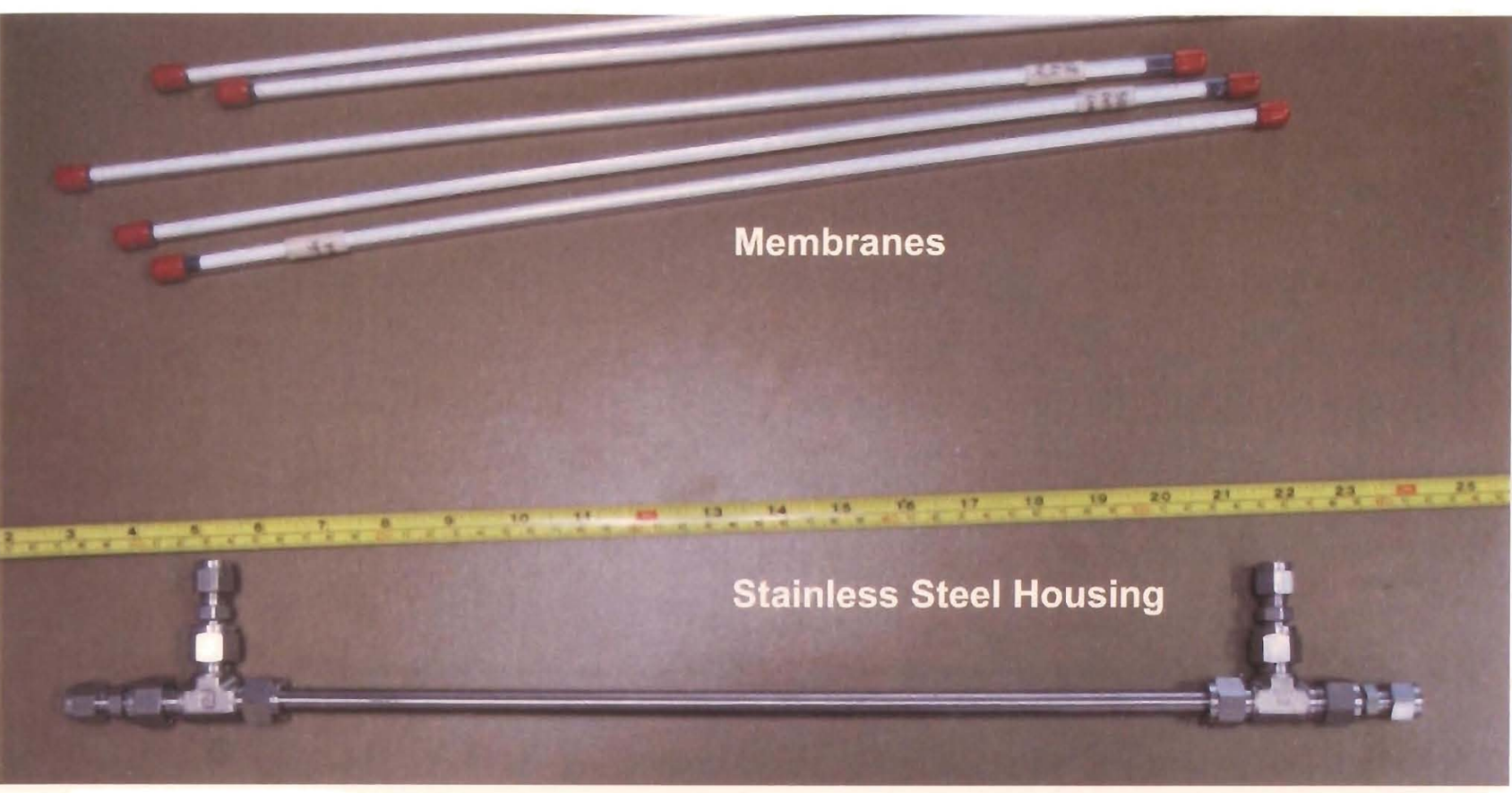

Figure 6.4 Photograph of the ceramic membranes (top) in plastic cases to protect membranes and the stainless steel membrane housing (bottom).

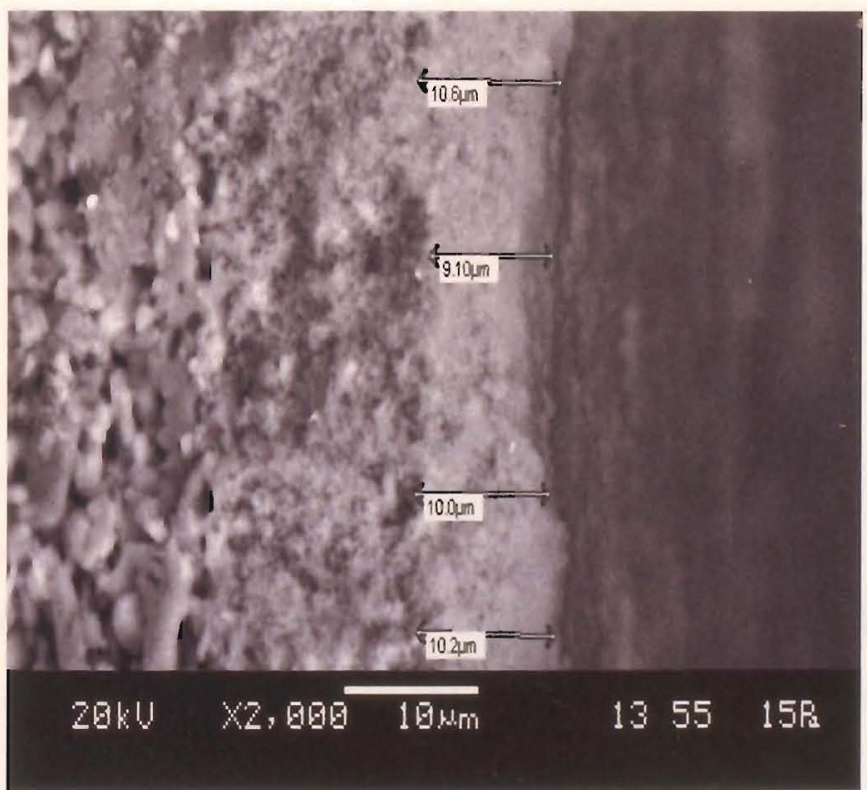

(a)

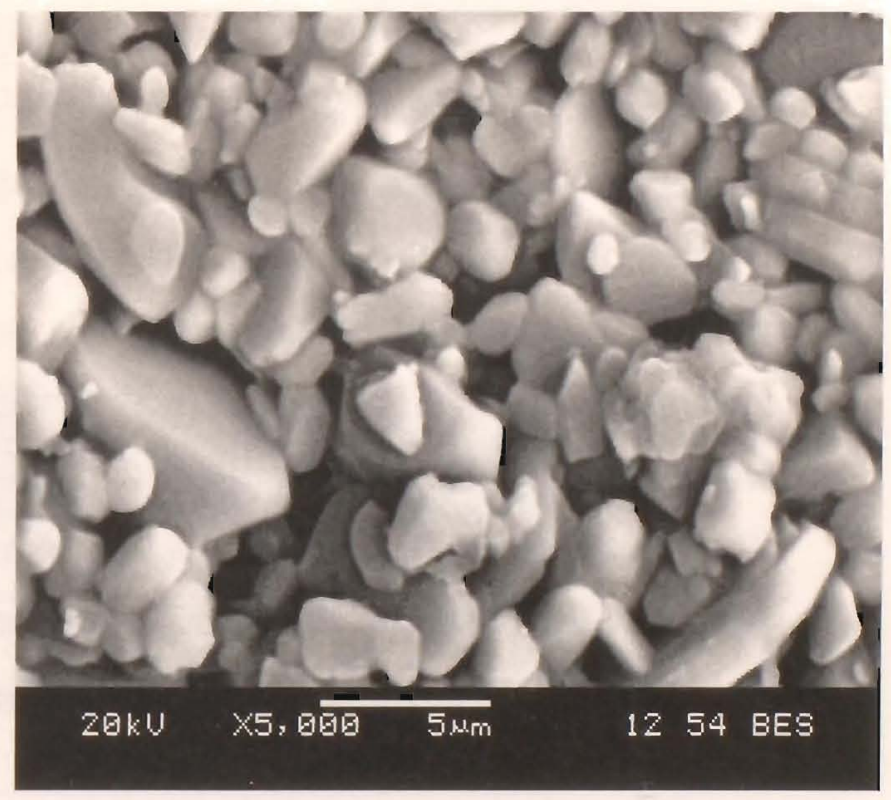

(b)

Figure 6.5 SEM image of the ceramic membrane (a) cross section showing membrane film layer thickness (average of $0.01 \mathrm{~mm}$ thick) and membrane support (left side) and (b) membrane surface at 5,000 times magnification. 


\subsubsection{Experimental Feeds}

\section{Distilled Water (Pure Water)}

Distilled water (i.e. pure water with impurities removed) was obtained from the Pure Water $\mathrm{C}-50^{\mathrm{TM}}$ Commercial Water Distillation System provided by the Chemical Engineering department. The distilled water obtained from this facility has a pH of $5.7 \pm 0.6$ and a temperature of $24.2 \pm 2.0^{\circ} \mathrm{C}$. In this study, the initial membrane permeability tests and solutions requiring dilution were carried out using this pure water.

\section{Aqueous Solution with Precipitate}

Experimental runs using an aqueous solution containing chemical precipitates was fed to the membrane unit. This simple solution of chemicals and make-up was based on the study by Hosni et al., 2007. The chemicals mixed with distilled water to make the aqueous precipitate solution are given as:

$$
\mathrm{Na}_{2} \mathrm{HPO}_{4}(\mathrm{aq})+\mathrm{CaCl}_{2}(\mathrm{aq})=\mathrm{CaHPO}_{4}(\mathrm{~s})+2 \mathrm{NaCl}(\mathrm{aq})
$$

Making sure the molar ratio of $\mathrm{Ca}$ and $\mathrm{PO}_{4}$ was greater than 3, developed that precipitate at room temperature. Analytical grade sodium phosphate, dibasic $\left(\mathrm{Na}_{2} \mathrm{HPO}_{4}\right)$ was first dissolved in distilled water followed by the addition of calcium chloride $\left(\mathrm{CaCl}_{2}\right)$. Amounts of these chemicals were weighed to make feed solutions of various concentrations, specifically about 20,50 and $100 \mathrm{mg}$ of total suspended solids per litre of solution. The solution batches had a pH of about 6 and temperature about $25^{\circ} \mathrm{C}$. Particle size analysis of the aqueous solution (taken after more than 6 hours since first making the solution) was determined to have a range from 1.9 to 631 microns (see Appendix B for particle size distribution results). It was observed that over time (a few hours) the precipitate would agglomerate and settle. Therefore, the solution was fed within the first 3 hours of filtration and manually stirred for mixing.

\section{Effluent Wastewater from Bioreactor}

A synthetic wastewater solution was obtained from the CUBEN effluent. The composition of the wastewater is shown in Table 6.3. 
Table 6.3 Composition of the effluent from CUBEN

\begin{tabular}{|c|c|}
\hline Parameter & Composition \\
\hline $\mathrm{BOD}_{5}$ & $<5 \mathrm{mg} / \mathrm{L}$ \\
\hline $\mathrm{COD}$ & $<10 \mathrm{mg} / \mathrm{L}$ \\
\hline $\mathrm{TSS}$ & $<200 \mathrm{mg} / \mathrm{L}$ \\
\hline $\mathrm{NO}_{3}$ & $<0.5 \mathrm{mg} / \mathrm{L}$ \\
\hline $\mathrm{TP}$ & $<0.1 \mathrm{mg} / \mathrm{L}$ \\
\hline $\mathrm{DO}$ & $3-4 \mathrm{mg} / \mathrm{L}$ \\
\hline $\mathrm{pH}$ & $6.5-8$ \\
\hline Turbidity & $<1000$ \\
\hline
\end{tabular}

\subsubsection{Cleaning Solutions}

There were various cleaning solutions used in this experiment, they are tabulated in Table 6.4. In all cases, the chemicals were diluted in distilled water to make cleaning solution concentrations of less than $1 \%$ by weight.

Table 6.4 List of chemicals utilized for cleaning

\begin{tabular}{|c|c|c|}
\hline $\begin{array}{c}\text { Cleaning solutions } \\
\text { (concentration) }\end{array}$ & $\begin{array}{c}\text { Temperature } \\
\left({ }^{\circ} \mathrm{C}\right)\end{array}$ & $\mathrm{pH}$ \\
\hline Distilled water & -24.2 & $\sim 5.5$ \\
\hline Hydrochloric Acid $(<1 \% \mathrm{wt})$ & $23-26$ & Acid-type \\
\hline Acetic Acid $(<1 \% \mathrm{wt})$ & $23-28$ & Acid-type \\
\hline Sodium Hydroxide $(<1 \% \mathrm{wt})$ & $23-26$ & Base-type \\
\hline
\end{tabular}




\subsection{Methods}

The evaluation of the membranes was based on the evaluation of four characteristics. The experimental protocol is illustrated in the four flow charts of Figure 6.6. The experiments started with calibrating the newly built unit.

Section 6.2.1 describes the method defined as Pure Water Flux Test (Membrane Permeability Determination). The method determines the flux through the membrane using water at various flow rates and pressures. Based on the manufacturers' permeate flux values (Table 6.5), the water flux tests determined the range of permeate flux and pressures reachable with the specific apparatus built here in this experiment. This calibration of the unit helped set operating conditions (i.e. applicable initial flow rates and pressures) for the subsequent experiments. Next, it was needed to evaluate the effects of filtering a feed solution containing precipitate at various operating conditions, flow rates and pressures.

In Section 6.2.2, Membrane Filtration and Fouling Trials with Water and Aqueous Solution Feed the experimental method for filtering the aqueous solution containing precipitate is described. The aqueous feed solution with precipitate was made up in batches at three different concentrations (of suspended solids) and filtered at five different feed flow rates (Table 6.6). For every experimental run, new membranes were set-up in the apparatus and an initial water flux test was performed, at constant operating pressures, before the feed solution filtration.

In Section 6.2.3, Cleaning of Fouled Membranes by Aqueous Solution Feed, the effects of membrane fouling during filtration were revealed and hence a cleaning protocol was able to be implemented. With the same aqueous solution at constant initial concentration, it was necessary to experiment the membrane cleaning/regeneration (Section 6.2.5) of the fouled membranes. Therefore, to test the effects of different cleaning protocols (e.g. physical, chemical, etc) and determine if membrane regeneration was possible, the recovery was determined by applying a water flux test after each cleaning and comparing the results to the initial water flux results that were done when the membranes were newly installed. 
Finally, in Section 6.2.4, Cleaning of Fouled Membranes by CUBEN Effluent, experiments of filtration with a wastewater feed from the bioreactor was investigated. The membrane cleaning and regeneration (Section 6.2.5) were also studied with this feed wastewater. The next few sections detail the experimental procedure and the notation may be referred to Figure 6.7.

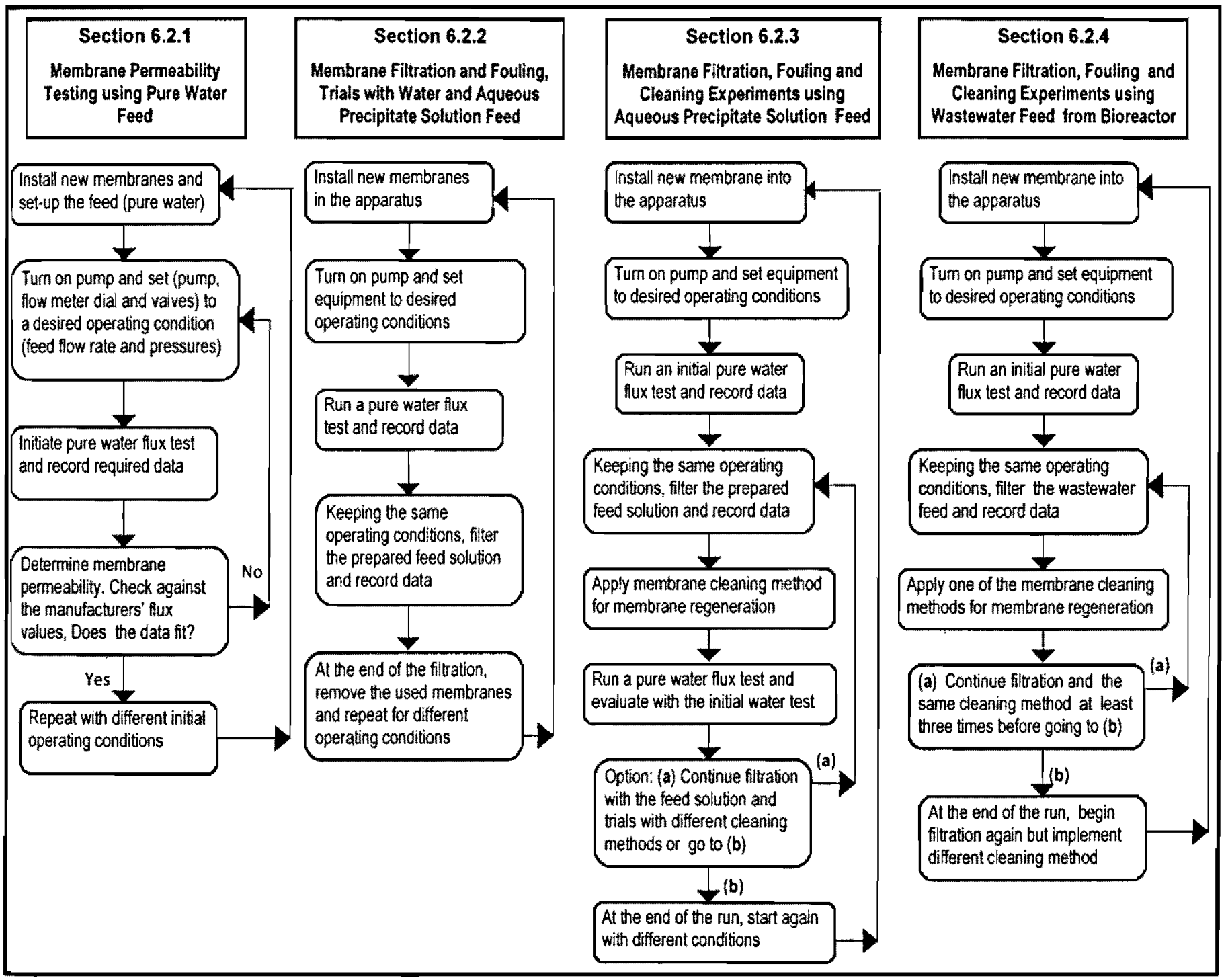

Figure 6.6 Brief depiction of the experimental procedure that is described in the next few sections 


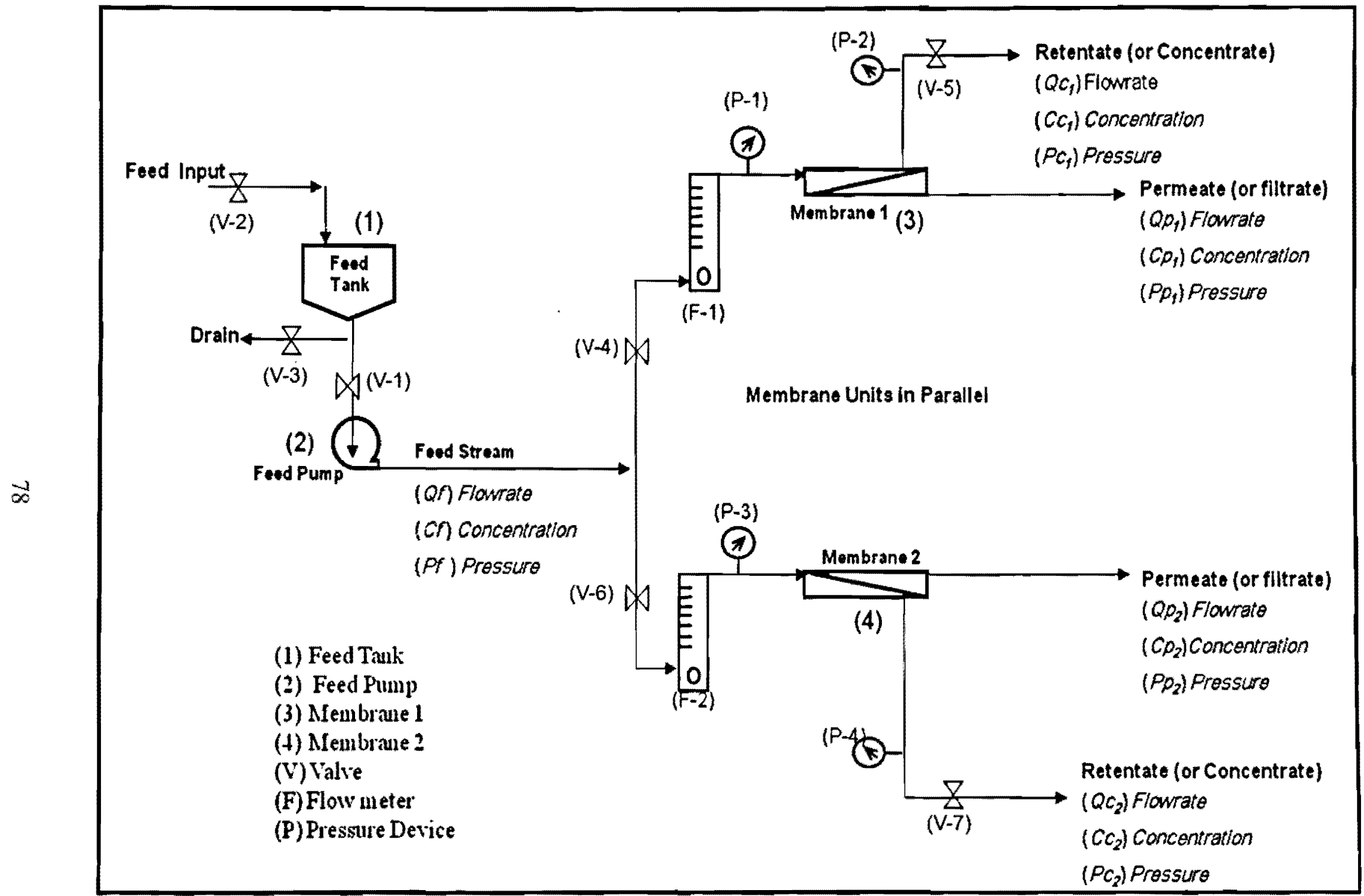

Figure 6.7 Flow diagram of the membrane filtration unit with two parallel streams 


\subsubsection{Pure Water Flux Test (Membrane Permeability Determination)}

For quality control and to verify effective cleaning, the membrane permeability test was carried out and measurements were compared to that of the manufacturer specifications. The steps to obtain water permeability are as follows:

1. Install new/clean membranes into the apparatus.

2. Fill the feed container (1) with distilled water.

3. Make sure all the valves are fully open, they must be adjusted later.

4. Run the computer program to record/log online data.

5. Turn on the feed pump (2) and circulate water through the apparatus for approximately $3-5$ minutes at a standard operating feed pressure of $1 \mathrm{~atm}$ and an initial flow rate of $1.5 \mathrm{~L} / \mathrm{hr}$. This will ensure that the membranes are fully wet.

6. Very slowly increase the feed flowrate up to the desired operating value. This can be done from the pump dial or from the knobs on the flow meter (F).

7. At the same time, adjust the valves, $\mathbf{V - 5}$, and $\mathbf{V - 7}$, to regulate the pressure inside the unit.

8. Let the water filter for about one hour, all the while recording the filtrate volume, retentate volume and retentate pressure over fixed the time intervals. The temperature, feed pressure and $\mathrm{pH}$ are recorded via the data acquisition.

9. At the end, stop the pump and the computer program.

10. From the data recorded, calculate permeability by dividing the filtrate flowrate by the transmembrane pressure drop and the membrane area at a specific time.

For example, from an experimental run suppose the filtrate flowrate recorded was 2 $\mathrm{L} / \mathrm{hr}$ at a feed pressure of $1 \mathrm{~atm}$. Further, the surface area of the membrane exposed to the feed liquid is $0.008 \mathrm{~m}^{2}$, then the permeability is calculated as,

$$
\begin{aligned}
\text { Permeability } & =(2 \mathrm{~L} / \mathrm{hr}) /\left(0.008 \mathrm{~m}^{2}\right) /(1 \mathrm{~atm}) \\
& =250 \mathrm{~L} / \mathrm{hr} \cdot \mathrm{m}^{2} \text { per atm }
\end{aligned}
$$

11. Check the calculated values against the manufacturer's specifications and any prior membrane process runs.

12. Repeat the procedure for different operating conditions. 
As an example, if the manufacturer's value of permeability is $253.3 \mathrm{~L} /$ hour $\mathrm{m}^{2}$ per atm, then the uncertainty or deviation for the above example would be

$$
\begin{aligned}
& \% \text { deviation }=\frac{\mid(\text { Experimental value }- \text { Supplier's value }) \mid}{\text { Supplier's value }} \times 100 \% \\
& =(253.3-250) / 253.3 \times 100 \% \\
& =1.3 \%
\end{aligned}
$$

It is given that the membranes have a specified permeate flux range of 151.99 to $202.65 \mathrm{~L} /$ hour $\mathrm{m}^{2}$ per atm ( 150 to $200 \mathrm{~L} / \mathrm{m}^{2}$.hour per bar) which is the minimum to maximum membrane permeability, respectively, that is reported by the manufacturer, the following predicted values of permeate llowrate in Table 1 are achievable with the corresponding pressure applied.

Table 6.5 Manufacturer's membrane flux values attainable at the specified transmembrane pressure for pure water

\begin{tabular}{|c|c|c|}
\hline $\begin{array}{c}\text { Applied pressure or } \\
\text { feed pressure, TMP } \\
\text { (atm) }\end{array}$ & $\begin{array}{c}\text { Minimum } \\
\text { Permeate Flux } \\
\left(\mathrm{L} / \mathrm{hr}^{2} / \mathrm{m}^{2}\right)\end{array}$ & $\begin{array}{c}\text { Maximum Permeate } \\
\text { Flux } \\
\left(\mathrm{L} / \mathrm{hr} / \mathrm{m}^{2}\right)\end{array}$ \\
\hline 0.2 & 30.39 & 40.53 \\
\hline 0.4 & 60.79 & 81.06 \\
\hline 0.5 & 75.99 & 101.32 \\
\hline 0.6 & 91.19 & 121.59 \\
\hline 0.8 & 121.59 & 162.12 \\
\hline 1 & 151.98 & 202.65 \\
\hline 1.2 & 132.38 & 243.18 \\
\hline 1.4 & 212.78 & 283.71 \\
\hline 1.5 & 227.98 & 303.97 \\
\hline 1.6 & 243.18 & 324.24 \\
\hline 1.8 & 273.57 & 364.77 \\
\hline 2 & 303.97 & 405.30 \\
\hline 2.5 & 379.96 & 506.62 \\
\hline 3 & 455.96 & 607.95 \\
\hline 3.5 & 531.95 & 709.27 \\
\hline 4 & 607.95 & 810.60 \\
\hline & & \\
\hline
\end{tabular}




\subsubsection{Filtration Trials with Water and Aqueous Solution Feed}

For the filtration trials in this part, the experiments were done to determine the effects of membrane fouling. A water flux test was performed for all newly installed membranes. New membranes were installed for each run; see Table 6.6 which shows a matrix of the number of runs and operating conditions (i.e., feed flowrate, $Q_{F}$, and feed concentration, $C_{F}$ ) of each run. The table also shows what parameters were recorded during the run.

Trials with the aqueous precipitated feed solution involve the following procedure:

1. Execute a pure water flux test (Section 6.2.1) with predetermined initial feed flow rate and pressure. Make sure not to change the valve settings since they are now set for the aqueous feed filtration.

2. Drain out the water from the feed container (1) and fill it with the aqueous feed solution.

3. Start the computer program and the feed pump (2). Although the settings (i.e. feed flow rate and adjustment of any valves, knobs or dials) should already be set from step 1, it is possible to make small adjustments such that pressure is kept constant.

For example, for Run 1 (in the matrix of Table 6.6) with an initial fixed feed concentration of about $20 \mathrm{mg}$ of TSS/L, adjust the feed flowrate to the desired initial value of $1.5 \mathrm{~L} /$ hour by viewing the flowmeter.

4. For all filtrate and retentate effluents, record the flowrates, pressures, and other pertinent measurements by time-collection. Collect samples on a timely-basis during filtration to measure concentration.

5. Continue observation and keep recording data until a steady decrease in permeate flowrate or increase in pressure is observed.

6. Stop the pump and computer program at the end of the filtration run.

7. Drain the remaining feed solution and rinse with warm water.

8. Repeat the procedure from the beginning for a different run.

As already mentioned, the matrix (Table 6.6) plans out the experiments, which consists of 12 runs with various feed flowrates and total suspended solids concentrations, given in the first column to the right and the first row from the top, respectively.

The runs were implemented in pairs, meaning, since the apparatus has two membrane units (units 1 
and 2) in parallel, two runs were able to be implemented at one time. Therefore, the denotation, R1,2, means Run 1 and Run 2 were implemented at the same time with the corresponding differences in operating conditions. For example, Run 1 was at a constant initial feed concentration of $20 \mathrm{mg}$ of TSS/L at a feed flow rate of $1.5 \mathrm{~L} /$ hour and feed pressure of about $0.6 \mathrm{~atm}$ was executed. While Run 2 was at a constant initial feed concentration of $20 \mathrm{mg}$ of TSS/L at a feed flow rate of $2.1 \mathrm{~L}$ hour and feed pressure of about $0.9 \mathrm{~atm}$ applied.

Table 6.6 Matrix of the aqueous solution trial runs.

Various initial feed concentration, $C_{F}$, (first column) and feed flowrate, $Q_{F}$, (top row) parameters were evaluated. Inside each box shows the values recorded during the run which were: time, $t$; flowrates, $Q$; Concentration, $C$; and pressures, $P$. Other denotations are as follows: permeate $(p)$, retentate $(c)$, membrane unit $\left(m_{i}\right)$ where $i$ is equal to either 1 or 2 . Additionally, temperature and the $\mathrm{pH}$ were measured.

\begin{tabular}{|c|c|c|c|c|c|c|}
\hline$C_{k}(\mathrm{mgTSS} / \mathrm{L})$ & \multicolumn{2}{|c|}{$\approx 20$} & \multicolumn{2}{|c|}{$\approx \mathbf{5 0}$} & \multicolumn{2}{|c|}{$\approx 100$} \\
\hline 1.5 & $\begin{array}{ll}\text { Run 1 } \\
\mathrm{t} \\
Q_{F i} & C \\
Q_{P i} & C_{f} \\
Q_{C i} & C_{\ell}\end{array}$ & $\begin{array}{l}P_{f i} \\
P_{P i} \\
P_{C i}\end{array}$ & $\begin{array}{ll}\text { Run } 5 \\
\mathbf{t} \\
Q_{F i} & C_{F} \\
Q_{P i} & C_{P} \\
Q_{C i} & C_{C}\end{array}$ & $\begin{array}{l}P_{F \bar{F}} \\
P_{P t} \\
P_{C i}\end{array}$ & $\begin{array}{ll}\text { Run 9 } & \\
t & \\
Q_{F i} & C_{F i} \\
Q_{P i} & C_{P i} \\
Q_{C i} & C_{C i}\end{array}$ & $\begin{array}{l}P_{F i} \\
P_{p i} \\
P_{C i}\end{array}$ \\
\hline 2.1 & $\begin{array}{ll}\text { Run } 2 & \\
\mathrm{t} & \\
Q_{F i} & C \\
Q_{P i} & C_{P} \\
Q_{C i} & C_{C}\end{array}$ & $\begin{array}{l}P_{F i} \\
P_{P y} \\
P_{C i}\end{array}$ & 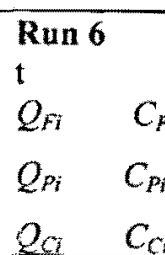 & $\begin{array}{l}P_{F i} \\
P_{P_{i}} \\
P_{C i}\end{array}$ & $\begin{array}{ll}\text { Run } & \text { 10 } \\
t & \\
Q_{F i} & C_{F i} \\
Q_{P i} & C_{F i} \\
Q_{C i} & C_{C i}\end{array}$ & $\begin{array}{l}P_{F i} \\
P_{P i} \\
P_{C i}\end{array}$ \\
\hline 2.7 & $\begin{array}{ll}\text { Run 3 } & \\
\mathrm{t} & \\
Q_{F i} & C \\
Q_{P_{i}} & C_{P} \\
Q_{C i} & C_{C}\end{array}$ & $\begin{array}{l}P_{F i} \\
P_{P i} \\
P_{C i}\end{array}$ & $\begin{array}{ll}\operatorname{Run} 7 \\
\mathrm{t} & \\
Q_{F i} & C_{F} \\
Q_{P i} & C_{P_{i}} \\
Q_{C i} & C_{C i}\end{array}$ & $\begin{array}{l}P_{F i} \\
P_{P i} \\
P_{C i}\end{array}$ & $\begin{array}{ll}\text { Run } 11 \\
t & \\
Q_{F i} & C_{F i} \\
Q_{P i} & C_{P i} \\
Q_{C i} & C_{C}\end{array}$ & $\begin{array}{l}P_{F i} \\
P_{P i} \\
P_{C}\end{array}$ \\
\hline 3.3 & $\begin{array}{ll}\text { Run 4 } \\
\mathrm{t} & \\
Q_{F i} & C_{C} \\
Q_{P i} & C_{P} \\
Q_{C i} & C_{C}\end{array}$ & $\begin{array}{l}P_{f i} \\
P_{P_{i}} \\
P_{C i}\end{array}$ & $\begin{array}{ll}\text { Run } 8 & \\
\mathrm{t} & \\
Q_{F i} & C_{F} \\
Q_{P i} & C_{P_{i}} \\
Q_{C i} & C_{C}\end{array}$ & $\begin{array}{l}P_{F i} \\
P_{P i} \\
P_{C}\end{array}$ & $\begin{array}{ll}\text { Run 12 } & \\
\mathrm{t} & \\
Q_{f i} & C_{f i} \\
Q_{P i} & C_{P i} \\
Q_{C i} & C_{C}\end{array}$ & $\begin{array}{l}P_{f i} \\
P_{P_{i}} \\
P_{C i}\end{array}$ \\
\hline
\end{tabular}




\subsubsection{Filtration, Fouling and Cleaning Trials with Aqueous Solution as Feed}

As shown in Figure 6.5 of the brief experimental protocol diagram, this part of the experiments was similar to the previous section. However, the difference in this case was that a cleaning method (Section 6.2.5) was applied to the membranes after filtration of the feed solution. Here is the experimental procedure that was performed.

1. Execute a pure water flux test (Section 6.2.1) with predetermined initial feed flow rate and pressure. Make sure not to change the valve settings since they are now set for the aqueous feed filtration.

2. Drain out the water from the feed container (1) and fill it with the aqueous feed solution.

3. Start the computer program and the feed pump (2) to start filtration. If necessary, make small adjustments such that pressure is kept constant by controlling the pump speed dial, flow meter (F) knob or any of the valves V-5 or V-7.

4. For all filtrate and retentate effluents, record the flowrates, pressures, and other pertinent measurements by time-collection. Collect samples on a timely-basis during filtration to measure concentration.

5. Continue observation and keep recording data until a steady decrease in permeate flowrate or increase in pressure is observed.

6. Stop the pump and computer program at the end of the filtration run.

7. Drain the remaining feed solution and rinse with warm water.

8. Implement a cleaning method (Section 6.2.5 and Table 6.7).

9. Perform water flux test (Section 6.2.1).

10. Repeat the procedure from step 2 while applying different cleaning methods each time.

From the previous section optimum experimental conditions (feed flow rate, feed concentration and applied pressure) were determined, as well as the length of time to observe membrane fouling which determines the cleaning regimen. As already stated, feed was introduced and fed to both membranes of the parallel configuration. During all filtrations relevant data was recorded or logged on a timely basis, this included time, pressure, flowrates, temperature and $\mathrm{pH}$. Samples were collected during filtration of the feed solutions to ensure membrane separation. Various cleaning protocols were implemented to determine the best cleaning method. 


\subsubsection{Filtration, Fouling and Cleaning Trials with Wastewater Feed}

In this section, wastewater is filtered through the membranes and a cleaning method (Section 6.2.5) is implemented. The procedure was as follows:

1. Execute a pure water flux test (Section 6.2.1) with predetermined initial feed flow rate and pressure. (Make sure not to change the valve settings since they are now set for the wastewater filtration operation).

2. Drain out the pure water from the feed container (1) and fill it with the wastewater feed.

3. Start the computer program and the feed pump (2) to start filtration of the wastewater. If necessary, make small adjustments such that pressure is kept constant by controlling the pump speed dial, flow meter (F) knob or any of the valves V-5 or V-7.

4. For all filtrate and retentate effluents, record the flowrates, pressures, and other pertinent measurements by time-collection. Collect samples on a timely-basis during filtration to measure concentration.

5. Continue observation and keep recording data until a steady decrease in permeate flowrate or increase in pressure is observed.

6. Stop the pump and computer program at the end of the wastewater filtration run.

7. Drain the remaining feed tank and rinse with warm water and distilled water.

8. Implement a cleaning method (Section 6.2.5, Table 6.7)

9. Repeat steps 3 through to step 8 of this procedure four times with applying the same cleaning method in step 8 .

10. Perform water flux test (Section 6.2.1).

For the experiments using wastewater feed, one feed flow rate of approximately $2.7 \mathrm{~L} / \mathrm{hr}$ was chosen to simplify the procedure. This section involved the above procedure but applying numerous cleaning methods. The results are discussed in Chapter 7. 


\subsubsection{Membrane Cleaning / Regeneration}

This section pertains to Sections 6.2.3 and 6.2.4 procedures. Membrane cleaning experiments were examined using both physical and chemical methods. The physical methods entailed backflushing and chemically enhanced backflushing with various cleaning solutions, as mentioned earlier in Section 6.1.4. The chemical method involved soaking the membrane for three hours in the cleaning solutions. Table 6.7 tabulates the experimental cleaning solutions and methods conducted and the conditions for each cleaning.

For the backflush method of cleaning, the membranes are installed in reverse (i.e. the o-ring placed at the top for seal, whereas during filtration o-rings are installed at the bottom, see Figure 6.8 for the installation of the membrane and housing during filtration, and Figure 6.9 for during backflush. The applied pressure and flowrates were recorded during the backflush procedure.

After a cleaning treatment was completed flux recovery and suspended solids rejection were checked for membrane regeneration effectiveness. This inspection of flux recovery and solids rejection will be carried out by the membrane permeability test and then with a filtration run where suspended solids concentration of the effluents are measured. 
Table 6.7 Cleaning methods experimented

\begin{tabular}{|c|c|c|c|c|}
\hline \multirow{2}{*}{ Number } & Cleaning Solution & $\begin{array}{c}\text { Type of Cleaning } \\
\text { Method }\end{array}$ & \multicolumn{2}{|c|}{ Conditions } \\
\hline & \multirow{6}{*}{$\begin{array}{l}\text { Pure (distilled) } \\
\text { Water }\end{array}$} & \multirow{6}{*}{ Backflush } & Flow rate & $1.5 \mathrm{~L} / \mathrm{hr}$ \\
\hline \multirow{5}{*}{1} & & & Pressure & $1 \mathrm{~atm}$ \\
\hline & & & Temperature & $\approx 24.5^{\circ} \mathrm{C}$ \\
\hline & & & $\mathrm{pH}$ & $\approx 6$ \\
\hline & & & Concentration & $n / a$ \\
\hline & & & Time & 30 minutes \\
\hline \multirow{6}{*}{2} & \multirow{6}{*}{ Hydrochioric Acid } & \multirow{6}{*}{$\begin{array}{l}\text { Chemically } \\
\text { Enhanced } \\
\text { Backflush }\end{array}$} & Flow rate & $1.5 \mathrm{~L} / \mathrm{hr}$ \\
\hline & & & Pressure & $0.5-1 \mathrm{~atm}$ \\
\hline & & & Temperature & $\approx 25.5^{\circ} \mathrm{C}$ \\
\hline & & & $\mathrm{pH}$ & 3 \\
\hline & & & Concentration & $<1 \% w t$ \\
\hline & & & Time & 30 minutes \\
\hline \multirow{5}{*}{3} & \multirow{5}{*}{ Hydrochloric Acid } & \multirow{5}{*}{ Soaking } & Pressure & $1 \mathrm{~atm}$ \\
\hline & & & Temperature & $\approx 255^{\circ} \mathrm{C}$ \\
\hline & & & $\mathrm{pH}$ & 3 \\
\hline & & & Concentration & $<1 \% w t$ \\
\hline & & & Time & 3 hours \\
\hline \multirow{6}{*}{4} & \multirow{6}{*}{ Acetic Acid } & \multirow{6}{*}{$\begin{array}{l}\text { Chemically } \\
\text { Enhanced } \\
\text { Backflush }\end{array}$} & Flow rate & $1.5 \mathrm{~L} / \mathrm{hr}$ \\
\hline & & & Pressure & $0.5-1 \mathrm{~atm}$ \\
\hline & & & Temperature & $\approx 25.5^{\circ} \mathrm{C}$ \\
\hline & & & $\mathrm{pH}$ & 4 \\
\hline & & & Concentration & $<1 \% \mathrm{wt}$ \\
\hline & & & Time & 30 minutes \\
\hline \multirow{5}{*}{5} & \multirow{5}{*}{ Acetic Acid } & \multirow{5}{*}{ Soaking } & Pressure & $1 \mathrm{~atm}$ \\
\hline & & & Temperature & $\approx 25.5^{\circ} \mathrm{C}$ \\
\hline & & & $\mathrm{pH}$ & 4 \\
\hline & & & Concentration & $<1 \% w t$ \\
\hline & & & Time & 3 hours \\
\hline \multirow{6}{*}{6} & \multirow{6}{*}{ Sodium Hydroxide } & \multirow{6}{*}{$\begin{array}{l}\text { Chemically } \\
\text { Enhanced } \\
\text { Backflush }\end{array}$} & Flow rate & $1.5 \mathrm{Lhr}$ \\
\hline & & & Pressure & $0.5-1 \mathrm{~atm}$ \\
\hline & & & Temperature & $\approx 25.5^{\circ} \mathrm{C}$ \\
\hline & & & $\mathrm{pH}$ & 10 \\
\hline & & & Concentration & $<1 \% w t$ \\
\hline & & & Time & 30 minutes \\
\hline \multirow{5}{*}{7} & \multirow{5}{*}{ Sodium Hydroxide } & \multirow{5}{*}{ Soaking } & Pressure & $1 \mathrm{~atm}$ \\
\hline & & & Temperature & $\approx 25.5^{\circ} \mathrm{C}$ \\
\hline & & & $\mathrm{pH}$ & 10 \\
\hline & & & Concentration & $<1 \% w t$ \\
\hline & & & Time & 3 hours \\
\hline
\end{tabular}


(a)

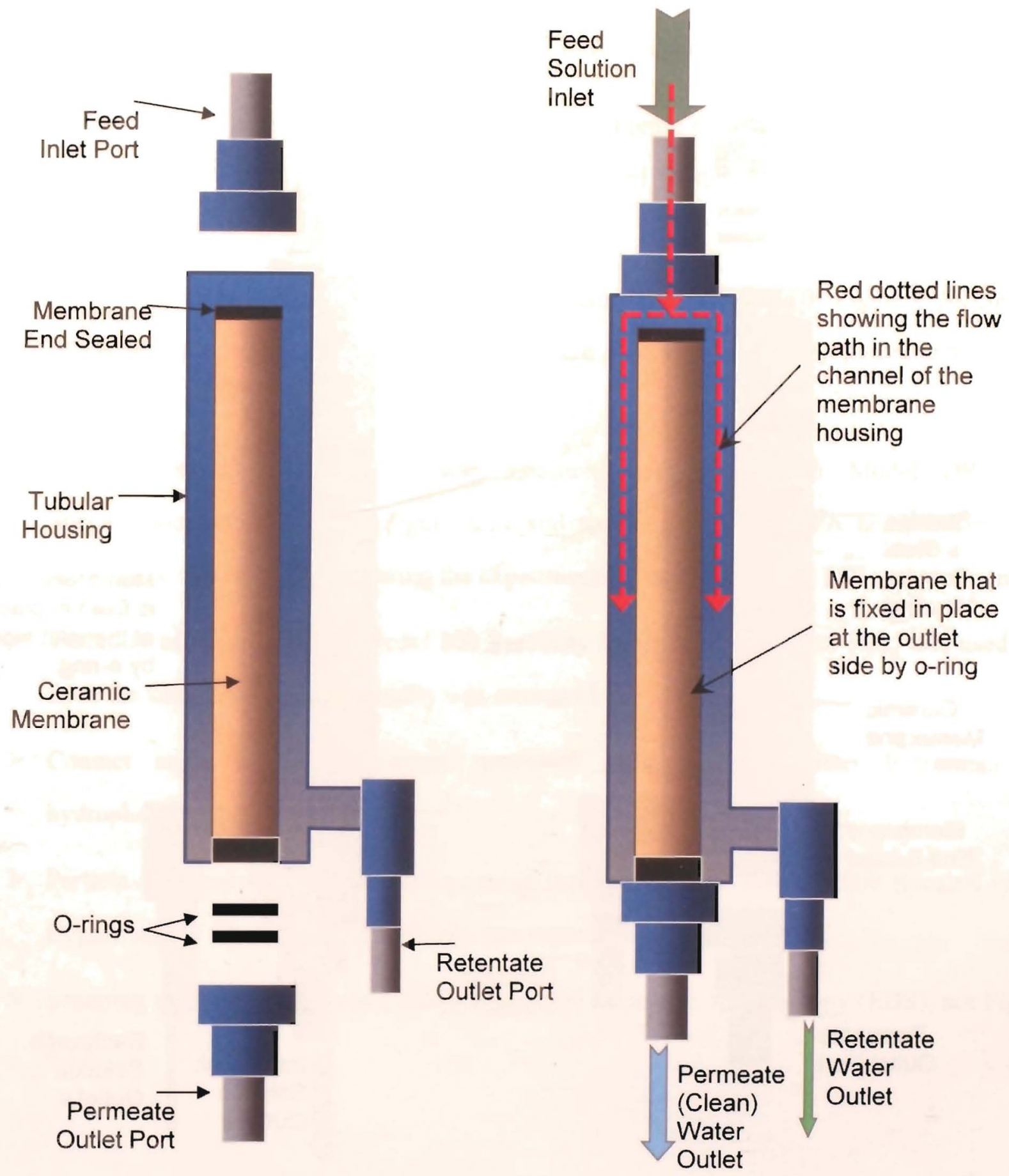

(b)

Figure 6.8 Diagram of ceramic Tubular Membrane Module for Filtration Mode Operation, showing (a) parts of the membrane unit and (b) direction of the flow when assembled. 
(a)

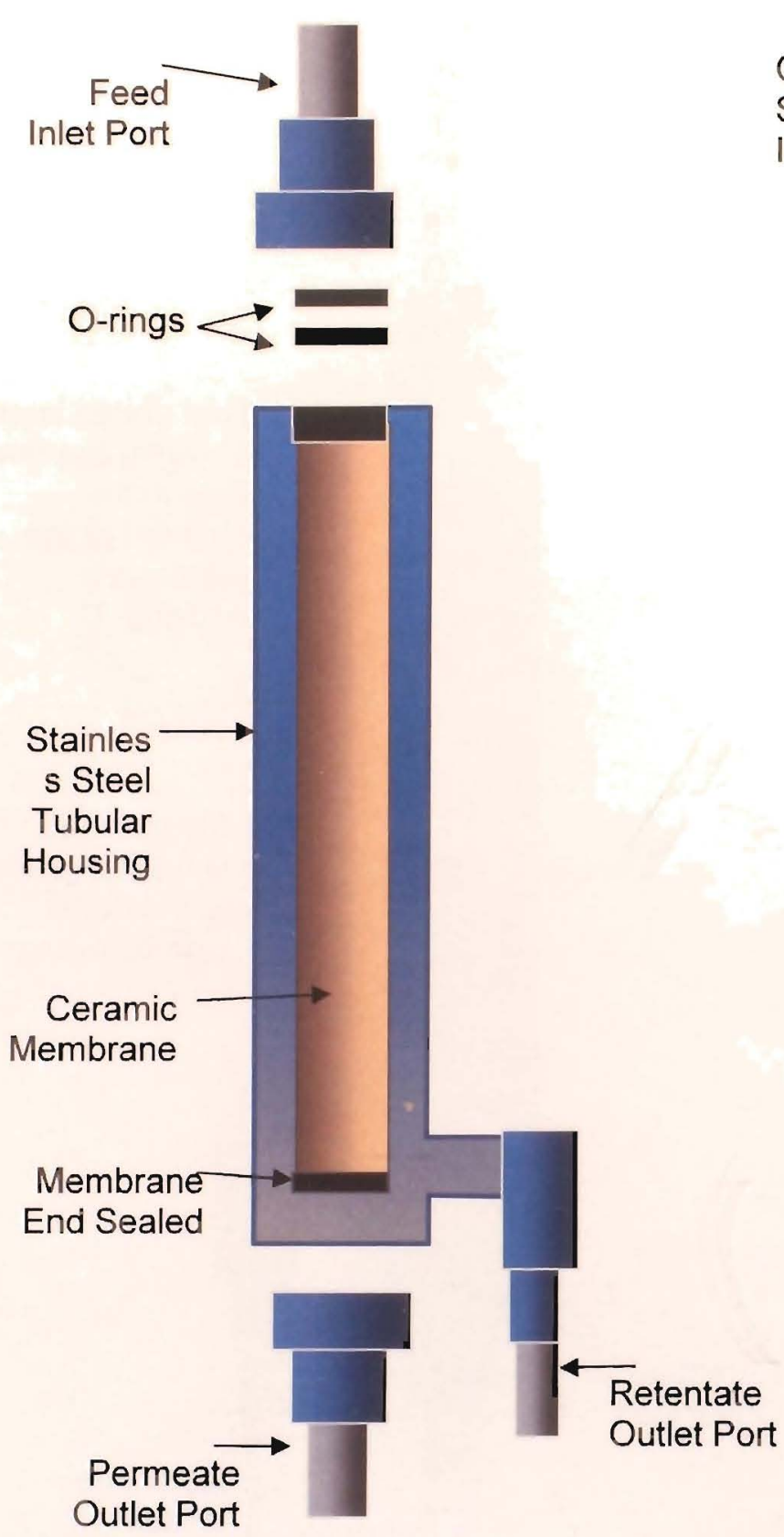

(b)

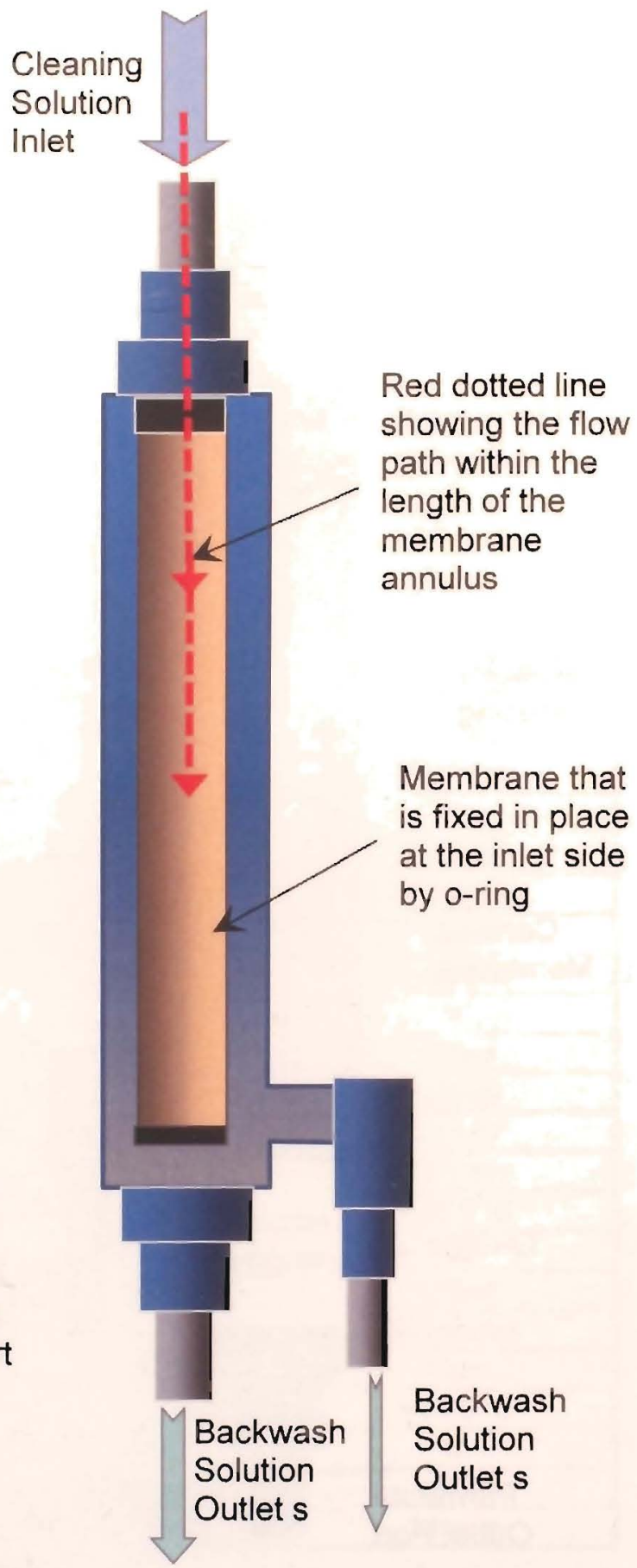

Figure 6.9 Diagram of Ceramic Tubular Membrane Module for Backwash Cleaning Mode Operation, showing (a) parts of the membrane unit and (b) direction of the flow when assembled. 


\subsection{Analytical Methods}

The analytical methods followed the Standard Methods for the Examination of Water and Wastewater or Environmental Protection Agency, U.S.EPA methods:

$>\mathrm{pH}$ measurements using the online $\mathrm{pH}$ sensor, see Figure 6.10. The sensors were manually inserted into the liquid to be measured, that included all the feed solutions, permeate and retentate effluents and cleaning solutions.

$>$ Temperature was measured using the online thermocouple sensor, see Figure 6.10. Similar to the $\mathrm{pH}$ sensors, the temperature sensors were able to be manually placed into various container.

$>$ Total suspended solids (TSS) was measured using the Hach Model DR 2700 Spectrophotometer shown in Figure 6.11 and applying TSS U.S.EPA analytical method provided. Collected samples during the experiments were analyzed for TSS measurements.

$>$ Turbidity using the VWRß Model 800 Turbidity Meter, seen in Figure 6.12, was used and from the samples collected turbidity was measured.

$>$ Contact angle of the membrane measured using the Rame-Hart Instrument for hydrophobicity, see Figure 6.13.

$>$ Particle size analysis of feed solution using the Malvern Mastersizer 2000 (located in the Department of Chemistry and Biology), see Figure 6.14.

Scanning electron microscopy (SEM) and energy dispersive spectroscopy (EDS), see Figure 6.15 . 

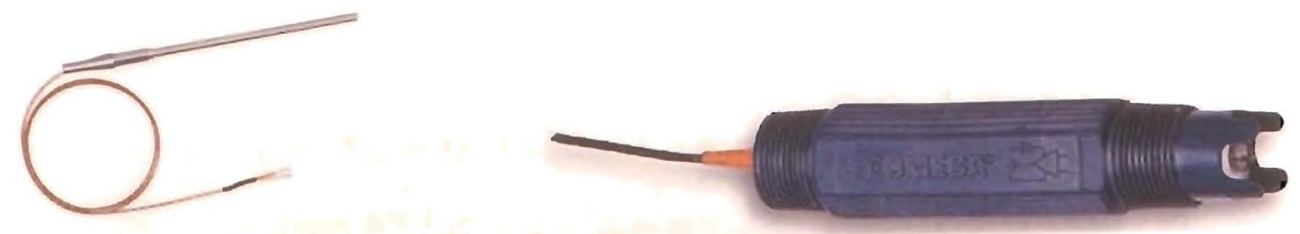

Figure 6.10 Temperature (left) and $\mathrm{pH}$ (right) sensors that are connected to the data acquisition system

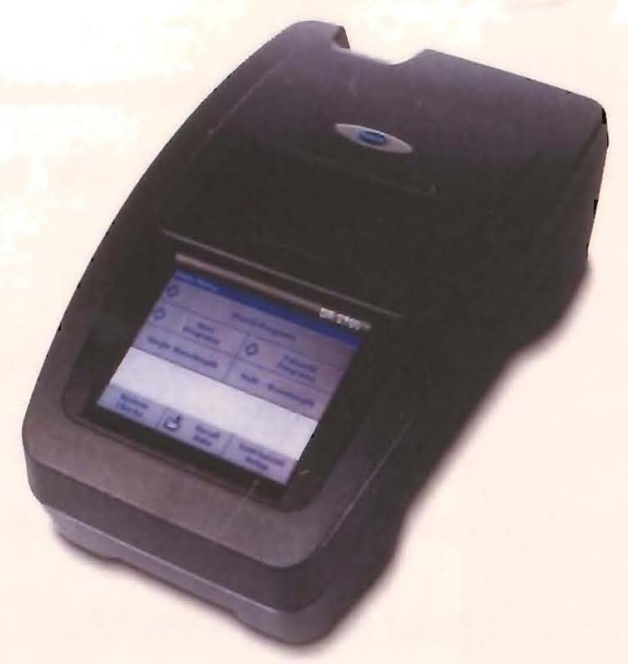

Figure 6.11 DR 2700 spectrophotometer

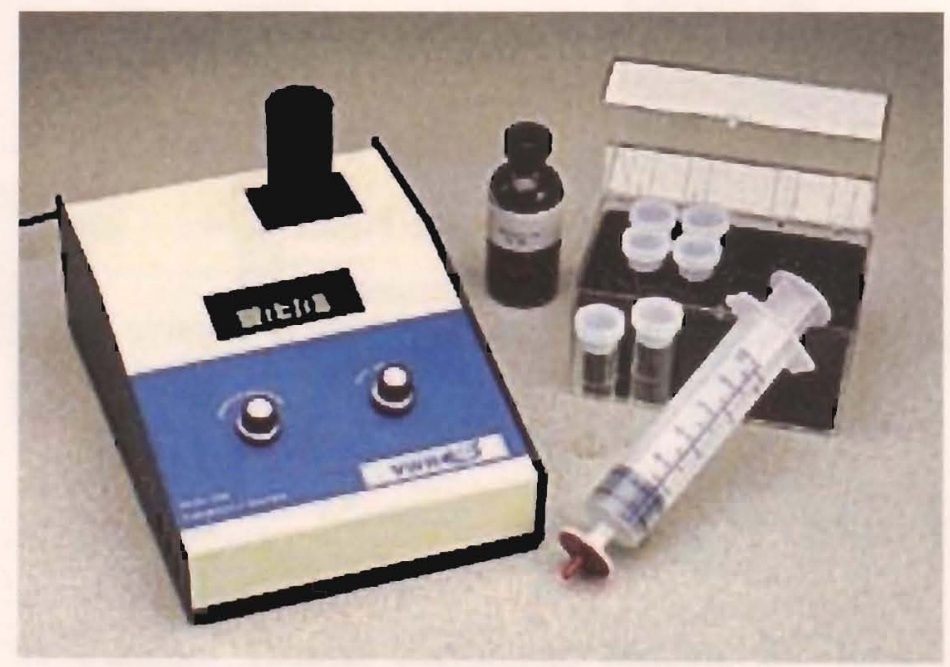

Figure 6.12 VWR ${ }^{\circledR}$ Model 800 Turbidity Meter 

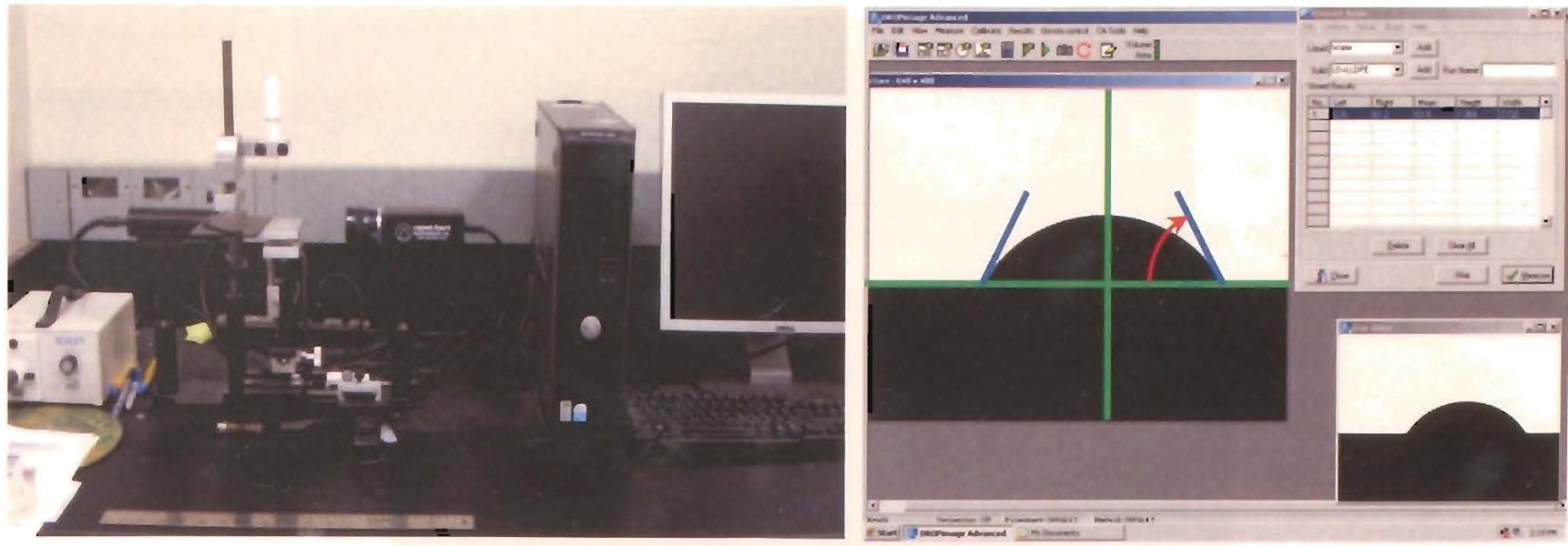

Figure 6.13 Rame-Hart Instrument goniometer for contact angle analysis (left) and the computer program output display (right), where the angle is indicated by the red arrow.

Contact angle of the membrane was measured by a goniometer, Rame Hart, Model 100.00115 , Figure 6.12. The goniometer is equipped with the Dropimage program (software) that calculates the value of contact angle as per picture image of the drop. A piece of the membrane was put on the sample holder, where a drop of water ( 3 microlitre) was placed on the membrane sample. At this moment a picture of the water drop in contact with the membrane surface was taken by high resolution camera. Picture image (Figure 6.12 picture on the right) revealed the static angle which was measured to be approximately $62^{\circ}$.

The scanning electron microscope (SEM) is an instrument used for the imaging and analysis of a wide range of materials of various applications and industries. SEM is essentially a high magnification microscope that uses an energy electron beam which scans a particular sample. Images of three-dimensional appearances are captured at magnifications ranging from 10 to more than 500,000 times (or 250 times the magnification of an optical microscope). High-resolution SEM images can reveal details of even less than 1 to $5 \mathrm{~nm}$ in size.

Energy dispersive spectroscopy (EDS) is a procedure used to identify and quantify the elemental composition of a sample area. EDS detects and separates characteristic $\mathrm{x}$-rays of different elements into an energy spectrum which is analyzed to determine the abundance of specific elements. EDS produces two-dimensional elemental mapping of materials/samples as small as a few micrometers. Typically EDS detectors are integrated into SEM or other instruments. 


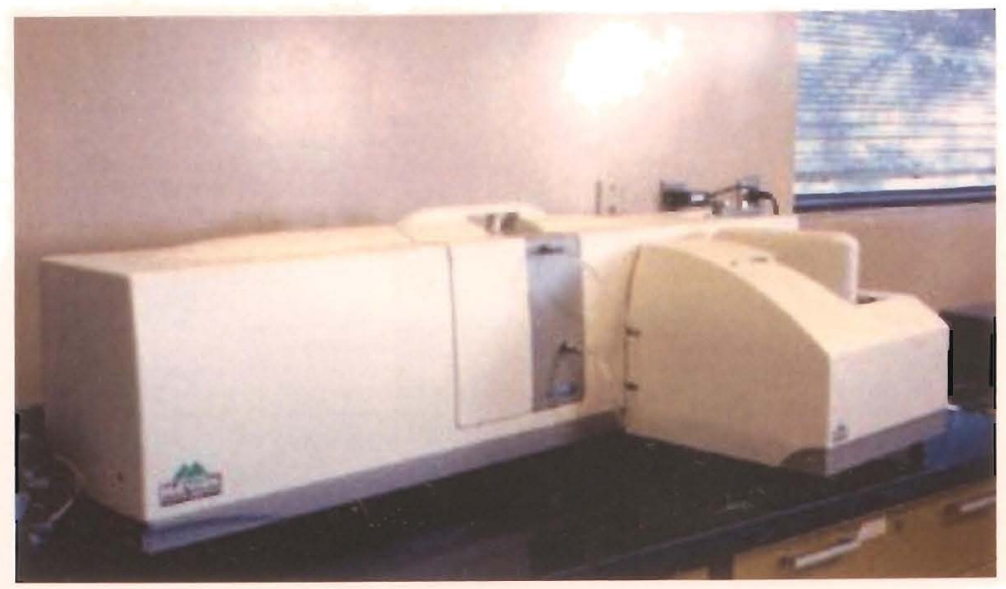

Figure 6.14 Malvern Mastersizer 2000 particle size analyzer

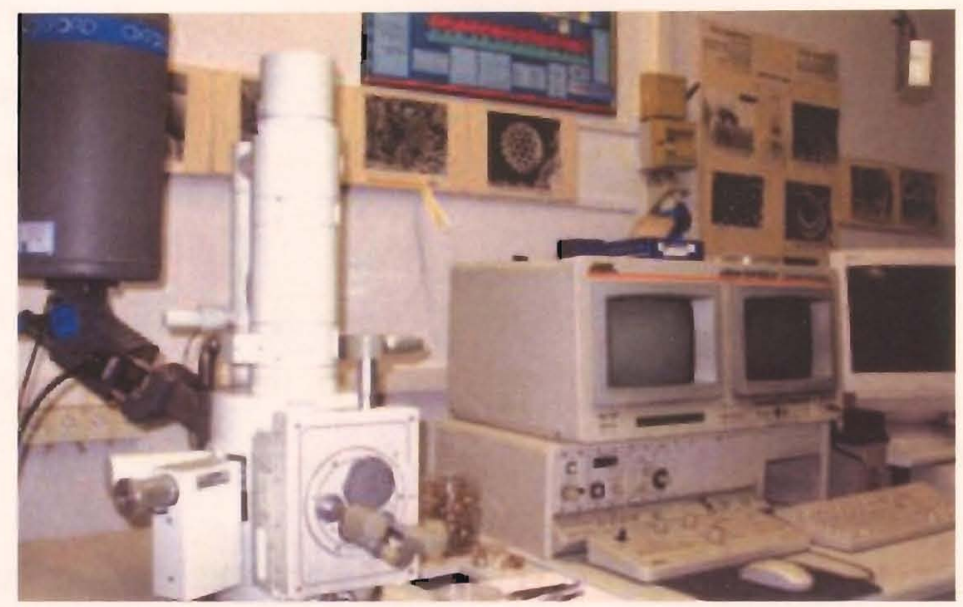

Figure 6.15 SEM and EDS analyzer equipment

Most studies use this technology to analyze fouling of membranes. Such analytical methods have been around and standardized better than some other methods producing both qualitative and quantitative analysis.

The SEM/EDS equipment used in this study was provided by the Mechanical Engineering department at Ryerson University. SEM/EDS analysis of the solid ceramic membrane was taken at various life times of the membrane.

a) when the membrane was dry,

b) after a wet flux test and then dried,

c) after filtration separation of the sample feed solution and then dried. 
The sample was cut lengthwise to approximately $10 \mathrm{~cm}$ to fit onto the insert-plate of the SEM and to obtain images of the cross-sectional area, see Figure 6.16. Initial images revealed that due to the very small pore structure of the membrane, a layer of gold coating had to be deposited onto the broken pieces for higher quality images. Figure 6.17 shows the cross section of the membrane and support at (a) 100 times magnification and (b) 2,000 times magnification.

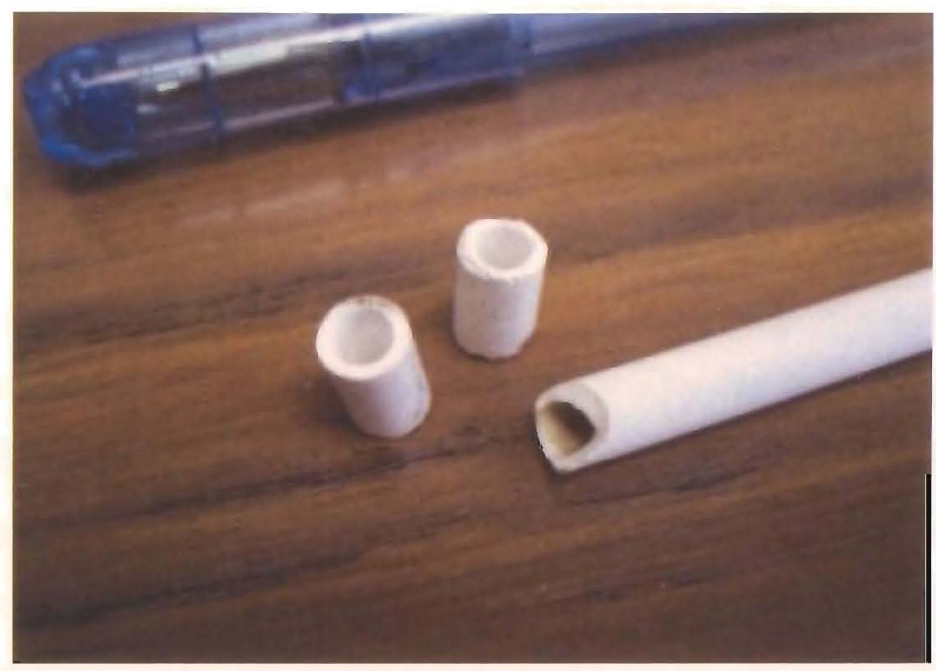

Figure 6.16 Photo of the ceramic broken pieces used to fit into the SEM imaging analyzer.

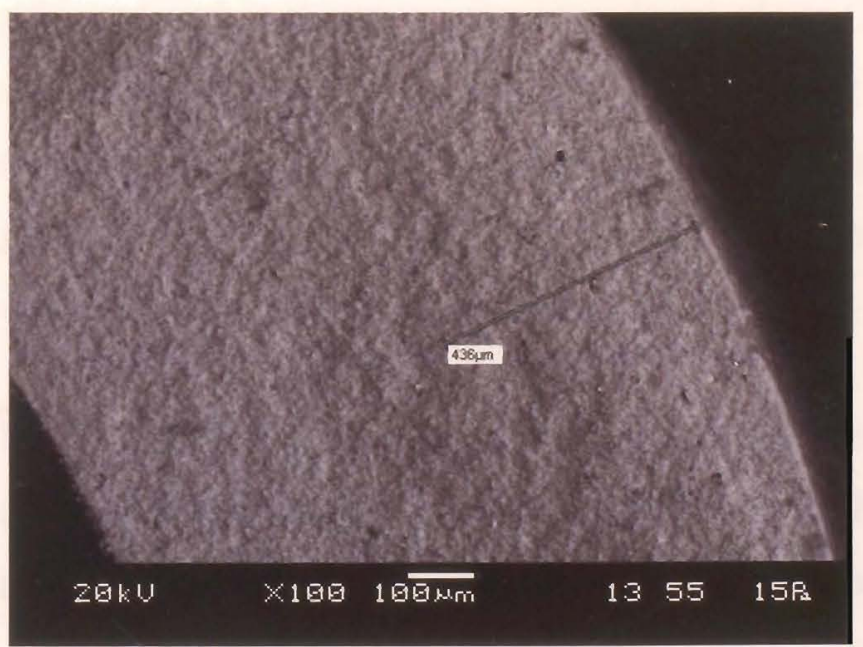

(a)

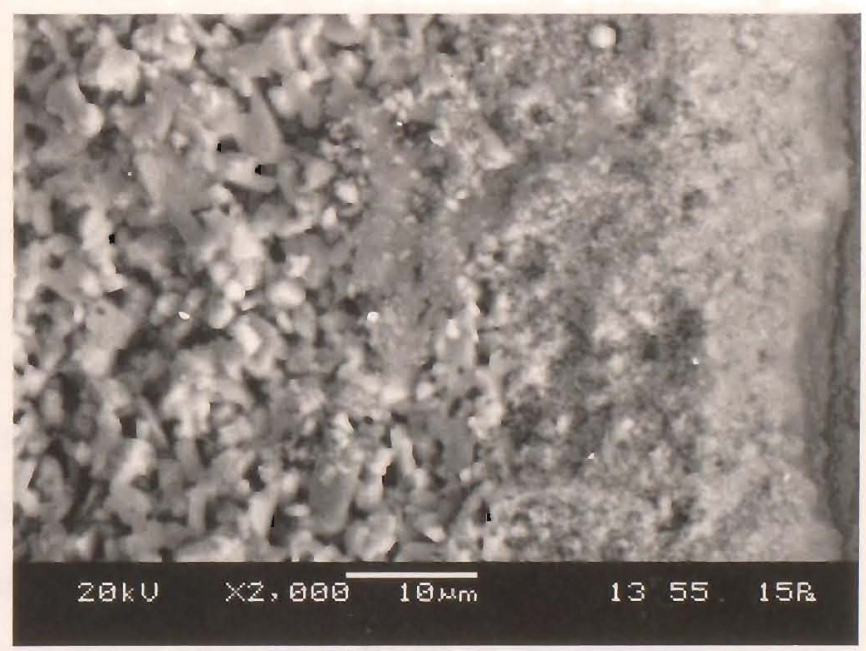

(b)

Figure 6.17 SEM image of the ceramic membrane piece showing the cross-section (a) at 100 magnification and, (b) 2,000 magnification. 


\subsection{EXPERIMENTAL RESULTS AND DISCUSSION}

This chapter presents the experimental results achieved with the ceramic membrane apparatus designed and built in this study. As it was mentioned in the previous chapter, the apparatus was first operated with water to examine operating conditions of the facility and to verify the manufacturer's specifications. This was the start-up of operations for the unit.

\subsection{Water Flux Tests}

The results here derive from Section 6.2.1 the Pure Water Flux Test method. For different feed flow rates and transmembrane pressures, the membrane permeability for pure water flux was tested and compared to the specifications of the manufacturer's values (given in Chapter 6, Table 6.5). The specifications are graphically shown in Figure 7.1 which plots steady-state permeate flux versus the applied pressure in cross-flow mode operation. From the figure, the manufacturer's flux performance of the ceramic membranes is depicted by the green shaded area. This region is bound by the maximum and minimum flux attainable at the corresponding pressure. Based on the design and build of the apparatus used in this experiment, higher pure water flux versus pressure was achieved and is shown by the blue diamonds in the figure. Since the data exceeded the supplier's specifications, it reveals that the set-up of the apparatus built here is suitable and that the manufacturer provides very conservative specifications. From Equation 3.4, rearranging the terms for total resistance, $R_{t o t}$, it was found to have an average of $1.34 \times 10^{12} \mathrm{~m}^{-1}$. In this case, since water was used as the fluid, $R_{t o t}$ is equal to the resistance of the membrane, $R_{m}$.

Based on the results obtained from membrane permeability experiments, the operating conditions (such as feed flowrate and applied pressure) to achieve specific fluxes by the apparatus were easily recognized. It was beneficial to evaluate membrane permeability at various TMP to determine appropriate settings of the operation, including pump speed and the position of the retentate valves which was a means to control the constant pressure of the feed side. 


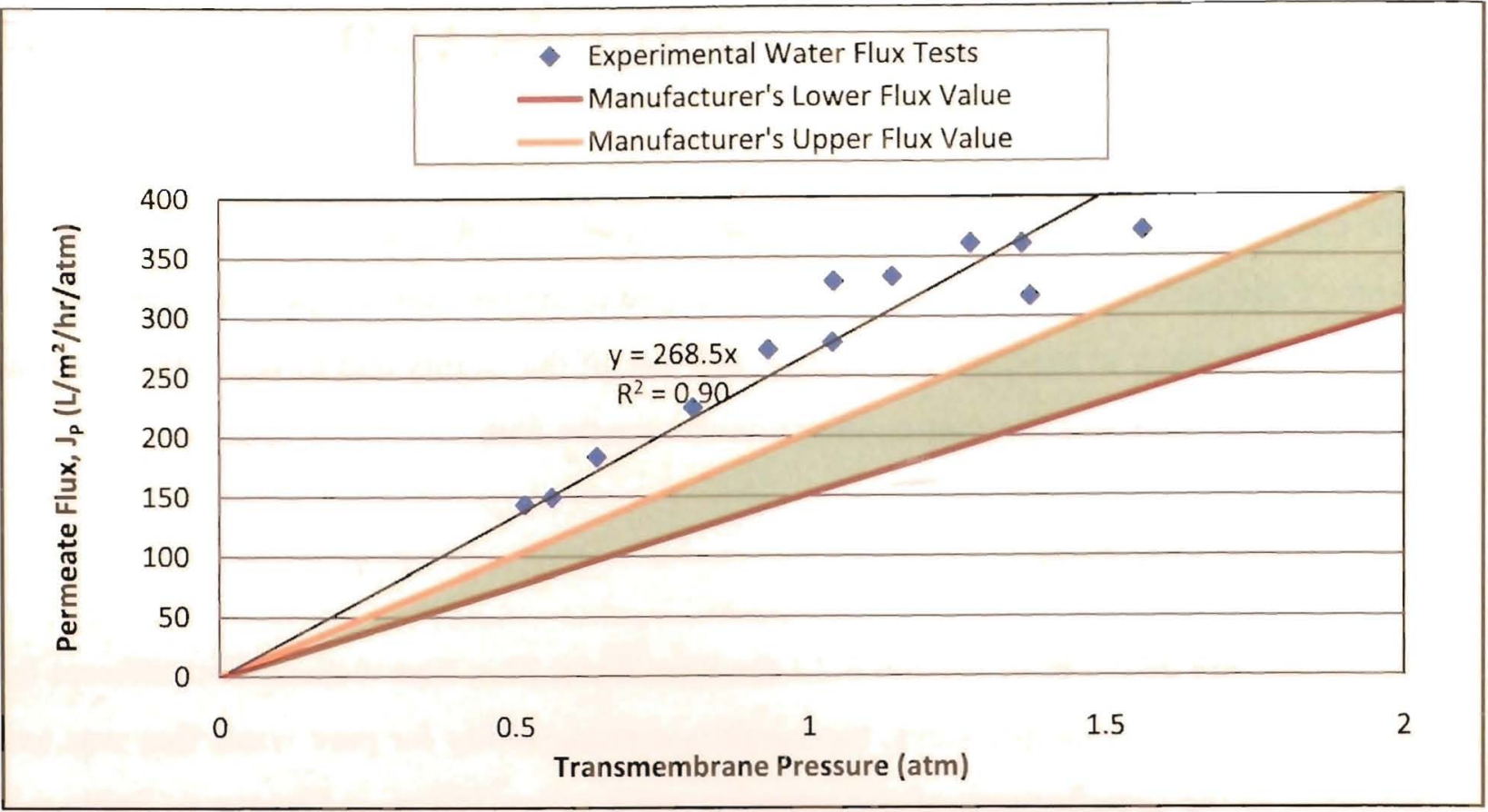

Figure 7.1 Graphical comparison of the experimental and manufacturer membrane water fluxes. Minimum and maximum flux attainable provided by the supplier 151.99 to 202.65 L/hour/squared meter.

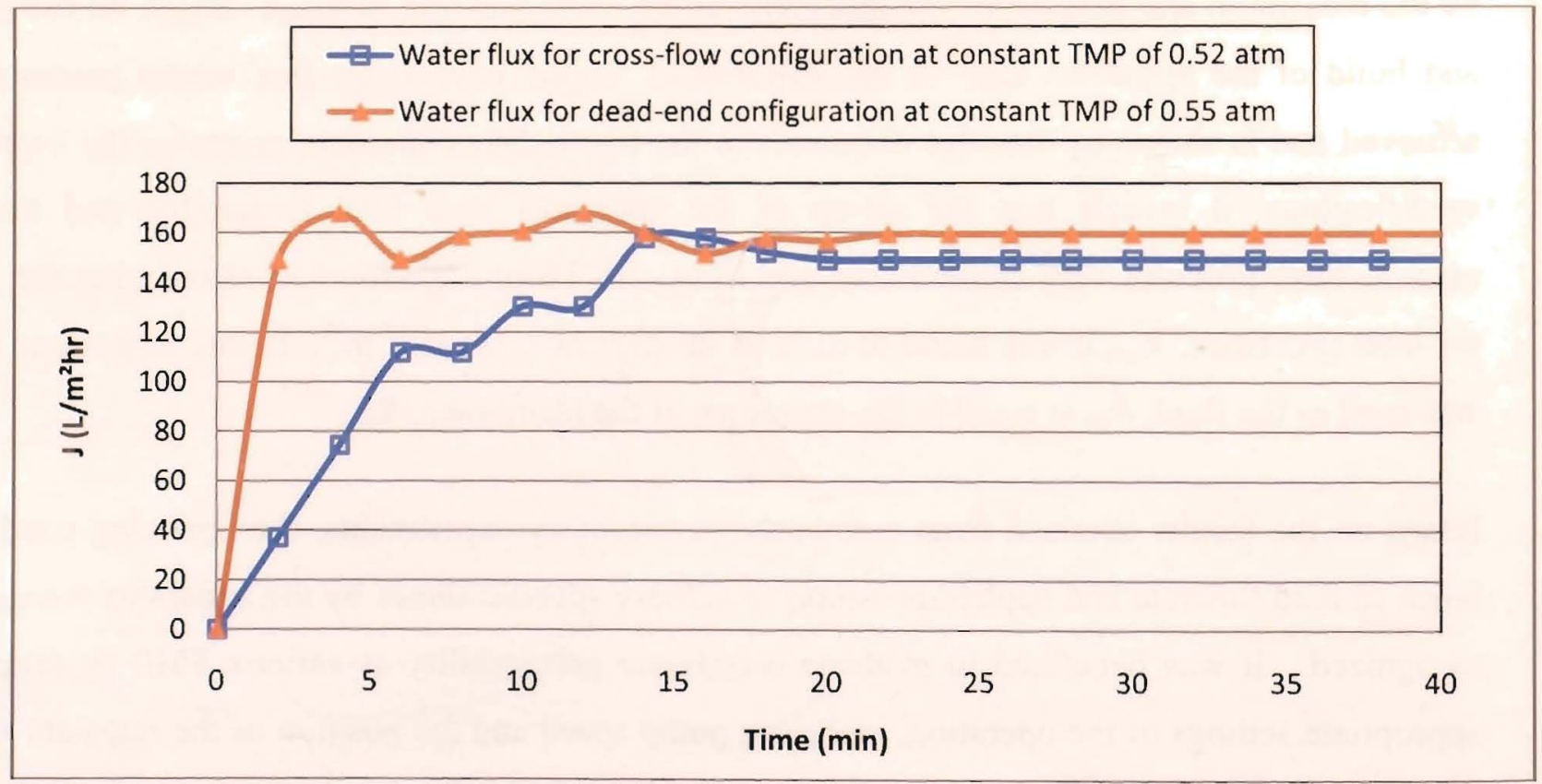

Figure 7.2 Results of water filtration in cross-flow and dead-end mode of operation, with applied pressures at about $0.52 \mathrm{~atm}$ and $0.55 \mathrm{~atm}$, respectively, and both with constant feed flowrates of $1.5 \mathrm{~L} / \mathrm{hr}$. 
Further from the data provided by the supplier, it was not stated whether the specifications were for cross-flow or dead-end mode of operation. Therefore, it was essential to check that the same results were attainable by the dead-end mode and this would verify the permeate flux versus TMP across the membrane from the feed side to the permeate side. Figure 7.2 displays the results obtained from this trial. Initially for dead-end configuration, the flux reaches steady state more quickly than for cross-flow configuration, since the build-up of pressure is required for cross-flow along the feed side to the retentate outlet. Based on the fluxes reached over the filtration time, the fluxes were 159.2 L/hr $\cdot \mathrm{m}^{2}$ for dead-end and $148.13 \mathrm{~L} / \mathrm{hr} \cdot \mathrm{m}^{2}$ for cross-flow mode, giving a percent difference of about $9.3 \%$. Also, based on the applied pressure or TMP which were 0.55 atm for dead-end and 0.52 atm for cross-flow, a percent difference of about $9.4 \%$ was found. Since the membrane permeability $P$ relates the direct proportionality of permeate flux $J$ and TMP $\Delta P$ (Darcy's law), given as $J=P \times$ $\Delta P$ (Peinemann, 2010), the two modes of operation achieved the same results. Therefore, this verified the supplier's specifications of permeate flux versus TMP across the membrane thickness from the feed side to the permeate side.

\subsection{Membrane Filtration of the Aqueous Solution}

Next, it was necessary to observe how the apparatus and membranes responded to a feed solution with solids. Therefore, the simple aqueous feed solution was made-up (Section 6.1.3) for this purpose and the experimental method of Section 6.2 .2 was performed.

Based on the matrix for the experimental runs (Table 6.6), analysis of each run was carried out. A water flux test was carried out for each new run since each run consisted of installing unused membranes. Figure 7.3 graphically displays one of the trials showing the water flux test and the aqueous feed solution run of the same membrane. For both liquids a constant feed flowrate $\left(Q_{f}\right)$ of about $2.1 \mathrm{~L} / \mathrm{hr}$ was operated at about the same applied pressure $(P)$. The water flux after a short time of 15 minutes was shown to become steady at approximately $227 \mathrm{~L} / \mathrm{hr} \cdot \mathrm{m}^{2}$ at $0.77 \mathrm{~atm}$.

For the filtration of the aqueous feed containing precipitate solids, it is seen in the figure that initially the flux increased to about $276 \mathrm{~L} / \mathrm{hr} \cdot \mathrm{m}^{2}$ during the first 10 minutes of the filtration then quickly dropped below that of the steady water feed flux after another 10 minutes. The drop in flux for that period is due to the concentration polarization or initial cake build-up, where the filtration is 
in deposition mode (Song et al., 1998). This is evaluated by the volumetric concentration factor, VCF (Equation 3.6),

$$
V C F=\frac{C_{M}}{C_{F}}
$$

where $V C F=$ volumetric concentration factor (dimensionless)

$C_{M}=$ concentration of suspended solids maintained on the feed side of the membrane (number or mass / volume)

$C_{F}=$ concentration of suspended in the influent feed water to the membrane unit (number or mass / volume)

For the initial 10 minutes of the filtration with with the aqueous feed solution, the VCF was calculated to be 0.3 , with the feed total suspended solids (TSS) concentration of about $20 \mathrm{mg} / \mathrm{L}$ and a retentate sample collected of $6 \mathrm{mgTSS} / \mathrm{L}$. The lower VCF may be due to the fact that the feed solution entering the membrane unit from the influent feed tank was not sufficiently mixed (i.e., feed solution suspended solids was not homogenous throughout the feed tank. Therefore, during the initial start of filtration, a lower retentate concentration of TSS would produce higher permeate flux since there is less fouling. After 10 minutes the flux started to drop to about $227 \mathrm{~L} / \mathrm{hr}^{2} \mathrm{~m}^{2}$, that of the water flux. The retentate sample TSS concentration was $47 \mathrm{mgTSS} / \mathrm{L}$, giving a VCF value of 2.35 . A further reduction in flux to about $168 \mathrm{~L} / \mathrm{hr} \cdot \mathrm{m}^{2}$ was observed after 20 minutes with a retentate concentration of $73 \mathrm{mgTSS} / \mathrm{L}$ and a VCF of 3.65 .

The VCF value less than 1 at the beginning of the filtration explains the concentration polarization (CP) or the start of pore blocking which will initiate CP. The increase in VCF values of 2.35 and 3.65 over time explains the crossflow mode of operation and the expected slower decrease of flux over time.

Similarly, testing at different feed flow rates and pressures, based on the experimental matrix were completed in this manner. The data (as well as the repeated trials) were further graphically plotted for flux over time based on; the feed various feed concentrations $\left(\mathrm{C}_{f}\right)$, Figure 7.4 (a) $20 \mathrm{mgTSS} / \mathrm{L}$, (b) $50 \mathrm{mgTSS} / \mathrm{L}$ and (c) $100 \mathrm{mgTSS} / \mathrm{L}$ and on the feed flow rates $\left(Q_{f}\right)$ Figure 7.5 (a) $1.5 \mathrm{~L} / \mathrm{hr}$, (b) $2.1 \mathrm{~L} / \mathrm{hr}$, (c) $2.7 \mathrm{~L} / \mathrm{hr}$ and (d) $3.3 \mathrm{~L} / \mathrm{hr}$. All results of the TSS analysis for the produced permeate showed no values higher than $2 \mathrm{mgTSS} / \mathrm{L}$ at the different operating conditions. 
This set of experiments (that is, of applying the various feed flowrates and feed concentrations) was helpful to observe the response of the apparatus at different conditions.

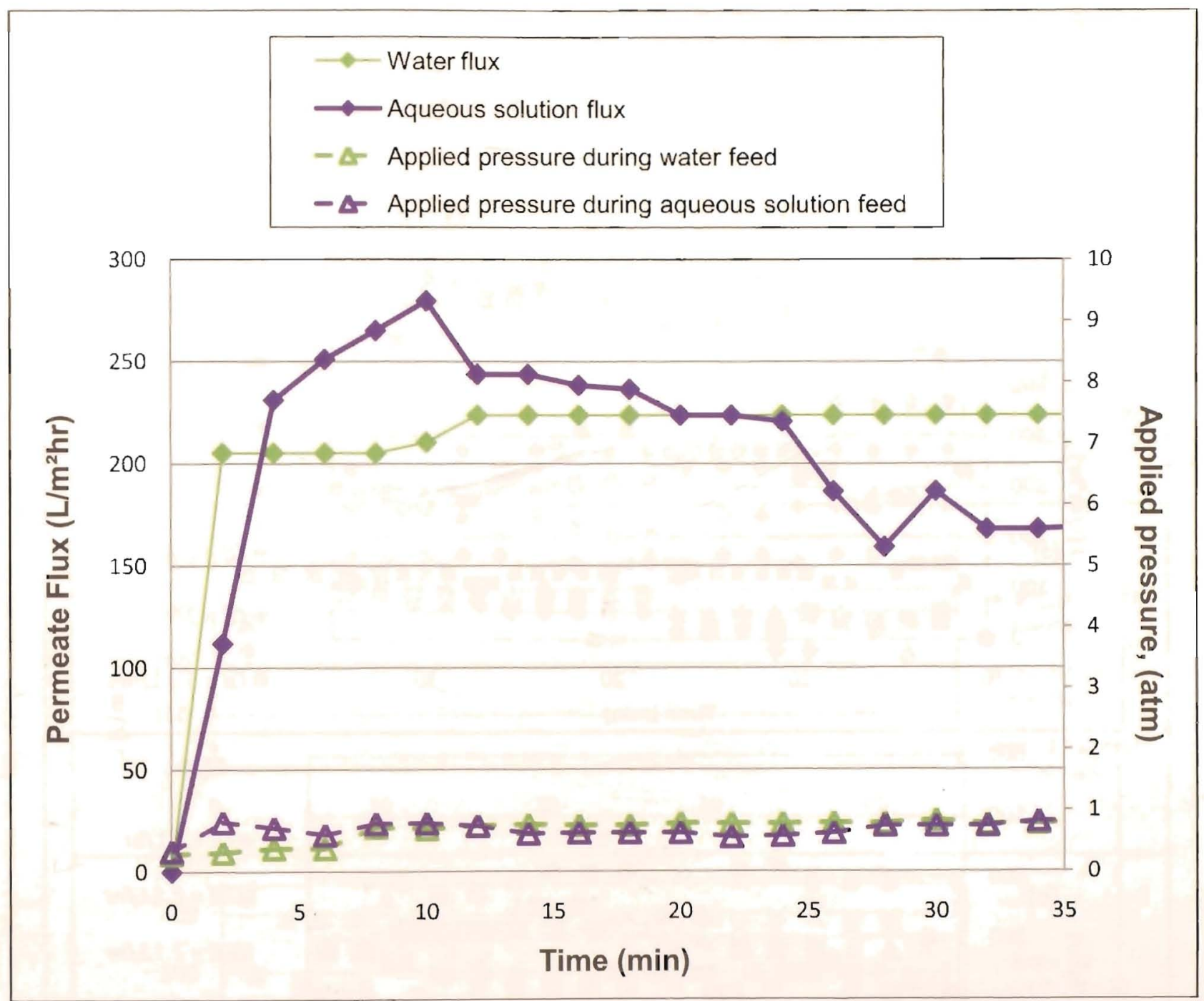

Figure 7.3 Graph of a water flux test and filtration of the aqueous feed solution for the same membrane run with feed solution at constant TSS concentration of about $20 \mathrm{mg} / \mathrm{L}$ (Run 2). 


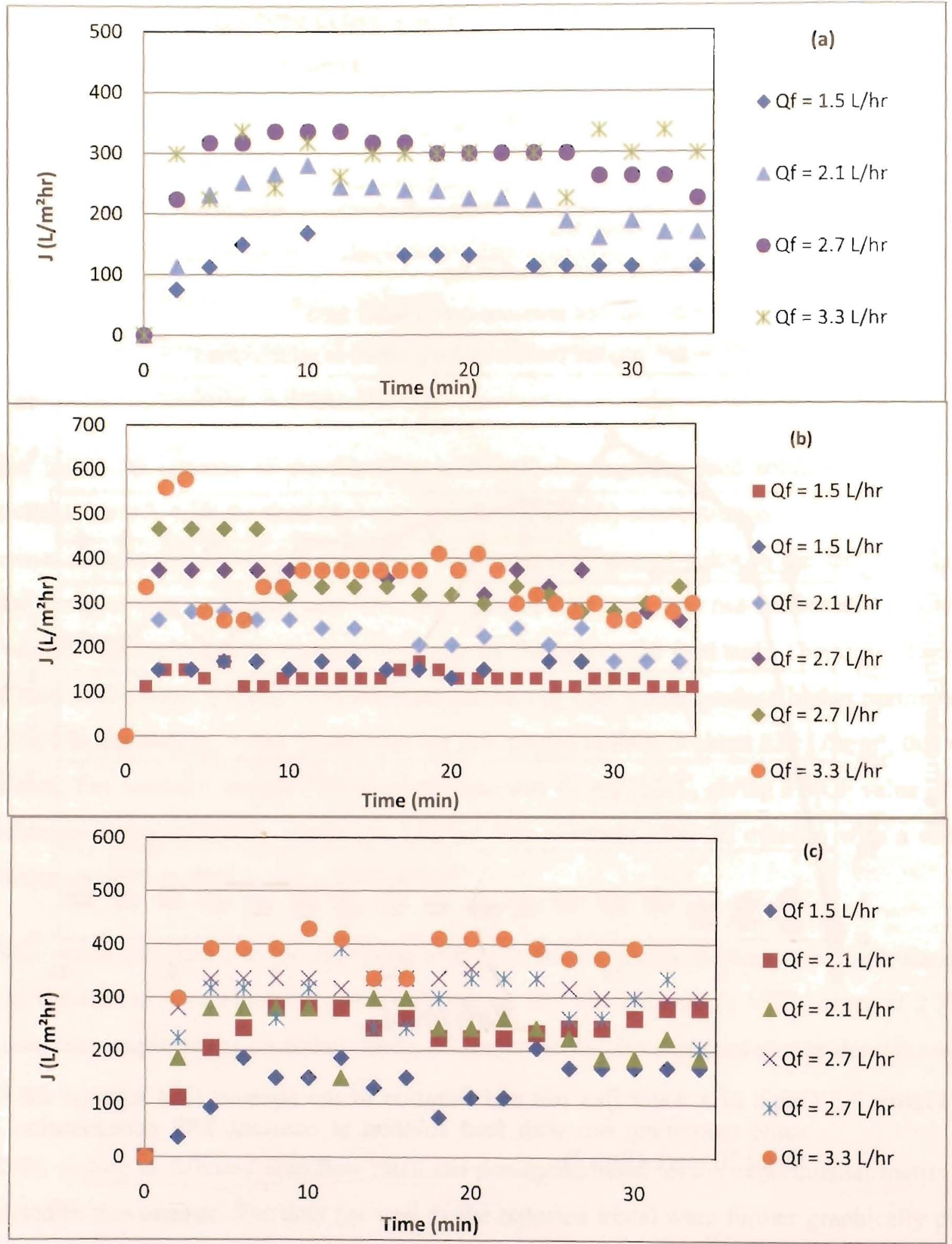

Figure 7.4 Graphical analysis of the aqueous solution flux over time (included are the repeats). Each graph represents one constant feed concentration $\left(C_{f}\right)$ and varying feed flow rates $\left(Q_{f}\right)$ and pressures $(P)$ determined during operation of the apparatus. 


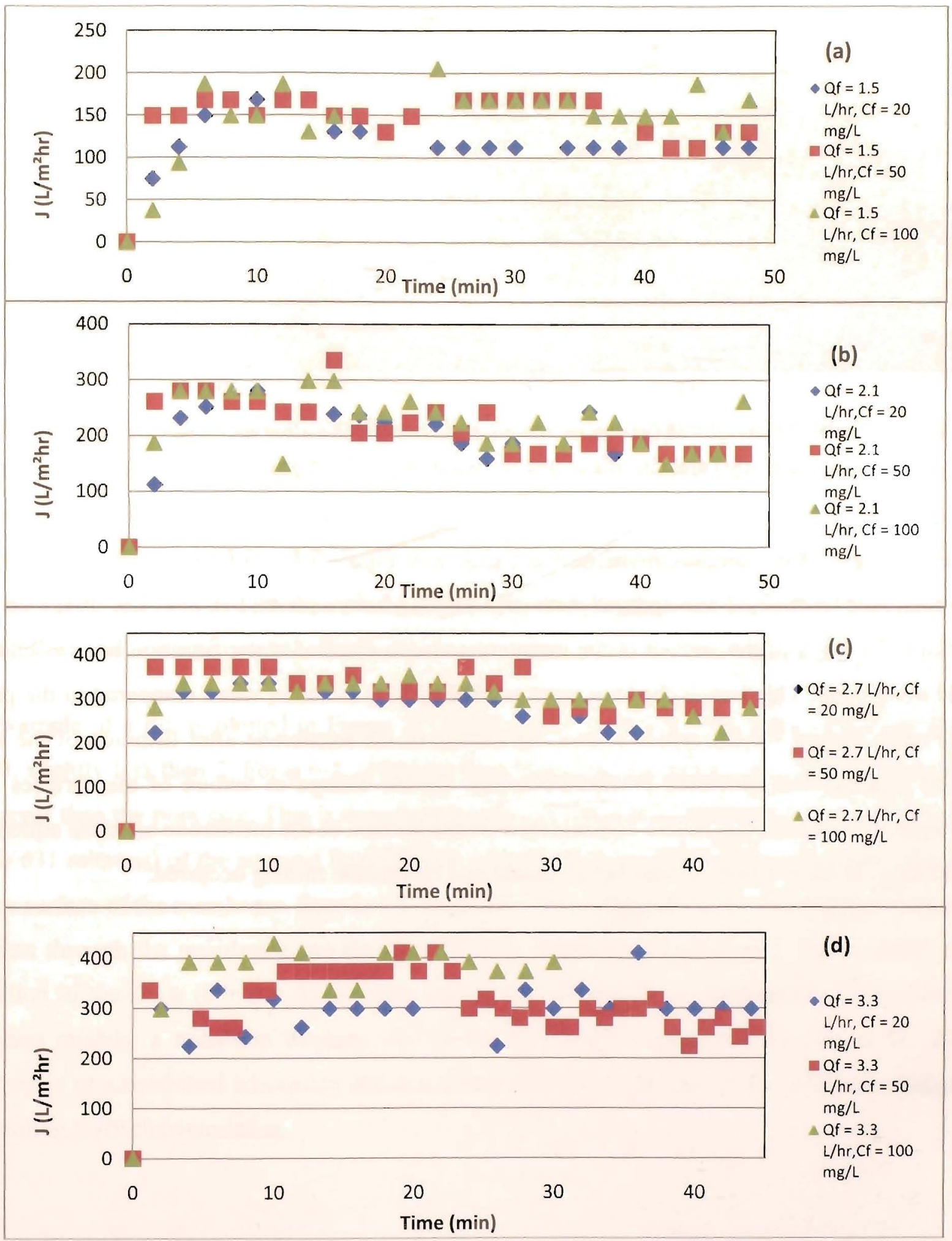

Figure 7.5 Graphical analysis of the aqueous solution for various feed concentrations (included are the repeats). Each graph represents one constant feed flow rate $\left(Q_{f}\right)$ at three different TSS feed concentrations $\left(C_{f}\right)$ of approximately $20 \mathrm{mg} / \mathrm{L}$ (blue), $50 \mathrm{mg} / \mathrm{L}$ (red) and $100 \mathrm{mg} / \mathrm{L}$ (green). 


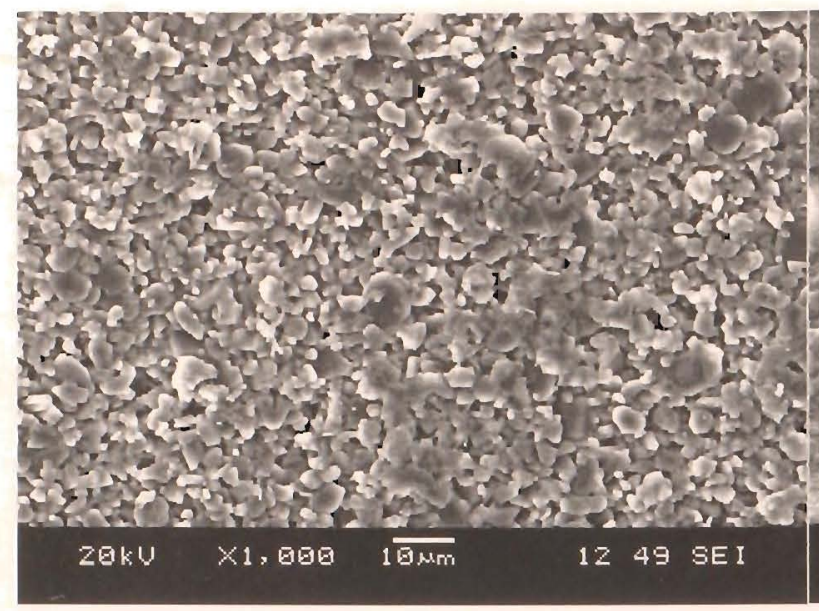

(a)

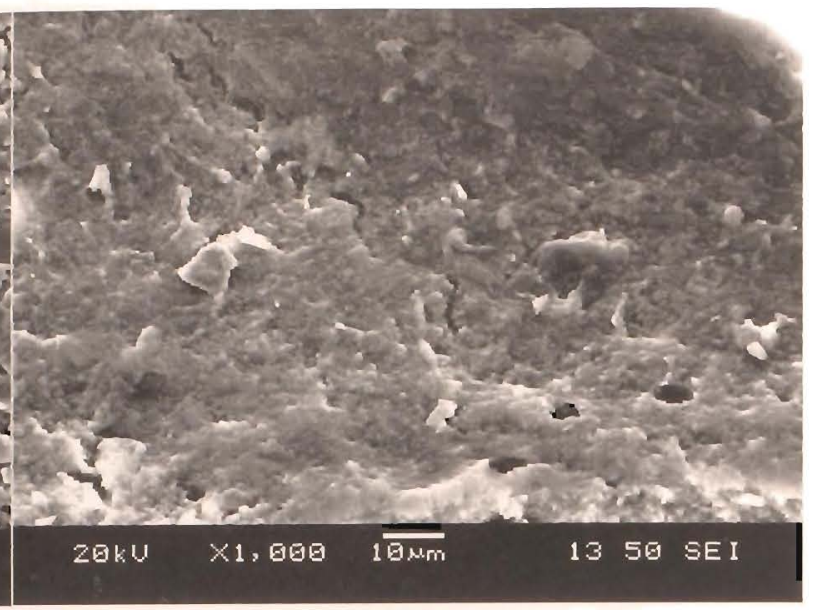

(b)

Figure 7.6 SEM images of (a) sample of ceramic membrane after distilled water filtration (with Au coating) and (b) after aqueous solution feed filtration (with Au coating)

SEM images of the ceramic membrane are shown in Figure 7.6 at 1,000 times magnification. The membranes were dried and sprayed with gold coating before photo analysis. The image on the left Figure 7.6 (a) is of the surface of the membrane after a distilled water filtration has passed through the membrane. This image shows a more porous surface structure when compared to the photo on the right, Figure 7.6 (b), which shows the surface of the membrane after filtration of the aqueous feed solution that contained precipitate solids. By the change in texture of the surfaces in both images, it is visible that solute concentrated on the surface of the membrane after the aqueous feed filtration. In other words, a cake layer formed and membrane fouling occurred. 
For constant pressure filtration, the Hermia model, given in Equation 5.8, represents the resistance (inverse flux, $d t / d V$ ) related to the change in resistance $\left(d^{2} t / d V^{2}\right)$ or also known as the resistance coefficient (Hermia, 1982). The fouling model

$$
\frac{d^{2} t}{d V^{2}}=\beta\left(\frac{d t}{d V}\right)^{\varphi}
$$

where $t=$ time (s)

$V=$ cumulative volume of filtrate (L)

$\beta=$ blocking law filtration coefficient

$\varphi=$ blocking law filtration exponent, unitless

was applied to the data obtained from the experimental matrix. Equation 5.8 was linearized using a spreadsheet to graphically obtain the parameter $\varphi$, which is an index to the nature of fouling (defined for each filtration law in Table 5.3). The values of $\varphi$ and the operating feed conditions of each run are shown in Table 7.1. From this table, it is generally shown that at constant feed flowrates with increase of TSS feed concentrations, the values of $\varphi$ decrease. In addition, increases in feed flow rate at a constant TSS feed concentration, also results in a decrease of $\varphi$.

An example of a run is plotted in Figure 7.7 for the Run number 2. The calculated value of $\varphi$ is 1.910 , slightly less than 2 . For $\varphi=2$, complete pore blocking, the main aspect is that the particles are larger than the pore size. This is described by the particle size distribution (given previously as 1.9 to 631 microns) of the aqueous feed solution which had large particles that formed a cake layer on the surface of the membrane. Based on Peinemann, 2010, when $\varphi \neq 2$ the influence of fouling on the flux through the membrane can be demonstrated. When a plot of $d^{2} t / d V^{2}$ versus $d t / d V$ yields deviation in the slope $(0>\varphi>2)$ probable causes may be due to: a combination of the blocking filtration models; a transition between two of the blocking filtration models (Ho et al., 2000); occurrence of a combined adsorption and desorption of foulants (Kumar et al., 2008); or changes in the fouling layer characteristics. 
Table 7.1 Hermia model results of $\varphi$ (describes type of fouling, see Table 5.3) for the aqueous feed solution filtration. Comparison of the varied feed flow rates and TSS feed concentration

\begin{tabular}{|c|c|c|c|}
\hline $\begin{array}{l}\text { Run } \\
\text { Number }\end{array}$ & $\begin{array}{l}\text { Feed Flow Rate } \\
\text { (Lhr) }\end{array}$ & $\begin{array}{c}\text { Feed TSS } \\
\text { Concentration } \\
\text { (mg/L) }\end{array}$ & Calculated Parameter $\varphi$ \\
\hline 1 & 1.5 & 20 & 2.330 \\
\hline 2 & 2.1 & 20 & 1.910 \\
\hline 3 & 2.7 & 20 & 0.757 \\
\hline 4 & 3.3 & 20 & 0.642 \\
\hline 5 & 1.5 & 50 & 1.779 \\
\hline 5 & 1.5 & 50 & 1.470 \\
\hline 6 & 2.1 & 50 & 1.233 \\
\hline 7 & 2.7 & 50 & 0.719 \\
\hline 7 & 2.7 & 50 & 0.450 \\
\hline 8 & 3.3 & 50 & 0.407 \\
\hline 9 & 1.5 & 100 & 1.554 \\
\hline 10 & 2.1 & 100 & 1.110 \\
\hline 10 & 2.1 & 100 & 1.118 \\
\hline 11 & 2.7 & 100 & 0.296 \\
\hline 11 & 2.7 & 100 & 0.294 \\
\hline 12 & 3.3 & 100 & -0.282 \\
\hline
\end{tabular}

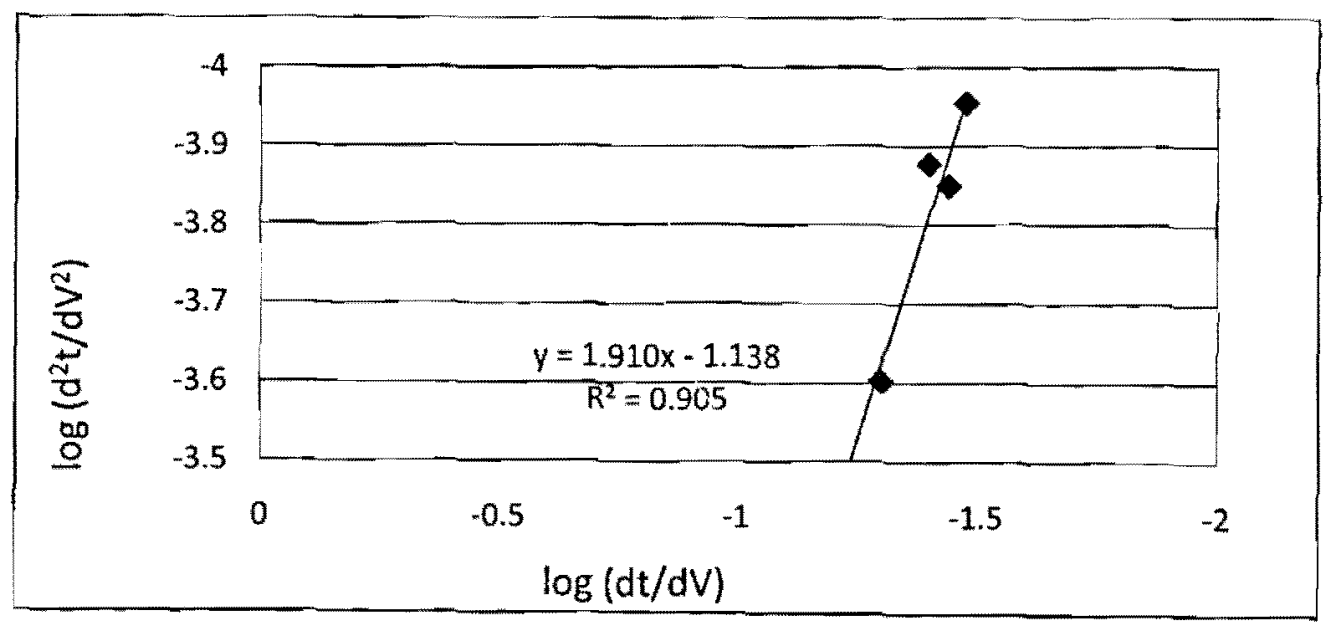

Figure 7.7 Graphical plot of the linearized Hermia model applied to Run number 2 (at a feed flowrate of $2.1 \mathrm{~L} / \mathrm{hr}$, a TSS feed concentration of approximately $20 \mathrm{mg} / \mathrm{L}$ and a constant applied pressure of $0.563 \mathrm{~atm}$, for the time, $8 \leq \mathrm{t} \leq 28$ minutes, see Figure 7.3 ) 


\subsection{Filtration of the Aqueous Solution with Membrane Cleaning}

After the single runs pertaining to the experimental matrix, correlating different feed flow rates and feed suspended solids concentration (Table 6.6), were completed, trials which included cleaning while using the same aqueous feed was performed (experimental method Section 6.2.3). A graphical analysis for one of the experimental results is shown in Figure 7.8. In this filtration experiment two different cleaning methods were performed; first trial using water backwashing ( $C$ and $F$ ) and second by CEB using hydrochloric acid (H). An initial water flux test (A) before the start of the filtration, and after each cleaning (D, G and I), were done to determine the efficiency of the cleaning. Table 7.2 shows the results obtained from Figure 7.8 .

Table 7.2 Collected data from the experimental trial of aqueous solution feed with cleaning.

\begin{tabular}{|c|c|c|c|c|c|}
\hline $\begin{array}{c}\text { Mode of Operation } \\
\text { and Feed }\end{array}$ & $\begin{array}{l}\text { Approximate } \\
\text { Time (min) }\end{array}$ & $\underset{\left(L / h r \cdot m^{2}\right)}{\text { Flux }}$ & $\begin{array}{l}\text { Pressure } \\
\text { (atm) }\end{array}$ & $\begin{array}{l}\text { Total } \\
\text { Volume } \\
\text { Fed } \\
\text { (mL) }\end{array}$ & $\begin{array}{l}\text { Water Flux \% } \\
\text { recovered } \\
\text { (compared to } \\
\text { initial test) }\end{array}$ \\
\hline $\begin{array}{l}\text { (A) Initial Water Flux } \\
\text { Test }\end{array}$ & 60 & 106.21 & 0.97 & 1440 & - \\
\hline $\begin{array}{l}\text { (B) First Aqueous } \\
\text { Feed Filtration }\end{array}$ & 160 & $\begin{array}{l}\text { Start: } 113.48 \\
\text { end: } 83.07\end{array}$ & $\begin{array}{l}\text { Start: } 0.57 \\
\text { end: } 0.50\end{array}$ & 2520 & $\ldots$ \\
\hline $\begin{array}{l}\text { (C) First Cleaning, } \\
\text { Water }\end{array}$ & 20 & -- & 1.21 & 1200 & -- \\
\hline $\begin{array}{l}\text { (D) Second Water Flux } \\
\text { Test }\end{array}$ & 60 & 103.50 & 0.83 & 940 & 97.45 \\
\hline $\begin{array}{l}\text { (E) Second Aqueous } \\
\text { Feed Filtration }\end{array}$ & 160 & $\begin{array}{l}\text { Start: } 98.57 \\
\text { end: } 54.60\end{array}$ & $\begin{array}{ll}\text { Start: } & 1.22 \\
\text { end: } & 0.89\end{array}$ & 2615 & - \\
\hline $\begin{array}{l}\text { (F) Second Cleaning, } \\
\text { Water }\end{array}$ & 30 & -- & 1.2 & 1400 & -- \\
\hline $\begin{array}{l}\text { (G) Third Water Flux } \\
\text { Test }\end{array}$ & 60 & 81.62 & 0.71 & 660 & 76.85 \\
\hline $\begin{array}{l}\text { (H) Third Cleaning, } \\
\text { Hydrochloric Acid }\end{array}$ & 30 & $\cdots$ & 1.3 & 500 & $\cdots$ \\
\hline $\begin{array}{l}\text { (l) Final Water Flux } \\
\text { Test }\end{array}$ & 50 & 200.92 & 0.77 & 1230 & 189 \\
\hline
\end{tabular}




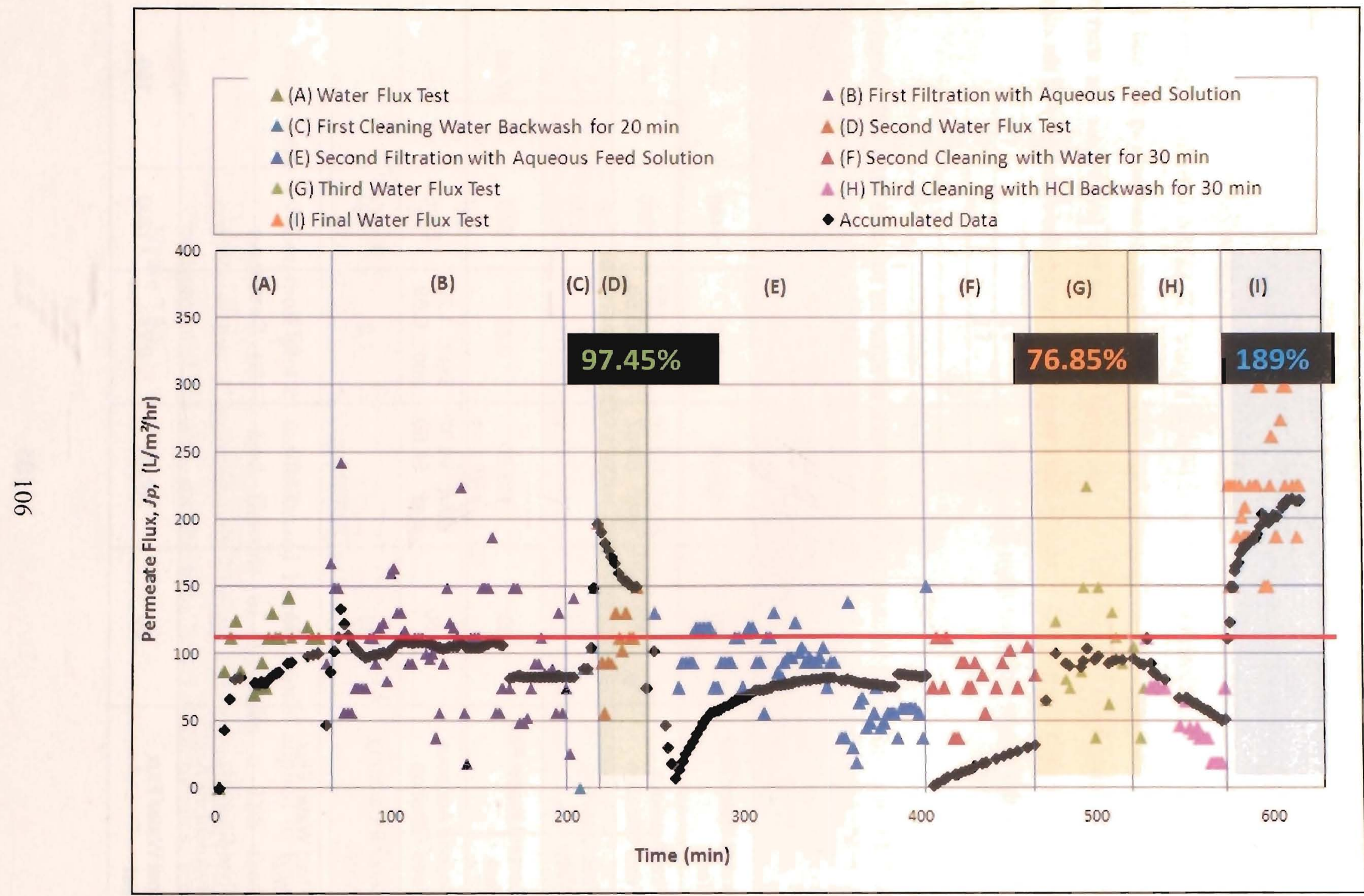

Figure 7.8 Graphical Analysis of the Aqueous Feed Filtration and Membrane Cleaning Intervals Plotting Flux versus Time at Constant Feed Flowrate of $1.5 \mathrm{l} / \mathrm{hr}$ and average pressure of $0.92 \mathrm{~atm}$. 
The cleaning efficiency was evaluated in terms of the overall percent flux recovery. That is, the final water flux value divided by the initial water flux value. The results show about a $3 \%$ overall flux loss after the first cleaning of backwash and a $28 \%$ loss after the second cleaning, both by backwash. After the second cleaning the flux loss decreased by a significant amount, therefore trial to recover the flux by applying CEB was established. The cleaning agent used was hydrochloric acid with an $89 \%$ increase after the cleaning. $\mathrm{HCl}$ cleaning produced the best recovery percentage, as well as flux recovery. This was the observed result due to the fact that the feed solution was a composition of inorganic salts that were easily dissolved by the acid. The water backwash method was ineffective to clean the fouled membrane and may have only removed the solids in the pores during backwashing and not the attached particles on the surface the membrane. This analysis was helpful to first devise and develop how the cleaning protocol would be implemented before experimenting with the CUBEN effluent. 


\subsection{Filtration of CUBEN Feed with Membrane Cleaning}

The results of the CUBEN wastewater filtration, Section 6.2 .4 , are discussed here which incorporates the cleaning methods from Section 6.2.5, Table 6.7. The filtration was done at constant applied pressure average of $0.85 \mathrm{~atm}$. The TSS concentration of the feed wastewater varied throughout the filtration experiments from as high as $121 \mathrm{mg} / \mathrm{L}$ and as low as $12 \mathrm{mg} / \mathrm{L}$. However, the permeate effluent collected in every case resulted in a concentration of less than or equal to $3 \mathrm{mg} / \mathrm{L}$ and turbidities less than 1 NTU.

It was preferred to use the least amount of chemicals for the cleaning solutions to minimize the amount used and to observe the difference between the solutions. If the concentrations of the cleaning solutions were higher, then it may be possible that they all could be effective in cleaning the membranes and no difference would be observed. Therefore, the chemical solutions used in the cleaning methods all had a concentration of less than $1 \%$ weight.

The approach to the experimental run is depicted in Figure 7.9, in which the water flux tests, both initial and final, were operated for about one hour and the CUBEN effluent feed filtration ranged from three hours to one hour until a steady flux was attainable. The membrane cleaning intervals were 30 minutes for backwash and $\mathrm{CEB}$, and three hours for membrane soaking.

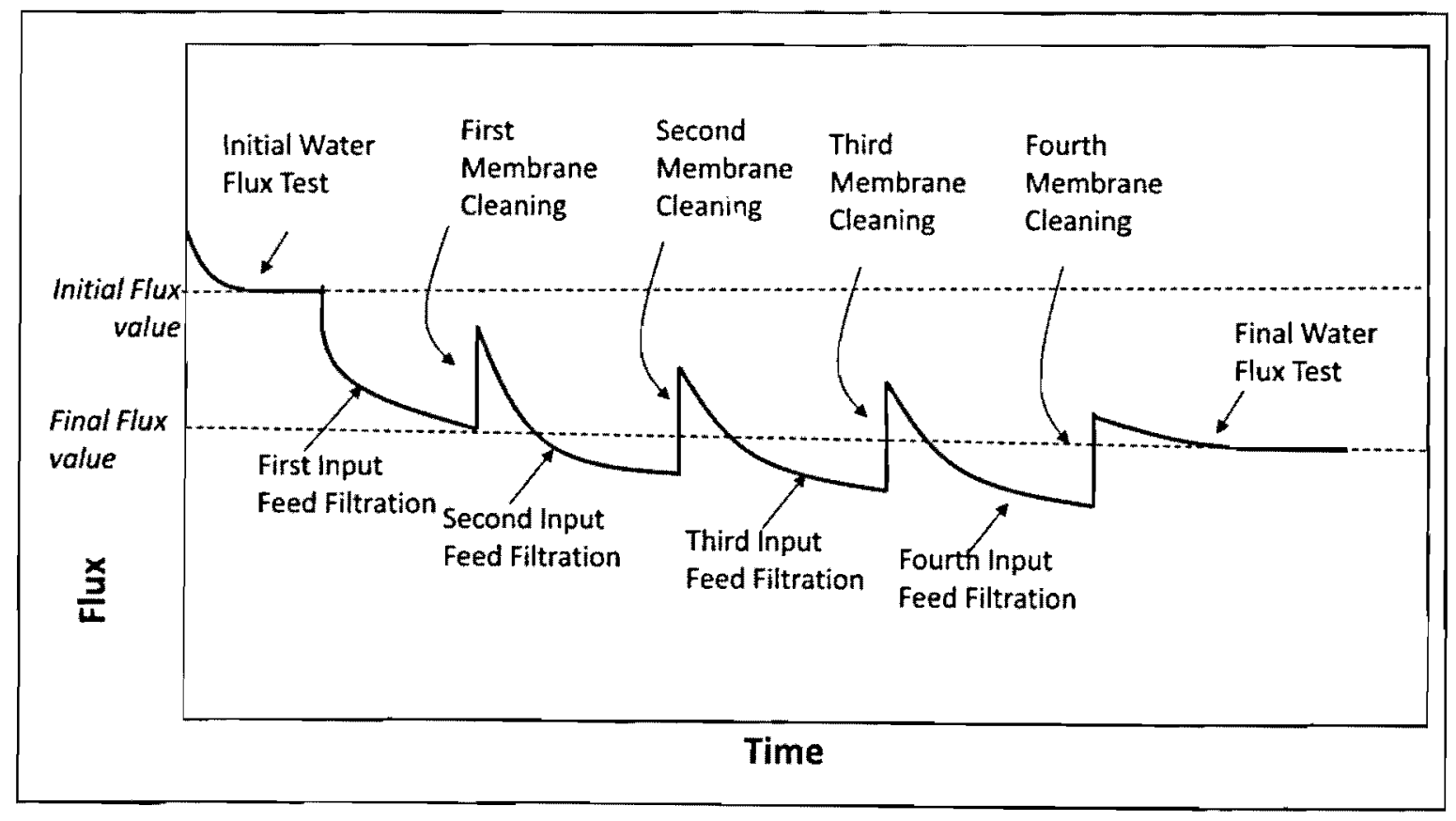

Figure 7.9 Conceptual approach to the filtration/fouling and cleaning intervals experiments. 
The evaluation of the cleaning efficiency was evaluated in terms of membrane permeability recovery using the overall percent flux recovery $(\%)=($ flux at final / flux at initial $) \times 100$.

For the backwash and the chemically enhanced backwash methods employed during the filtration of wastewater, the data collected is tabulated in Table 7.3. It is seen that the lowest overall recovery of flux, comparing the initial and final water flux, for the backwashing/CEB method was for both the distilled water and acetic acid solutions at an overall recovery of approximately $54.9 \%$ and $52.6 \%$, respectively. The highest overall flux recovery for a backwashing chemical solution was for the hydrochloric acid at $72.7 \%$. An example of one of the graphical plots for filtration of CUBEN effluent with CEB using sodium hydroxide backwashing intervals is shown in Figure 7.10.

Table 7.3 Tabulated data and flux recovery for membrane backwashing of various chemical solutions used

\begin{tabular}{|c|c|c|c|c|c|c|c|c|}
\hline & & $\begin{array}{c}\text { Water } \\
\text { Backwash } \\
\text { Trial } 1\end{array}$ & $\begin{array}{c}\text { Water } \\
\text { Backwash } \\
\text { Trial } 2\end{array}$ & $\begin{array}{c}\text { Acetic Acid } \\
\text { Backwash } \\
\text { Trial } 1\end{array}$ & $\begin{array}{c}\text { Acetic Acid } \\
\text { Backwash } \\
\text { Trial } 2\end{array}$ & $\begin{array}{c}\text { Hydrochloric } \\
\text { Acid } \\
\text { Backwash } \\
\text { Trial } 1 \\
\end{array}$ & $\begin{array}{l}\text { Hydrochloric } \\
\text { Acid } \\
\text { Backwash } \\
\text { Trial } 2 \\
\end{array}$ & $\begin{array}{l}\text { Sodium } \\
\text { Hydroxide } \\
\text { Backwash }\end{array}$ \\
\hline $\begin{array}{c}\text { Mode of } \\
\text { Operation and } \\
\text { Feed }\end{array}$ & $\begin{array}{c}\text { Approximate } \\
\text { Time (hr) }\end{array}$ & $\begin{array}{l}\text { Flux } \\
\left(\mathrm{L} / \mathrm{hr} \cdot \mathrm{m}^{2}\right)\end{array}$ & $\begin{array}{c}\text { Flux } \\
\left(\text { Lhr } r \mathrm{~m}^{2}\right)\end{array}$ & $\begin{array}{c}\text { Flux } \\
\left(\mathrm{L} / \mathrm{hr} \cdot \mathrm{m}^{2}\right)\end{array}$ & $\underset{\substack{\text { Flux } \\
\left(\mathrm{L} / \mathrm{hr} \cdot \mathrm{m}^{2}\right)}}{ }$ & $\begin{array}{c}\text { Flux } \\
\left(\mathrm{L} / \mathrm{hr} \cdot \mathrm{m}^{2}\right)\end{array}$ & $\begin{array}{c}\text { Flux } \\
\left(\text { L/hr } r \mathrm{~m}^{2}\right)\end{array}$ & $\begin{array}{c}\text { Flux } \\
\left(\mathrm{L} / \mathrm{hr} \cdot \mathrm{m}^{2}\right)\end{array}$ \\
\hline $\begin{array}{l}\text { Initial Water Flux } \\
\text { Test } \\
\end{array}$ & 1 & 122.15 & 136.8 & 121.53 & 124.51 & 123.16 & 120.83 & 146.08 \\
\hline $\begin{array}{l}\text { First Filtration } \\
\text { Interval }\end{array}$ & 3 & $\begin{array}{l}\text { start: } 67.60 \\
\text { end: } 34.97\end{array}$ & $\begin{array}{l}\text { star: } 65.27 \\
\text { end: } 39.63\end{array}$ & $\begin{array}{l}\text { start: } 18.65 \\
\text { end: } 15.54\end{array}$ & $\begin{array}{l}\text { start: } 29.10 \\
\text { end: } 17.10\end{array}$ & $\begin{array}{l}\text { start: } 22.25 \\
\text { end: } 12.04\end{array}$ & $\begin{array}{c}\text { start: } 23.74 \\
\text { end: } 13.2\end{array}$ & $\begin{array}{l}\text { start: } 83.14 \\
\text { end:25.64 }\end{array}$ \\
\hline First Cleaning, & 0.5 & - & $=$ & - & - & $\cdots$ & - & - \\
\hline $\begin{array}{l}\text { Second Filtration } \\
\text { Interval }\end{array}$ & 2 & $\begin{array}{l}\text { start: } 73.43 \\
\text { end: } 27.97\end{array}$ & $\begin{array}{l}\text { start: } 55.95 \\
\text { end: } 23.31\end{array}$ & $\begin{array}{l}\text { stant } 48.22 \\
\text { end } 23.98\end{array}$ & $\begin{array}{l}\text { start: } 52.48 \\
\text { end: } 26.64\end{array}$ & $\begin{array}{l}\text { start: } 35.23 \\
\text { end: } 25.64\end{array}$ & $\begin{array}{l}\text { start: } 43.96 \\
\text { end } 27.98\end{array}$ & $\begin{array}{l}\text { stant: } 34.18 \\
\text { end: } 20.98\end{array}$ \\
\hline Second Cleaning, & 0.5 & $\cdots$ & - & - & - & - & $\cdots$ & $\ldots$ \\
\hline $\begin{array}{l}\text { Third Filtration } \\
\text { interval }\end{array}$ & 2 & $\begin{array}{l}\text { start: } 46.62 \\
\text { end: } 32.64\end{array}$ & $\begin{array}{l}\text { start: } 48.95 \\
\text { end: } 18.65\end{array}$ & $\begin{array}{l}\text { start: } 24.47 \\
\text { end: } 24.24\end{array}$ & $\begin{array}{l}\text { start: } 27.35 \\
\text { end: } 24.86\end{array}$ & $\begin{array}{l}\text { start } 27.97 \\
\text { end: } 13.21\end{array}$ & $\begin{array}{l}\text { start:26.42 } \\
\text { end:17.10 }\end{array}$ & $\begin{array}{l}\text { start: } 46.62 \\
\text { end: } 30.30\end{array}$ \\
\hline Third Cleaning, & 0.5 & $\cdots$ & $\cdots$ & - & $-m$ & - & - & - \\
\hline $\begin{array}{l}\text { Fourth Filtration } \\
\text { interval }\end{array}$ & 1 & $\begin{array}{l}\text { start: } 43.13 \\
\text { end: } 32.64\end{array}$ & $\begin{array}{l}\text { start: } 38.46 \\
\text { end: } 30.30\end{array}$ & $\begin{array}{l}\text { start: } 24.24 \\
\text { end: } 17.32\end{array}$ & $\begin{array}{l}\text { start: } 37.30 \\
\text { end: } 14.65\end{array}$ & $\begin{array}{l}\text { slart: } 25.49 \\
\text { end: } 13.99\end{array}$ & $\begin{array}{l}\text { start: } 30.46 \\
\text { end: } 13.99\end{array}$ & $\begin{array}{l}\text { start: } 35.74 \\
\text { end:23.31 }\end{array}$ \\
\hline Fourth Cleaning, & 0.5 & $\cdots$ & $\cdots$ & $\cdots$ & - & $\cdots$ & $\cdots$ & $-\cdots$ \\
\hline $\begin{array}{l}\text { Final Water Flux } \\
\text { Test } \\
\end{array}$ & 1 & 55.93 & 60.91 & 58.47 & 58.17 & 90.14 & 87.18 & 45.17 \\
\hline $\begin{array}{l}\text { Overall Flux } \\
\text { recovered }(\%)\end{array}$ & - & 54.2 & 55.5 & 51.9 & 53.3 & 73.2 & 72.2 & 69.1 \\
\hline
\end{tabular}




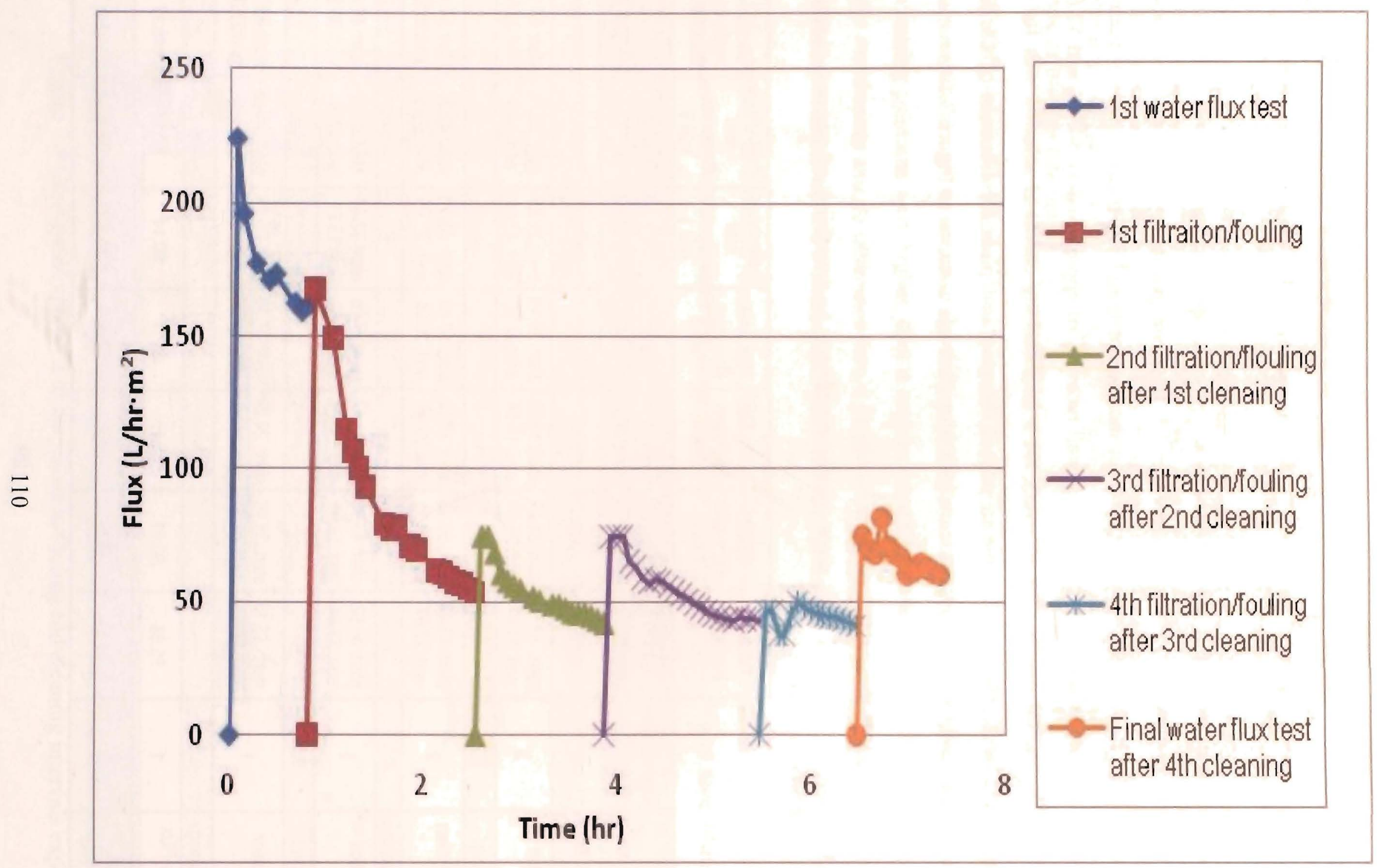

Figure 7.10 Membrane Filtration of CUBEN Effluent with Cleaning Intervals Using Sodium Hydroxide Backwashing, results of Trial 1. 
For the membrane soaking method an example of a graphical plot of the membrane cleaning method by soaking using hydrochloric acid is shown in Figure 7.11. The experimental run started with an initial water flux test for about one hour followed by filtration of CUBEN effluent for 3 hours until a steady flux was observed. The description with tabulated data is shown in Table 7.5. From the evaluation of the overall water flux for membrane soaking cleaning method the percent recovery was highest for the hydrochloric acid solution at a recovery of about $81.5 \%$, then the acetic acid at $71.1 \%$ and for the sodium hydroxide at $34.8 \%$ recovery of the water flux.

Hydrochloric acid resulted in the best overall flux recovery compared to the other cleaning chemical agents, for all cleaning methods of backwash, CEB and membrane soaking. This reveals that hydrochloric acid was the chemical most effective to remove foulants during the cleaning and revealing that majority of the foulants in the feed were cationic substances, such as hardness salts and metal hydroxides. These particular foulants are factors that cause concentration polarization (Asano et al. 2007).

Table 7.4 Tabulated data and flux recovery for chemical solutions used for membrane soaking

\begin{tabular}{|c|c|c|c|c|}
\hline & & \multirow[b]{2}{*}{$\begin{array}{l}\text { Hydrochloric Acid } \\
\text { Membrane } \\
\text { Soaking } \\
\end{array}$} & \multirow[b]{2}{*}{$\begin{array}{c}\text { Acetic Acid } \\
\text { Membrane } \\
\text { Soaking } \\
\end{array}$} & \multirow[b]{2}{*}{$\begin{array}{l}\text { Sodium Hydroxide } \\
\text { Membrane } \\
\text { Soaking } \\
\end{array}$} \\
\hline & & & & \\
\hline $\begin{array}{l}\text { Mode of Operation and } \\
\text { Feed }\end{array}$ & $\begin{array}{l}\text { Approximate } \\
\text { Time (hr) }\end{array}$ & Flux $\left(\mathrm{L} / \mathrm{hr} \cdot \mathrm{m}^{2}\right)$ & Flux $\left(\mathrm{L} / \mathrm{hr} \cdot \mathrm{m}^{2}\right)$ & Flux $\left(\mathrm{Lhr} \cdot \mathrm{m}^{2}\right)$ \\
\hline Iniital Water Flux Test & 1 & 91.55 & 115.622 & 146.08 \\
\hline First Filtration Interval & 3 & $\begin{array}{l}\text { start: } 45.45 \\
\text { end: } 41.29\end{array}$ & $\begin{array}{l}\text { start: } 67.60 \\
\text { end: } 50.17\end{array}$ & $\begin{array}{l}\text { start: } 103.34 \\
\text { end: } 26.42\end{array}$ \\
\hline First Cleaning. & 3 & $\ldots$ & $\ldots$ & $\ldots$ \\
\hline Second Filtration Interval & 2 & $\begin{array}{l}\text { start: } 74.59 \\
\text { end: } 39.63\end{array}$ & $\begin{array}{l}\text { start: } 73.82 \\
\text { end: } 34.97\end{array}$ & $\begin{array}{l}\text { start: } 53.03 \\
\text { end: } 27.97\end{array}$ \\
\hline Second Cleaning, & 3 & $-\cdots$ & - & $\ldots$ \\
\hline Third Filtration Interval & 2 & $\begin{array}{l}\text { start: } 44.29 \\
\text { end: } 22.92\end{array}$ & $\begin{array}{l}\text { start: } 48.95 \\
\text { end: } 28.36\end{array}$ & $\begin{array}{l}\text { start: } 59.05 \\
\text { end: } 41.96\end{array}$ \\
\hline Third Cleaning, & 3 & $\cdots$ & $\cdots$ & $\cdots$ \\
\hline Fourth Filtration Interval & 1 & $\begin{array}{l}\text { start: } 43.12 \\
\text { end: } 32.64\end{array}$ & $\begin{array}{l}\text { start: } 38.46 \\
\text { end: } 30.30\end{array}$ & $\begin{array}{l}\text { start: } 49.73 \\
\text { end: } 32.64\end{array}$ \\
\hline Fourth Cleaning, & 3 & -- & - & - \\
\hline Final Water Flux Test & 1 & 74.6 & 82.17 & 50.77 \\
\hline $\begin{array}{l}\text { Overall flux } \\
\text { recovered } \%\end{array}$ & $-\cdots$ & 81.5 & 71.1 & 34.8 \\
\hline
\end{tabular}




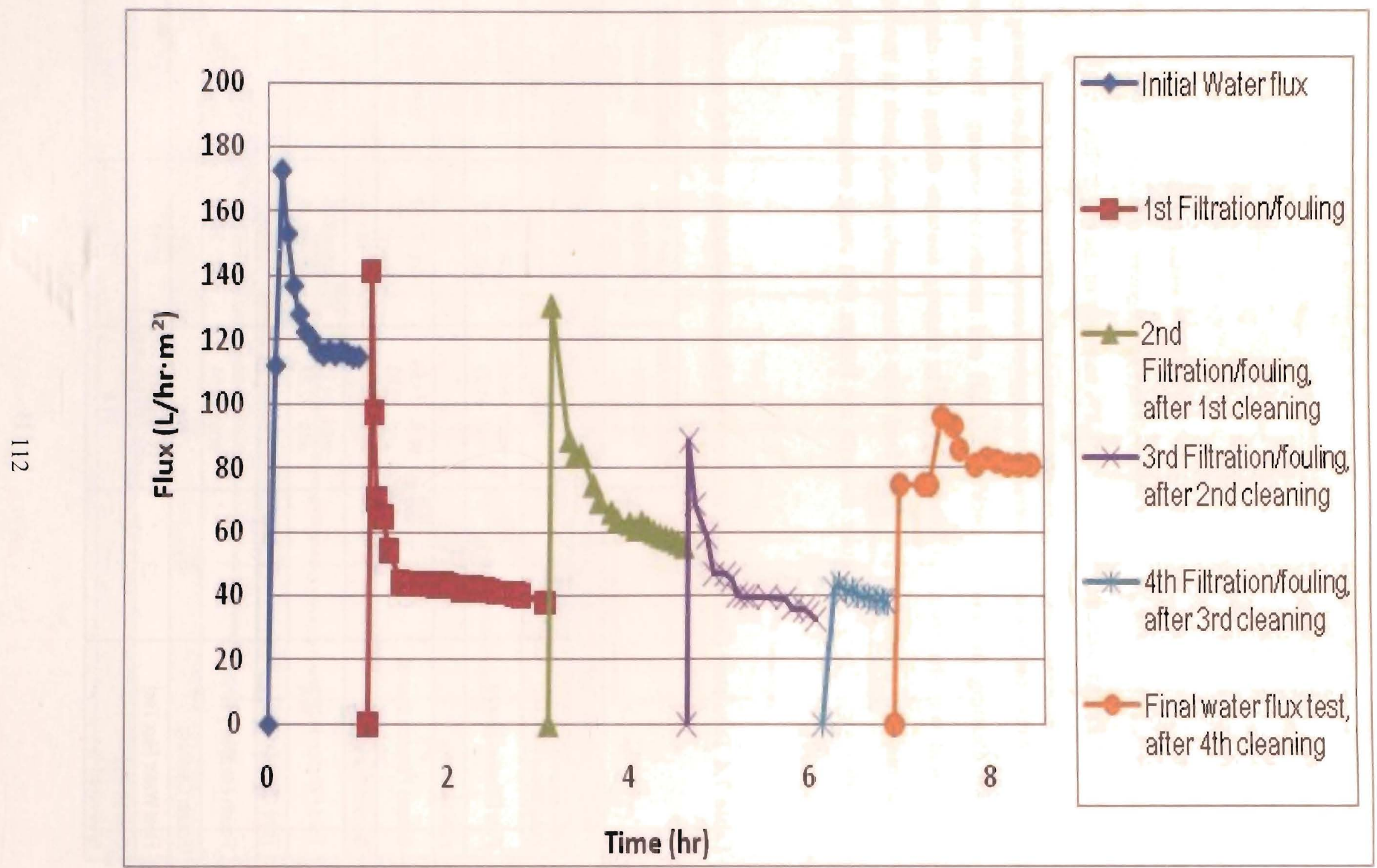

Figure 7.11 Membrane Filtration of CUBEN Effluent with Cleaning Intervals Using Hydrochloric Acid Backwashing 


\subsection{CONCLUSIONS}

A ceramic membrane unit was designed, built and calibrated in the laboratory. Further, operation and study of the unit for membrane cleaning/regeneration of an aqueous solution and for wastewater from a biological nutrient removal (BNR) unit were investigated for overall efficiency. Here summarized are the overall conclusions:

$>$ The membrane unit designed was able to treat a variety of solution feeds with suspended solids greater than $100 \mathrm{mg} / \mathrm{L}$. Also the unit was able to operate at TMP as high as 4 atmospheres and inlet feed flow rates of about $6.6 \mathrm{~L} / \mathrm{hr}$.

D Initial water flux (membrane permeability) tests found that the unit met the manufacturer's specifications and hence the apparatus was properly designed.

D When the aqueous solution containing precipitate was filtered, at various TSS concentrations as high as $85 \mathrm{mg} / \mathrm{L}$, through the unit, permeate TSS concentrations no higher than $2 \mathrm{mg} / \mathrm{L}$ was always obtained. This meets the minimum effluent discharge to receiving waters of $25 \mathrm{mg}$ of suspended solids $/ \mathrm{L}$ set by Environment Canada, Guidelines for Effluent Quality and Wastewater treatment at Federal Establishments.

The second part of this thesis involved membrane fouling and cleaning. Different cleaning solutions were used to determine the best cleaning solution and method. Concentrations of all the cleaning solutions used were less than $1 \% \mathrm{wt}$, so to minimize the amount of chemicals used. The methods entailed backwashing and chemically enhanced backwashing. Introduction of a wastewater feed that originated from a bioreactor was used. It was found that:

Filtration of the wastewater feed was introduced through the unit and permeate TSS concentrations of less than or equal to $3 \mathrm{mg} / \mathrm{L}$ and turbidities of less than 1 NTU was always obtained. This was at various feed concentrations as high as $121 \mathrm{mg} / \mathrm{L}$ and as low as 12 $\mathrm{mg} / \mathrm{L}$. 
$>$ For the backwash methods, average recoveries of; at the highest $72.7 \%$ for the hydrochloric acid cleaning solution, $69.1 \%$ for sodium hydroxide, $54.8 \%$ for water and the lowest at $52.6 \%$ for acetic acid cleaning agent.

$>$ In addition, for chemical cleaning by membrane soaking the result was that hydrochloric acid had the best flux recovery at $81.5 \%$, then acetic acid at $71 \%$ and sodium hydroxide at approximately $35 \%$.

Overall the apparatus performed well to the various operating conditions and feed solutions of which are typically employed in industry applications. 


\subsection{RECOMMENDATIONS}

The ceramic membrane unit that has been built in the laboratory is sufficient to the current study. However, additional attempts may be applied to the process and equipment to further advance research. They are listed as follows:

$>$ Further studies applying different feed solutions or cleaning solutions may be trialed. This can include:

- further experimental matrix correlations, for example various feed flow rates versus different pressures applied

$>$ Evaluate the ceramic membranes based on pore sizes for some required filtration needs.

$>$ Select and test different filtration and fouling models in ceramic membranes for different mode of operation (i.e. dead-end and cross-flow).

To increase the treatment capacity of the unit.

(e.g. more membranes in parallel or a larger membrane housing to house a number of membranes).

$>$ To modify the set-up of the apparatus to easily facilitate automated cleaning of the membranes. This may involve:

- an automated backwashing pump incorporated with pressure regulators, or

- an additional feed tank connected in-line with the piping to the feed pump to hold cleaning solutions, or

- addition of alternative cleaning devices such as, ultrasound devices. 


\section{BIBLIOGRAPHY}

Adham S., Gagiiardo P. Membrane Bioreactors for Water Repurification - Phase 1, Desalination Research and Development Program Report No. 34. U.S. Department of the Interior., U.S.A. 1998.

Ahmed Z., Cho J., Lim B., Song K., Ahn K. (2007). Effects of sludge retention time on fouling and microbial community structure in a membrane bioreactor. Journal of Membrane Science. v. 287, pp. 211-218.

Ahn K.H., Song K.G., Cho E.S., Cho J.W., Yun H., Lee S., Kim J. (2003). Enhanced biological phosphorous and nitrogen removal using a sequencing anoxic/anaerobic membrane bioreactor (SAM) process. Desalination. 157, 345-352.

A1-Amoudi A., Lovitt R.W., (2007). Fouling strategies and the cleaning system of NF membranes and factors affecting cleaning efficiency. Journal of Membrane Science. v. 303, pp. 4-28.

Asano T., Metcalf and Eddy, Leverenz H.L., Tsuchihashi R., Tchobanoglous G. Water Reuse Issues, Technologies, and Applications. McGraw-Hill Professional., U.S.A. 2007

AWWARF (American Water Works Association Research Foundation), Lyonnaise des Eaux, Water Research Commission of South Africa. Water Treatment Membrane Processes. R.R. Donnelley \& Sons Company, U.S.A. 1996

Baker R.W. Membrane Technology and Applications. McGraw-Hill. U.S.A., 2000

Barlow M., Blue covenant: the global water crisis and the coming battle for the right to water. McClelland \& Stewart Ltd., Toronto. 2007

Bernardo P., Criscuoli A., Clarizia G., Barbieri G., Drioli E., Fleres G., Piccioti M. (2004). Applications of membrane unit operations in ethylene process. Clean Technologies and Environmental Policy. vol. 6, no. 2, pp. 78-95.

Bitton, G.,, Wastewater Microbiology, Third Edition. John Wiley \& Sons, Inc., U.S.A. 2005

Blanpain-Avet P., Migdal J.F., Bénézech T. (2009). Chemical cleaning of a tubular ceramic microfiltration membrane fouled with a whey protein concentrate suspension-Characterization of hydraulic and chemical cleanliness. Journal of Memrbane Science. V. 337, pp. 153-174.

Bourgeous K., Darby J., Tchobanoglous G. (2000). Ultrafiltration of Wastewater: Effects of particles, Mode of operation, and Backwash Effectiveness. Water Research. v.35, n.1, pp.77-90.

Bruijn J.P.F., Salazar F.N., Bórquez R. (2005). Membrane Blocking in Ultrafiltration: A New Approach to Fouling. Institution of Chemical Engineers. v.83, pp.211-219. 
Chang I.S., Le Clech P., Jefferson B., Judd S. (2002). Membrane Fouling in Membrane Bioreactors for Wastewater Treatment. Journal of Environmental Engineering. v.128, n.11, pp.1018-1029.

Chen D., Ultrasonic Control of Ceramic Membrane Fouling caused by Silica Particles and Dissolved Organic Matter. Diss The Ohio State University, U.S.A., 2005.

Choi J.G.., Bae T.H., Kim J.H., Tak T.M., Randall A.A., (2002). The behavior of membrane fouling initiation on the cross-flow membrane bioreactor system. Journal of Membrane Science, v.203, p.103-113.

Chu R., Study Examines Membrane Filtration Market. WaterWorld 2009. Retreived August 18, 2009 from http:/www.waterworld.com/WaterWorld/en-us/index/display/articledisplay.articles.waterworld.volume-21.issue-5.editorial-focus.study-examines-membrane-filtrationmarket.htmlhtml

Cicek N. (2003). A review of membrane bioreactors and their potential application in the treatment of agriculture wastewater. Biosystems Engineering. v.45, pp. 6.37-6.49.

Ciora R. J., Liu P. (2003). Ceramic Membranes for Environmental Related Applications. Fluid/Particle Separation Journal. 15, 1, 51-60.

Côté P., Masini M., Mourato D. (2004)..Comparison of membrane options for water reuse and reclamation. Desalination. V. 167, pp. 1-11.

Costa C.A., Cabral J.S. Chromatographic and membrane processes in biotechnology

Crittenden J.C., Trussell R.R., Hand D.W., Howe K.J., Tchobanoglous G. Water Treatment: Principles and Design. Second Edition. [electronic resource]. Wiley 2005

Degueldre C, Scholtis A, Pearson FJ, Laube A, Gomez P. (1999). Effect of sampling conditions on colloids and groundwater chemistry. Eclogae geol. Helvet. v.2, n. 1, pp.105-114.

Desai M.A., Downstream Processing of Proteins Methods and Protocols. Humana Press Inc. U.S.A., 2000

Deqian R., (1987). Cleaning and Regeneration of Membranes. Desalination., v.62, pp.363-371.

Do Rego Monteiro V.A., de Souza E.F., de Azevedo M.M.M., Galembeck F. (1999). Aluminum Polyphosphate Nanoparticles: Preparation, Particle Size Determination, and Microchemistry. Journal of Colloid and Interface Science. v.217, pp. 237-248.

Drews A., Mante J., Iversen V., Vocks M., Lesjean B., Kraume M. (2007). Impact of ambient conditions on SMP elimination and rejection in MBRs. Water Research, 41, 3850-3858.

Eckenfelder, W.W., Industrial Water Pollution Control. 3rd Edition, United States of America: McGraw-Hill Companies, Inc. 2000 
Edlund D.J., Composite hydrogen separation element and module, U.S.Patent 5,498,278 (1996).

Emanuelsson E.A.C., Arcangeli J.-P., Livingston A.G.. (2003). The anoxic extractive membrane bioreactor. Water Research. v. 37, pp. 1231-1238.

Field R.W., Wu D., howell J.A., and Gupta B.B. (1995). Critical flux concept for microfiltration fouling. Journal of Membrane Science. v.100, pp.259-272.

Fleischer E.J., Broderick T.A., Daigger G..T., Fonseca A.D. (2005). Evaluation of membrane bioreactor process capabilities to meet stringent effluent nutrient discharge requirements. Water Environment Research. v. 77, n. 2, pp.162-178.

Freedonia Group Inc., Membrane Separation Technologies to 2012: Market Research, Market Share, Market Size, Sales, Demand Forecast, Market Leaders, Company Profiles, Industry Trends., United States, 2008

Garmash E.P., Kryuchkov Y.N., Pavlikov V.N. (1995). Ceramic Membranes for Ultra- and Microfiltration (Review). Glass for Ceramics Production. Plenum Publishing Corporation. 52, 5-6, $150-152$.

Gerardi, M. H., Wastewater Bacteria. Wiley-Interscience., U.S.A. 2006

Hermia J. (1982).Constant pressure blocking filtration laws-Application to power-law nonnewtonian fluids. Institution of chemical Engineers. V.60, pp.183-187.

Ho C.C., Zydney A.L. (2000). A Combined Pore Blocking and Cake Filtration Model for Protein Fouling during Microfiltration. Journal of Colloid and interface Science. v.232, pp.389-399.

Hosni K., Moussa S.B., Amor M.B. (2007). Conditions influencing the removal of phosphate from synthetic wastewater: influence of the ionic composition. Desalination. V.206, pp. 279-285.

Hwang K.J., Liao C.Y., Tung K.L. (2008). Effect of membrane pore size on the particle fouling in membrane filtration. Desalination. v.234, pp.16-23.

Huang H., Young T.A., jacangelo J.G. (2008). Unified Memrbane Fouling Index for low Pressure Membrane Filtration of Natural Waters: Principles and Methodology. Environmental Science and Technology. v.42, n.3, pp.714-720.

Hygnstrom J., Woldt W. Residential On-site Wastewater Treatment: Lagoon Design and Construction. University of Nebraska-Lincoln Extension., U.S.A., 2004

Ibarz A., Barbosa-Cánovas G.V. Unit Operations in Food Engineering. CRC Press LLC, U.A.S., 2003

Innovative Technology. Crossflow Filtration: Tanks Focus Area. U.S.A., 1998 
Iritani E., Katagiri N., Tadama T., Sumi H. (2009). Analysis of clogging behaviours of diatomaceous ceramic membranes during membrane filtration based upon specific deposit. American Institute of Chemical Engineers. v.56, pp.1748-1758.

Jang N., Ren X., Kim G., Ahn C., Cho J., Kim I. (2007). Characteristics of soluble microbial products and extracellular polymeric substances in the membrane bioreactor for water reuse. Desalination, 202, 90-98.

Jarusutthirak C., Mattaraj S., Jiraratananon R. (2007). Influence of inorganic scalants and natural organic matter on nanofiltration membrane fouling. Journal of membrane Science. v.287, pp.138145 .

Judd S., (2002). Submerged Membrane Bioreactors: Flat Plate or Hollow Fibre. Filtration and Separation. pp.30-31.

Judd S., The MBR Book: Principles and Applications of Membrane Bioreactors in Water and Wastewater Treatment. Elsevier Ltd., Great Britain. 2006

Judd S., (2008). The status of membrane bioreactor technology. Trends in Biotechnology. v. 26, n. 2, pp. $109-115$.

Kasprzyk-Hordern B. (2004). Chemistry of alumina, reactions in aqueous solution and its application in water treatment. Advances in Colloid and interface Science. v.110, pp.19-48.

Katsoufidou K., Yiantsios S.G., Karabelas A.J. 92005). A study of ultrafiltration membrane fouling by humic acids and flux recovery by backwashing: experiments and modeling. Journal of Membrane Science. v.266, pp.40-50.

Kim, C.G., Yoon, T.I., Lee, M.J. (2002). Characterization and control of foulants occurring from RO disc-tube-type, membrane treating, fluorine manufacturing, process wastewater. Desalination. v. 151, pp. 283-292.

Kim J.S., Deng Q., Benjamin M.M. (2008). Simultaneous removal of phosphorous and foulants in a hybrid coagulation/membrane filtration system. Water Research. v. 42, pp. 2017-2024.

Kumar S.M., Madhu G.M., Roy S. (2007). Fouling behaviours, regeneration options and on-line control of biomass-based power plant effluents using microporous ceramic membranes. Separation and Purification Technology. V.57, pp.25-36.

Kumar S.M., Roy S. (2008). Recovery of Water from Sewage Effluents using Alumina Ceramic Microfiltration Membranes. Separation Science and Technology. V.43, pp.1034-1064.

Kyllönen H.M., Pirkonen P., Nyström M. (2005). Membrane Filtration enhanced by ultrasound: a review. Desalination. v. 181, pp. 319-335.

Laitinen, N., Development of aceramic membrane filtration equipment and its applicability for 
different wastewaters. Diss Lappeenrannan teknillinen korkeakoulu, Finland. 2002

Lee S.Y., Cho J.W. (2004). Comparison of ceramic and polymeric membranes for natural organic matter (NOM) removal. Desalination. v.160, pp.223-232.

Leiknes T., Ødegaard H. (2007). The development of a biofilm membrane bioreactor, Desalination. V.202, pp.135-143.

Li, J., Sanderson, R.D., Jacobs, E.P. (2002). Ultrasonic cleaning of nylon microfiltration membranes fouled by Kraft paper mill effluent. Journal of Membrane Science, v. 205, pp. 247-257.

Li, K. Ceramic membranes for separation and reaction. John Wiley \& Sons Ltd., England. 2007

Li N., Fane A.G., Ho W.S.W., Matauura T. Advanced membrane Technology and Applications. John Wiley and Sons Inc., U.S.A., 2008

Li Q., (2008). Antimicrobial nanomaterials for water disinfection and microbial control: Potential applications and implications. Water Research. v. 42, pp. 4591-4602.

Liu W., Howell J.A., Arnot T.C., Scott J.A. (2001) A novel extractive membrane bioreactor for treating biorefractory organic pollutants in the presence of high concentrations of inorganics: application to a synthetic acidic affluent containing high concentrations of chlorophenol and salt. Journal of Membrane Science. v. 181, pp. 127-140.

Liao B.Q., Bagley D.M., Kraemer H.E., Leppard G.G., liss S.N. (2004). A Review of Biofouling and its Control in Membrane Separation Bioreactors. Water Environment Research. v.76, n.5, pp.425-426.

MacDonald D. D., Apparatus for Measuring the $\mathrm{pH}$ of a Liquid. U.S.A. 1983.

Manariotis I.D., Grigoropoulos S.G. (2006). Anaerobic filter treatment of municipal wastewater: Biosolids behaviour. Journal of Environmental Engineering. v.132, n.1, pp.23-31.

Mann N.R., Herbst R.S., Hess J.R., Kochergin V. (2004). Enhanced flux, erosion resistant membranes for biomass separations-Part 1. Membrane Technology. v. 2004, n. 11, pp. 5-9.

Mallia H., Till S. (2001). Membrane Bioreactors: Wastewater Treatment Applications to Achieve High Quality Effluents. Australia: WIOA, Retrieved September 20, 2008 from http://wioa.org.au/conf_papers/01/paper8.htm.

Marcano J.G.S., Tsotsis T.T., (2002). Membranes and Membrane Reactors. Germany: Wiley-VCH. Maroulis ZB., Saravacos G.D. Food Process Design. Marcel Dekker Inc. U.S.A., 2003

Marrot B., Barrios-Martinez A., Moulin P., Roche N. Industrial Wastewater Treatment in a Membrane Bioreactor: A Review. Environmental Progress. v. 23, n. 1, pp. 59-68. 
Masselin, I., Chasseray, X., Durand, B.L., Laine, J.M., Syzaret, P.Y. (2001). Effect of sonication on polymeric membranes. Journal of Membrane Science. v. 181, pp. 213-220.

Mempro. (2005). Ceramic Membranes: A Robust Filtration Alternative. Filtration and Separation. pp. 34-37.

Metcalf and Eddy. Wastewater Engineering, Treatment and Reuse. Fourth Edition. McGraw-Hill. U.S.A., 2003

Mulder M., Basic Principles of Membrane Technology. Kluwer Academic Publishers. Netherlands. 1996

Ng A.N.L., Kim A.S. (2007). A mini-review of modeling studies on membrane bioreactor (MBR) treatment for municipal wastewaters. Desalination., v. 212, pp. 261-281.

Nicolaisen B., (2010). Membranes: Fouling and Cleaning. Water Quality Products. v.7, n.5.

Nopens I., Sin G., Jiang T., d'Antonio L., Stama S., Zhao J., Vanrollegham P.A. (2007). Modelbased optimization of the biological performance of a sidestrean MBR. Water Science \& Technology. v. 56, n. 6 , pp. $135-143$.

Nunes S.P. and Peinemann K.V. Membrane Technology. Wiley-VCH Verlag GmbH \& Co. KGaA., Germany. 2006

Omil F., Garrido J.M., Arrojo B., Mendez R. (2002). Anaerobic filter reactor performance for the treatment of complex dairy wastewater at industrial scale. Water Research. v.37, pp.4099-4108.

Ousman M., Bennasar M. (1995). Determination of various hydraulic resistances during cross-flow filtration of a starch grain suspension through inorganic membranes. Journal of Memrbane Science. v.105, pp.1-21.

Park J.S., Yeom K.M., Lee C.H. (2005). Hydrodynamics and microbial physiology affecting performance of a new MBR, membrane-coupled high-performance compact reactor. Desalination. v. 172, n. 2, pp. 181-188.

Parco V., du Toit G., Wentzel M., Ekama G. (2007). Biological nutrient removal in membrane bioreactors: denitrification and phosphorus removal kinetics. Water Science and Technology. v. 56, n. 6 , pp. 125-134.

Peinemann K.V., Nunes S.P. Membrane Technology: Volume 4: Membranes for Water Treatment. Wiley-VCH, Germany. 2010

Peng J., Xue G. (2006). Mathematical Modeling of Hollow-fiber Membrnae System in Biological Wastewater Treatment. Journal of Systemics, Cybernetics and Informatics. V.4, n.1, pp.41-52.

Porcelli N., Judd S. (2010). Chemical cleaning of portable water membranes: A review. Separation 
and Purification Technology. v. 71, pp. 137-143.

Porter M.C., Handbook of Industrial Membrane Technology. William Andrew Inc., U.S.A. 1990

Potyomkina TG, Potyomkin VL. (2005). Study of the chemical composition of suspended particles in Lake Baikal. Lakes \& Reservoirs: Research and Management .v. 3, pp.133-6.

Professional Plastics. Thermal properties of Plastic Materials. Retrieved August 15, 2010, from http://www.google.ca/\#hl=en\&source=hp\&q=Thermal+Properties+of+Plastic+Materials\&aq=f\&aqi $=\& a q l=\& o q=\& g s \_r f a i=\& f p=f 2 f e f d 70 e 73 a b 78 f$

Ratledge C., Kristiansen B. Basic Biotechnology. Cambridge University Press. U.K., 2001

Rhoida Eco Services. (1998). A New Development in Membrane Bioreactors: Increasing the capacity of existing biological treatment plants. Filtration and Separation. v. 35, n. 8, pp. 792-795.

Roorda J., (2004). Filtration Characteristics in dead-end ultrafiltration of wwtp-effleunt. Jelle Roorda. Netherlands

Rosenberger S., Laabs C., Lesjean B., Gnirss R., Amy G., Jekel M., Schrotter J.-C. (2006). Water Research.v.40, pp.710-720.

Rushton A., Ward A.S., Holdich R.G. Solid Liquid Filtration and Separation Technology. VCH Verlagsgesellschaft mbH., Germany. 1996

Schmit F.L., Redmon D.T., Ewing L. (1990). In Place Gas Cleaning of Diffusion Elements. U.S.A.

Seader and Henley. Separation Process Principles. John Wiley and Sons., U.S.A., 1998.

Shim J.H., Cha S.W., O'Hayre R., Gür T.M., Prinz F.B. (2006). Proton Transport Membranes for Fuel Cells: Polymeric versus Dense Ceramic. ECS Transactions, the Electrochemical Society. v.3, n.1, pp.1059-1068.

Shu L., Xing W., Xu N. (2007). Effect of Ultrasound on the Treatment of Emulsification Wastewater by Ceramic Membranes. Chin. J. Chem. Eng. 15, 6, 855-860.

Shuler M.L., Kargi F. Bioprocess Engineering Basic Concepts. Second Edition. Prentice Hall PTR., 2002

Singh B., Sheth A.C., Dahotre N.B. (2006). Laser synthesis of palladium-alumina composite membranes for production of high purity hydrogen from gasification. Applied Surface Science. 235, p.1247-1254.

Song L., (1998). Flux decline in crossflow microfiltration and ultrafiltration: mechanisms and modeling of membrane fouling. Journal of Membrane Science., v.139, pp. 183-200. 
Song L., Elimelech M. (1995). Theory of Concentration Polarization in Crossflow Filtration. Journal of the Chemical Society, Faraday Transactions. v.91, pp.3389-3398.

Spellman, F.R., Handbook of Water and Wastewater Treatment Plant Operations. Lewis Publishers., U.S.A.2003

Stephanopoulos G., Kornfield J.A., Voecks G.E. Monolith reactor containing a plurality of flow passages and method for carrying out biological reactions. U.S.Patent 4948728 (1990).

Stephenson T., Judd S., Jefferson B., Brindle K. (2000). Membrane Bioreactors for Wastewater Treatment. London, England: IWA Publishing.

Strathmanm H. (2001). Membrane Separation Processes: Current Relevance and Future Opportunites. AIChE Journal. v. 47, n. 5, pp. 1077-1087.

Strathmanm H., Giorno L., Drioli E. An Introduction to Membrane Science and Technology. Consiglio Nazionale Delle Riccerche Roma, Italy. 2006

Sutherland K., Profile of the international membrane industry: market prospects to 2008. Elsevier Ltd., 2004

Taylor J.S., Duranceau S.J., Proceedings from the International Conference on Membrane Technology in Water and Wastewater Treatment, Membrane case studies, past present and future. MPG Books Ltd. U.K., 2000

Tchobanoglous G., Darby J., Bourgeous K., mcArdle J., Genest P., Tylla M. (1998). Ultrafiltration as an advanced tertiary treatment process for municipal wastewater. Desalination. v.119, pp.315322.

U.S.EPA (Environmental Protection Agency), September 1989, Design Manual Fine Pore Aeration Systems, U.S.A.

U.S.EPA (Environmental Protection Agency), November 2005, Membrane Filtration Guidance Manual. U.S.A.

U.S.EPA (Environmental Protection Agency), April 2008, Sequencing Batch Reactor Systems. [http://www.epa.gov/nrmrl/pubs/625r00008/html/html/tfs3.htm]

Valsami-Jones E. ed. Phosphorus in Environmental Technologies: Principles and Applications. IWA Publishing. U.K., 2004

Väisänen P., (2004). Characterization of clean and Fouled Polymeric Membrane Materials. Acta Universitatis Lappeenrantaensis 180, Finland. 
Vela M.C., Blanco S.A., García J.L., Rodríguez E.B. (2008). Analysis of membrane pore blocking models applied to the Ultrafiltration of PEG. Separation and Purification Technology. v. 62, pp. 489-498.

Visvanathan C., Ben Airm R., Parameshwaran K. (2000). Membrane separation bioreactors for wastewater treatment. Critical Reviews in Environmental Science and Technology. v.30, n.1, pp. 148.

Wakeman R.J., Solid/Liquid Separation: Principles of Industrial Filtration. Elsevier Ltd., U.K. 2005.

Water and Wastewater News. BCC Research: Membrane Market Worth $\$ 3$ B in 2013. Editor: Williams L.K., 2008. Retrieved August 18, 2009 from http://wwn-online.com/articles/69117/

Water Environment Federation (WEF). Membrane Systems for Wastewater Treatment. McGrawHill Companies. U.S.A., 2006

Weber W. J., Physicochemical Processes for Water Quality Control. Wiley-Interscience, New York, 1972

WEF (Water Environment Federation) Webcast, Membranes 101: Fundamentals of Membrane Bioreactors (MBRs) and Tertiary Membrane Filtration (TMF). November $4^{\text {th }}, 2009$

Wintgens T., Rosen J., Melin T., Brepols C., Drensla K., Engelhardt N. (2003). Modeling of a membrane bioreactor system for municipal wastewater treatment. Journal of Membrane Science. v.216, pp.55-65.

(WIPO) World Intellectual Property Organization. Media for a Rotating Biological Contactor. U.S.A., 1996 [http://www.wipo.int/pctdb/en/wo.jsp?IA=WO1996005144\&DISPLAY=DES]

World Membrane Markets. 2009. Retrived August 18, 2009, from http://www.reportlinker.com/p0116330/World-Membranes-Market.html

Yang W., Cicek N., Ilg J. (2006). State-of-the-art of membrane bioreactors: Worldwide research and commercial applications in North America. Journal of Membrane Science. 270, 201-211.

Yoem I.T., Nah Y.M., Ahn K.H. (1999). Treatment of household wastewater using an intermittently aerated membrane bioreactor. Desalination. V. 124, pp. 193-204

Yuan W., Kocic A., Zydney A.L. (2002). Analysis of humic acid fouling during microfiltration using a pore blockage-cake filtration model. Journal of Membrane Science. v.198, pp.51-62.

Zeman L.J., Zydney A. L. Microfiltration and Ultrafiltration: Principles and Applications. Marcell Dekker Inc. U.S.A., 1996

Zhang B., Ma S. (2009). Study on Fouling and Cleaning of PVDF Membrane. Modern Applied Science. v. 3, n 11, pp.52-58. 
Zhong J., Sun X.J., Wang C. (2003). Treatment of oily wastewater produced from refinery processes using flocculation and ceramic membrane filtration. Separation and Purification Technology. v. 32, n. 1-3, pp. 93-98.

Zhong J., Huang R. (2006) Cleaning of ceramic membranes used to washing the nanometer $\mathrm{TiO}_{2}$ powder. Desalination. v.200, pp.64-65 


\section{APPENDICIES}

\section{Appendix A. Suppliers}

\section{Membrane Suppliers}

Table A.1. Membrane suppliers according to module elements. The following lists some companies and the trademark name of the particular membrane configuration they produce.

\begin{tabular}{|c|c|c|c|}
\hline Tubular & Hollow fibre & Plate & Spiral Wound \\
\hline $\begin{array}{l}\text { Diacel, Hoechst, } \\
\text { Membrane Products } \\
\text { Kiryat Weizmann, } \\
\text { Nitto Denko }\end{array}$ & $\begin{array}{l}\text { A/G Technology (Maxcell, } \\
\text { MaxiFiber, TurboTube), } \\
\text { Akzo (Microdyn), } \\
\text { Amicon (ProFlux), } \\
\text { Asahi Kasei/Pall (Microza), } \\
\text { DowiFilm Tec (SelectFlo), } \\
\text { Hoechst/Diacel (Molsep), } \\
\text { Microgon (Krosflo } \\
\text { Dynafibre) }\end{array}$ & $\begin{array}{l}\text { Dow/Film Tech (FilmTec), } \\
\text { Hoechst (Nadir), } \\
\text { SRT Inc. (Dualport, } \\
\text { Quadport), } \\
\text { Pall Filtron, } \\
\text { Sartorius (Sartocon II), } \\
\text { Membrane Products Kiryat- } \\
\text { Weizmann Lid., } \\
\text { Millipore (Prostrak, } \\
\text { Pellicon), } \\
\text { Tech-Sep (IRIS) }\end{array}$ & $\begin{array}{l}\text { Advanced Membrane } \\
\text { Technology, } \\
\text { Amicon, } \\
\text { Desalination Systems Inc., } \\
\text { Dow Chemical, } \\
\text { Fluid Systems, } \\
\text { Koch, Millipore, } \\
\text { Osmonics }\end{array}$ \\
\hline
\end{tabular}

Table A.2. List of various membrane manufacture companies for different industries.

- Air Products and Chemicals Incorporated

- Applera Corporation

- Applied Membranes Incorporated

- APV, see SPX Corporation

- Aquious-PCI Membrane Systems Incorporated, see ITT Corporation

- Ballard Power Systems Incorporated

- Baxter Intemational Incorporated

- Becton, Dickinson and Company

- Bio-Rad Laboratories Incorporated

- BOC Group plc, see Linde Group

- Celgard Incorporated, see Polypore International Incorporated

- Corning Incorporated

- Culligan International Company

- CUNO Incorporated, see 3M Company

- Daramic Incorporated, see Polypore International Incorporated

- Discovery Labware, see Becton, Dickinson and Company

- Donaldson Company Incorporated

- Dow Chemical Company

- DuPant (El) de Nemours

- Ecodyne Limited, see Marmon Group LLC

- EcoWater Systems LLC, see Marmon Group LLC

- Entegris Incorporated

- ESCO Technologies Incorporated

- FilmTec Corporation, see Dow Chemical Company

- Filtertek Incorporated, see Illinois Tool Works Incorporated 


\section{Continued from TableA.2}

- GE Water \& Process Technologies, see General Electric Company

- General Electric Company

- Gore (WL) \& Associates Incorporated

- Graver Technologies LLC, see Marmon Group LLC

- Hydranautics, see Nitto Denko Corporation

- Illinois Tool Works Incorporated

- Innovative Gas Systems Incorporated

- Invensys plc

- ITT Corporation

- Koch Industries Incorporated

- L'Air Liquide SA

- Linde Group

- Marmon Group LLC

- MEDAL LP, see L'Air Liquide SA

- Medtronic Incorporated

- Membrana GmbH, see Polypore International Incorporated

- Millipore Corporation

- Nitto Denko Corporation

- Pall Corporation

- Parker-Hannifin Corporation

- Polypore International Incorporated

- Praxair Incorporated

- PTI Technologies Incorporated, see ESCO Technologies Incorporated

- Sartorius AG

- Siemens AG

- Sigma-Aldrich Corporation

- Spectrum Laboratories Incorporated

- SpinTek Filtration LLC

- SPX Corporation

- Supelco, see Sigma-Aldrich Corporation

- 3M Company

- Whatman plc

- ZENON Environmental Incorporated, see General Electric Company

- Zhejiang Omex Environmental Engineering Company Limited, see Dow Chemical Company 
Table A.3. Ceramic Membrane Manufacturers

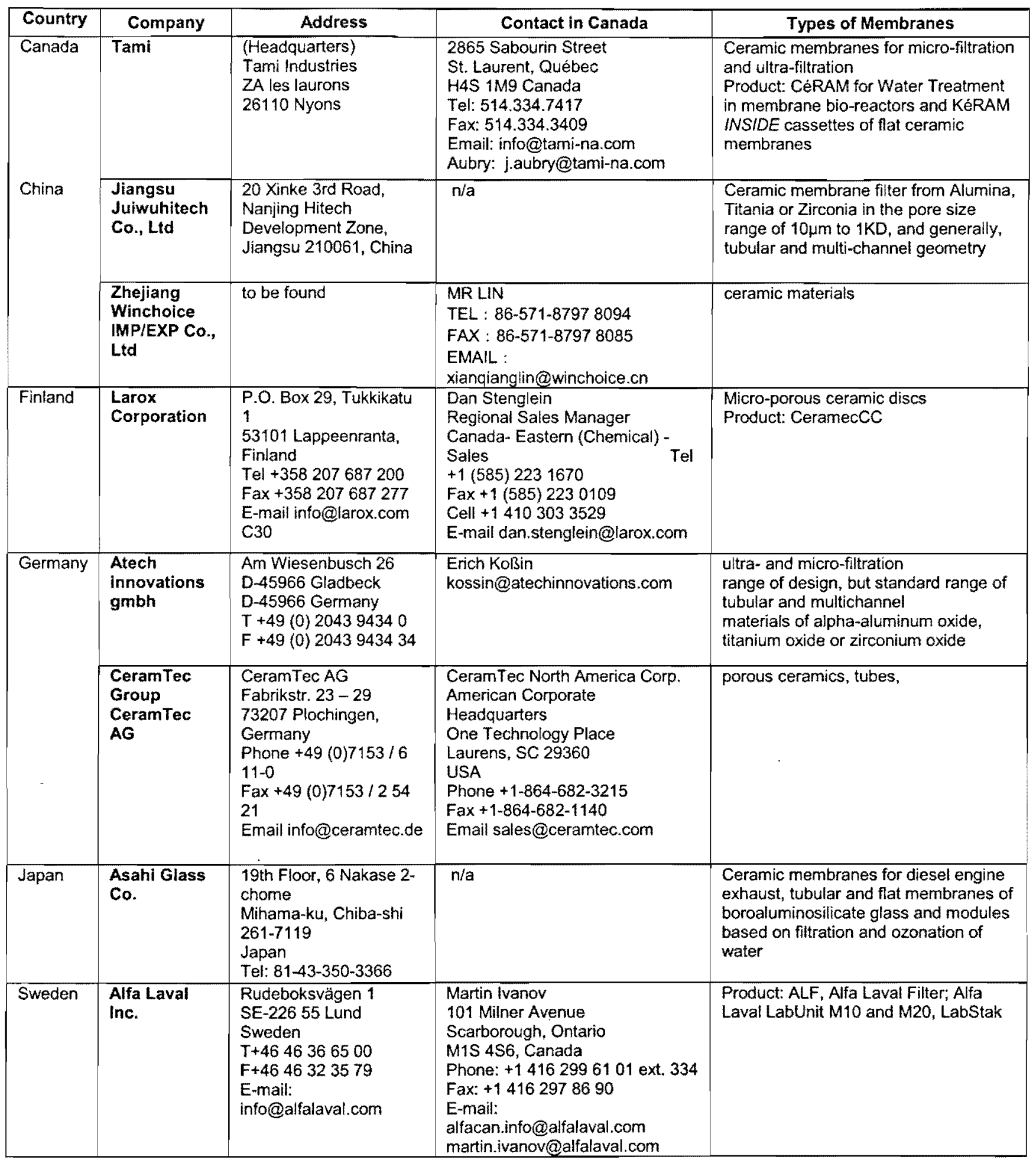


Continued from Table A.3

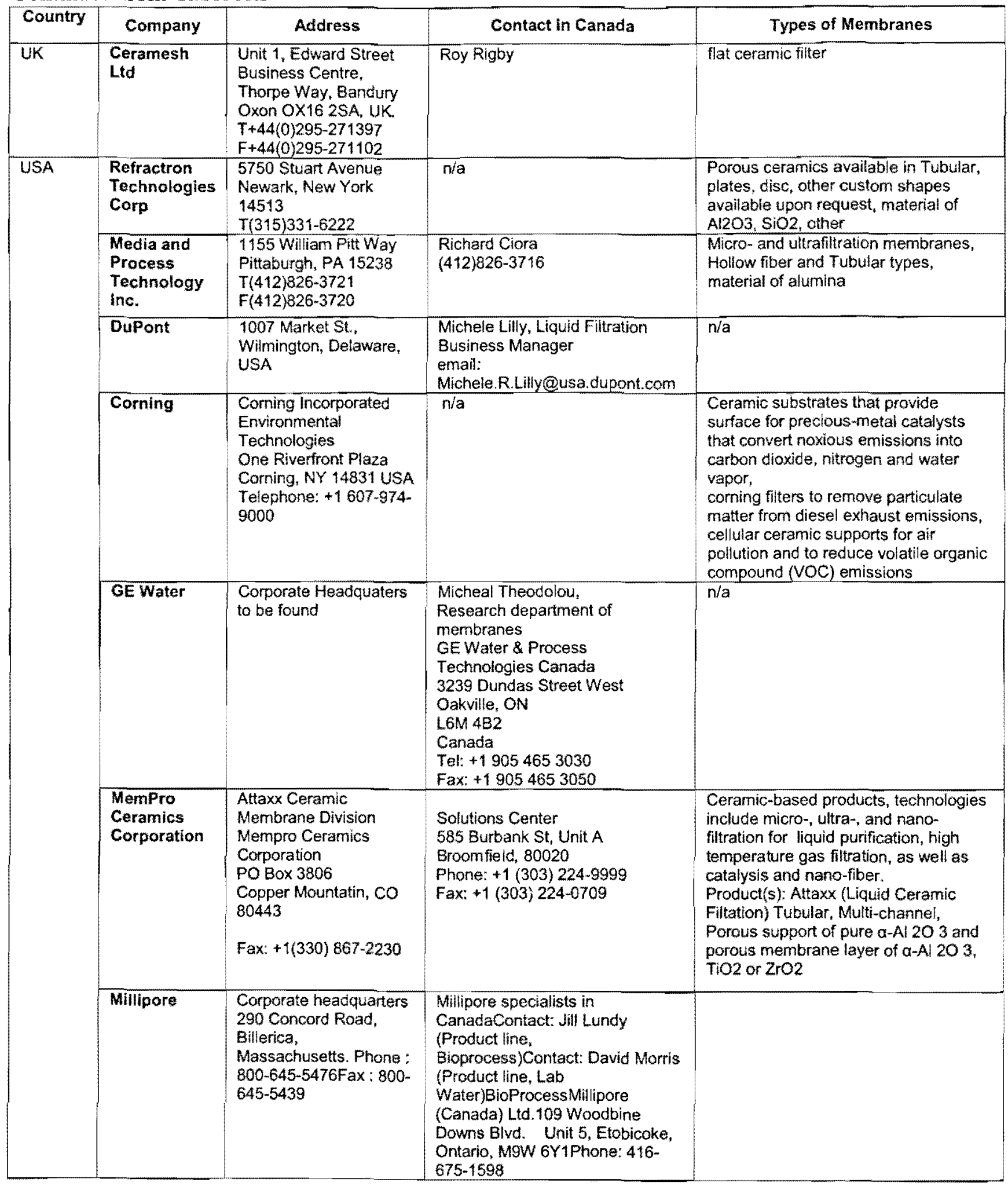




\section{Continued from Table A.3}

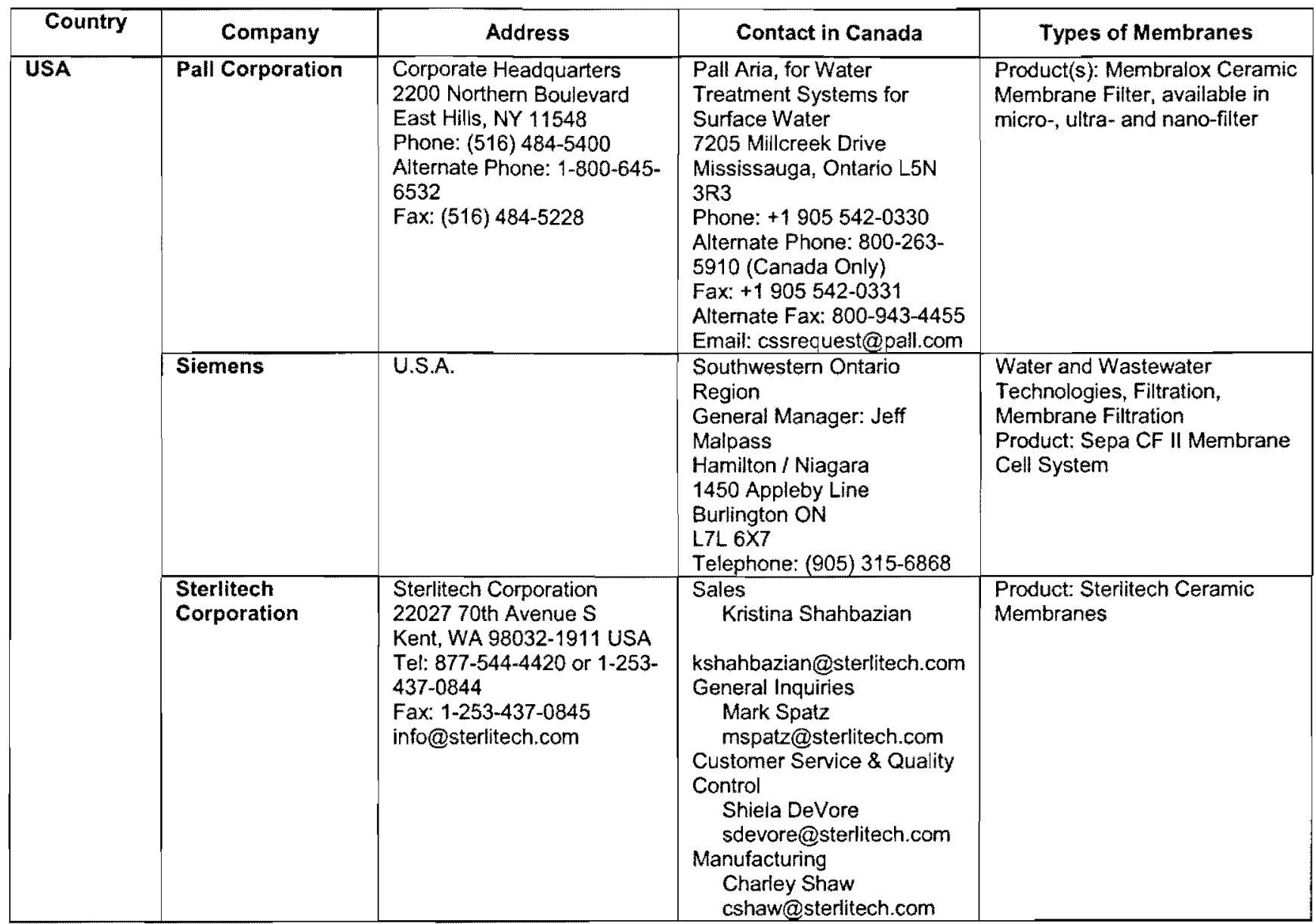




\section{Ultrasound Suppliers}

Table A.4. North American Distributors or Manufacturers of Ultrasonic Cleaning Technologies.

\begin{tabular}{|c|c|c|c|}
\hline Company & Type & $\begin{array}{l}\text { Frequency } \\
\text { Ranges }\end{array}$ & Cost \\
\hline $\begin{array}{l}\text { Branson Ultrasonics Corporation } \\
41 \text { Eagle Rd. P.O. Box } 1961 \\
\text { Danbury, CT } 06813-1961 \\
\text { Tel: (203) 796-0400 } \\
\text { Fax: (203) 796-0450 } \\
\text { E-mail: info(Obransonultrasonics.com }\end{array}$ & $\begin{array}{l}\text { Sonifier } \\
\text { FC (side or bottom mounted), } \\
\text { EB (tank bottom), CB (side- } \\
\text { mounting) }\end{array}$ & $\begin{array}{l}25 \mathrm{kHz} \\
40 \mathrm{kHz} \\
80 \mathrm{kHz} \\
120 \mathrm{kHz} \\
170 \mathrm{kHz}\end{array}$ & $\mathrm{n} / \mathrm{a}$ \\
\hline $\begin{array}{l}\text { APC International, Ltd. } \\
\text { Duck Run, P.O. Box } 180 \\
\text { Mackeyville, PA } 17750 \text { USA } \\
\text { Tel: (+) 1-570-726 } 6961 \\
\text { Fax: (+) 1-570-726-7466 } \\
\text { E-mail: sales@Qmericanpiezo.com }\end{array}$ & $\begin{array}{l}\text { Ultrasonic Cleaning Transducers } \\
\text { and Generator }\end{array}$ & $\begin{array}{l}25 \mathrm{kHz} \\
28 \mathrm{kHz} \\
40 \mathrm{kHz} \\
80 \mathrm{kHz} \\
120 \mathrm{kHz}\end{array}$ & $\begin{array}{l}\text { na, but based on self- } \\
\text { made US devices, i.e. } \\
\text { each component parts } \\
\text { sold individually }\end{array}$ \\
\hline $\begin{array}{l}\text { Crest Ultrasonics Corp. } \\
\text { P.O. Box } 7266 \text { Scotch Road Trenton, NJ } 08628 \\
(1-800-992-7378)\end{array}$ & $\begin{array}{l}\text { Martin Walter Push-Pull } \\
\text { Transducers with } 1000 \mathrm{~W} \\
\text { gemerator }\end{array}$ & $\begin{array}{l}25,40 \text { or } 68 \overline{\mathrm{kHz}} \\
\text { frequencies }\end{array}$ & $\begin{array}{l}\text { (Push Pull transducer } \\
\text { at } 45 \mathrm{kHz} \text { is } \\
\$ \mathrm{CAD} 2,190, \\
\text { generator at } 1000 \mathrm{~W} \text { is } \\
2800 \mathrm{CAD} \text { ) } \\
\text { (the } 40 \mathrm{khz} \text { is } \\
\$ 3,800 \mathrm{CAD}, 132 \text { is } \\
\$ 30,000 \mathrm{CAD}, 192 \text { is } \\
\$ 45,000 \mathrm{CAD} \text { ) }\end{array}$ \\
\hline $\begin{array}{l}\text { Blackstone-NEY UItrasonics } \\
\text { Division of Cleaning Technologies Group, LLC. } \\
\text { P.O. Box } 220 \\
9 \text { N. Main St. } \\
\text { Jamestown, NY } 14702-0220 \\
\text { Toll-Free: (888) } 665-2340 \\
\text { Phone: (716) } 665-2340 \\
\text { Fax: (716) } 665-2480\end{array}$ & $\begin{array}{l}\text { multiSONIK, PROT- } 2.506 \text { Model } \\
\text { (Other models include: } \\
\text { multiSONK } 2 \text { ) }\end{array}$ & $\begin{array}{l}40,72 \mathrm{kHz} \\
104 \mathrm{kHz} \\
170 \mathrm{kHz} \\
40,80,120,140 \\
170,220 \text { and } 270 \\
\mathrm{kHz}\end{array}$ & $\begin{array}{l}\text { Single Frequency of } \\
60 \mathrm{kHz} \text { start at } \\
\$ 3,600 \text { US, Three } \\
\text { frequencies starting at } \\
6700 \text { US, four or more } \\
\text { frequencies starting at } \\
\$ 15,000 \mathrm{US}\end{array}$ \\
\hline $\begin{array}{l}\text { Misonix, Incorporated } \\
\quad \text { (formerly Heat Systems, Inc.) } \\
1938 \text { New Highway } \\
\text { Farmingdale, New York } 11735 \\
\text { Phone: 631-694-9555, 800-645-9846 } \\
\text { FAX: } 631-694-9412\end{array}$ & Sonicator $/$ Microson ${ }^{1 / 4}$ & - & $\cdots$ \\
\hline $\begin{array}{l}\text { Sonics \& Materials, Inc. } \\
53 \text { Church Hill Road } \\
\text { Newtown, Connecticut } 06470 \\
\text { Phone: } 203-270-4600,800-745-1105 \\
\text { FAX: 203-270-461 }\end{array}$ & Vibra-Cell & - & $-\infty$ \\
\hline $\begin{array}{l}\text { Sonaer Inc. } \\
\text { 145 Rome Street } \\
\text { Farmingdale, New York } 11735 \\
\text { Phone: } 631-756-4780 \\
\text { FAX: } 631-756-4775\end{array}$ & $\begin{array}{l}\text { SONOZAP } \\
\text { Ultrasonic Processors, Atomizer } \\
\text { Nozzles, and Nebulizers }\end{array}$ & - & - \\
\hline
\end{tabular}




\section{Appendix B}

Particle size distribution of the aqueous solution containing precipitate, using the Malvern Mastersizer 2000 analyzer.

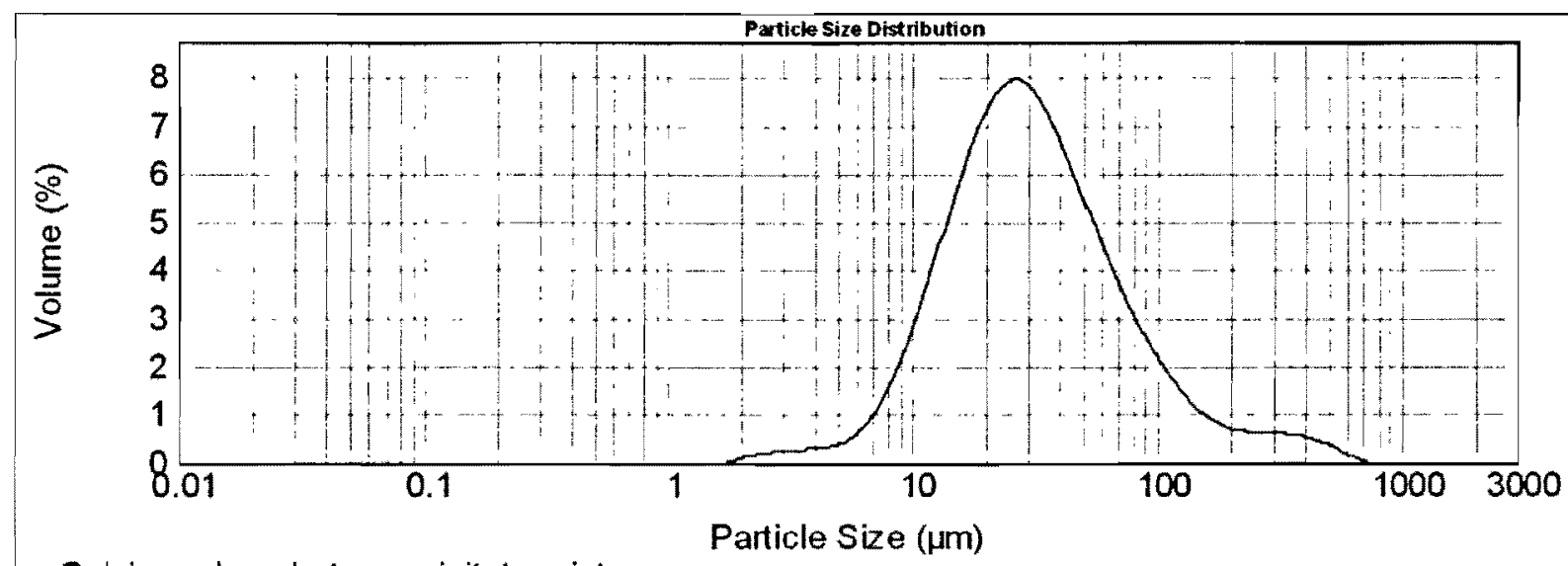

Calcium phosphate precipitate mixture

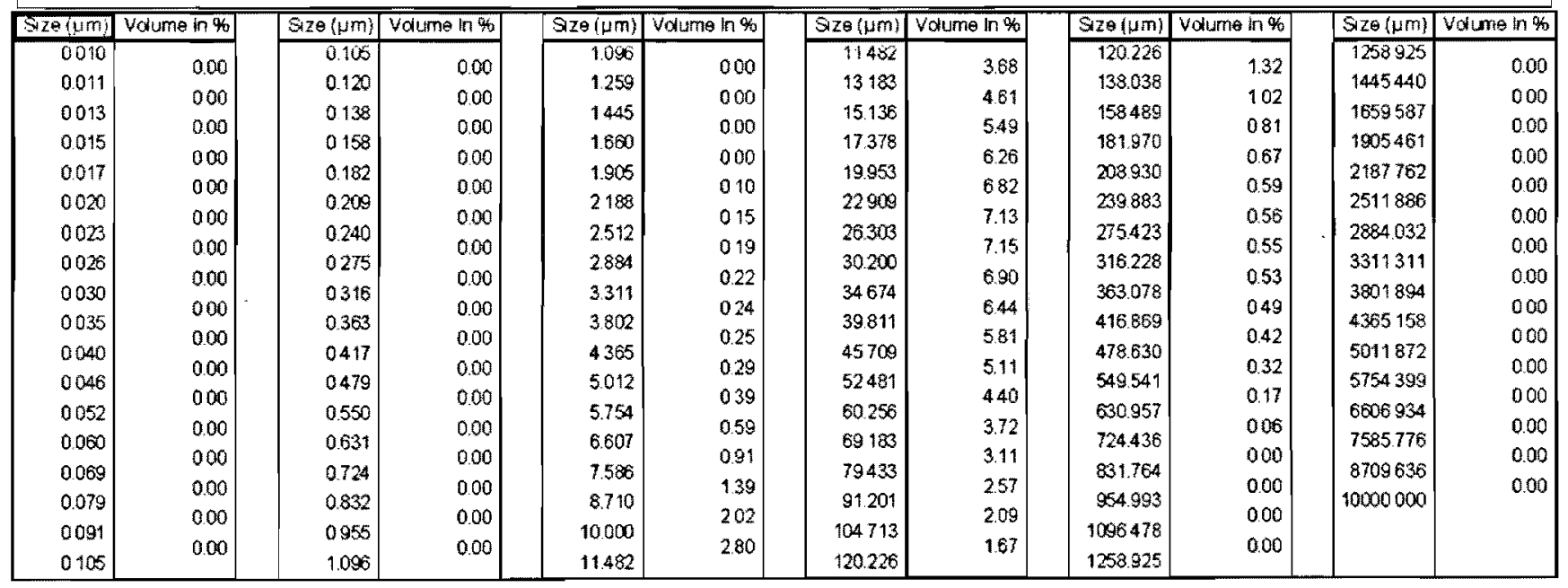




\section{Appendix C}

Pore size of the membrane fall under the ultrafiltration range shown by the green line in the figure below

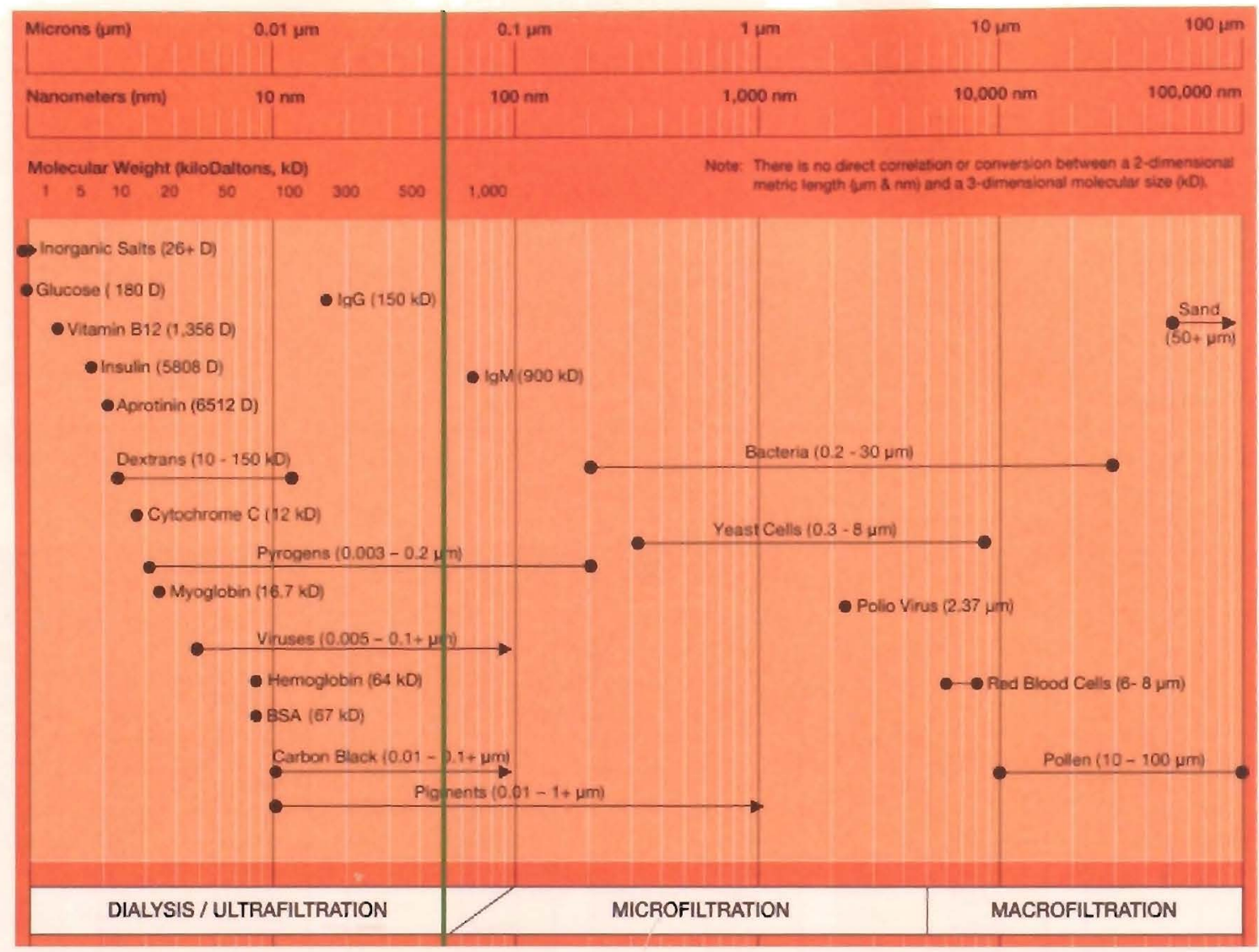

Figure C.1 Chart of membrane filtration removal capabilities based on pore size and constituent removal [source: http://www.spectrapor.com/dialysis/FAQ.html] 